\title{
Arbeidsmarktscanner Rijksuniversiteit Limburg afgestudeerden 1986-1989
}

Citation for published version (APA):

Ramaekers, G. W. M., \& Heijke, J. A. M. (1991). Arbeidsmarktscanner Rijksuniversiteit Limburg afgestudeerden 1986-1989. Researchcentrum voor Onderwijs en Arbeidsmarkt, Faculteit der Economische Wetenschappen. ROA Reports No. 6 https://doi.org/10.26481/umarep.1991006

Document status and date:

Published: 01/01/1991

DOI:

10.26481/umarep.1991006

Document Version:

Publisher's PDF, also known as Version of record

\section{Please check the document version of this publication:}

- A submitted manuscript is the version of the article upon submission and before peer-review. There can be important differences between the submitted version and the official published version of record.

People interested in the research are advised to contact the author for the final version of the publication, or visit the DOI to the publisher's website.

- The final author version and the galley proof are versions of the publication after peer review.

- The final published version features the final layout of the paper including the volume, issue and page numbers.

Link to publication

\footnotetext{
General rights rights.

- You may freely distribute the URL identifying the publication in the public portal. please follow below link for the End User Agreement:

www.umlib.nl/taverne-license

Take down policy

If you believe that this document breaches copyright please contact us at:

repository@maastrichtuniversity.nl

providing details and we will investigate your claim.
}

Copyright and moral rights for the publications made accessible in the public portal are retained by the authors and/or other copyright owners and it is a condition of accessing publications that users recognise and abide by the legal requirements associated with these

- Users may download and print one copy of any publication from the public portal for the purpose of private study or research.

- You may not further distribute the material or use it for any profit-making activity or commercial gain

If the publication is distributed under the terms of Article $25 \mathrm{fa}$ of the Dutch Copyright Act, indicated by the "Taverne" license above, 


\section{ARBEIDSMARKTSCANNER RIJKSUNIVERSITEIT LIMBURG \\ AFGESTUDEERDEN 1986 - 1989}

ROA-R-1991/6

G.W.M. Ramaekers

J.A.M. Heijke

RESEARCHCENTRUM VOOR ONDERWIJS EN ARBEIDSMARKT

Faculteit der Economische Wetenschappen

Rijksuniversiteit Limburg

Maastricht, september 1991 


\section{CIP-GEGEVENS KONINKLIJKE BIBLIOTHEEK, DEN HAAG}

Ramaekers, G.W.M.

Arbeidsmarktscanner Rijksuniversiteit Limburg: afgestudeerden 1986-1989/G.W.M. Ramaekers, J.A.M. Heijke. - Maastricht: Researchcentrum voor Onderwijs en Arbeidsmarkt, Faculteit der Economische Wetenschappen, Rijksuniversiteit Limburg. - (Rapport/Researchcentrum voor Onderwijs en Arbeidsmarkt. ISSN 0922-8098; 1991/6)

Met lit. opg.

ISBN 90-5321-063-6 geb.

Trefw.: univeristair onderwijs en arbeidsmarkt; Maastricht; onderzoek. 
INHOUDSOPGAVE

1. INLEIDING

1.1. Ontwikkeling van de arbeidsmarktscanner 1

1.1.1. Achtergrond 1

1.1.2. Ontworpen in een pilotstudy in de gezondheidswetenschappen 3

1.1.3. Verder ontwikkeld aan de Rijksuniversiteit Limburg 3

1.1.4. Nog geen vergelijkbare gegevens 4

1.2. Relevantie en gebruiksmogelijkheden van de arbeidsmarktscanner 5

$\begin{array}{ll}\text { 1.3. Indeling van het rapport } & 7\end{array}$

2. INHOUD VAN DE ARBEIDSMARKTSCANNER 10

2.1. Benodigde gegevens 10

2.2. Systematiek 11

2.3. Vragenlijsten 12

3. TOEPASSING VAN DE ARBEIDSMARKTSCANNER 15

3.1. Schets van de Rijksuniversiteit Limburg 15

3.2. Verrichte metingen $\quad 17$

3.3. Dataverzameling en respons 19

4. KENMERKEN VAN DE RESPONDENTEN

4.1. Inleiding 21

4.2. Afstudeerjaar en gevolgde studie 22

4.3. Achtergrondkenmerken 25

4.4. Samenvatting $\quad 28$

5. INTREDE OP DE ARBEIDSMARKT 29

5.1. Het begrip arbeidsmarktpositie $\quad 29$

5.2. Verschuivingen in arbeidssituatie tijdens het eerste jaar na afstuderen 31

5.3. Intredewerkloosheid 32

5.4. Verwerving van de eerste baan $\quad 34$

5.5. Samenvatting $\quad 35$ 
6. MOBILITEIT

6.1. Inleiding $\quad 37$

6.2. Omvang van de mobiliteit 38

6.3. Bedrijfssector- en beroepsmobiliteit 39

6.4. Verandering in baanzekerheid en werktijdfactor $\quad 40$

6.5. Verandering van functie-niveau $\quad 42$

6.6. Verandering in de aansluiting met de gevolgde studie $\quad 44$

6.7. Samenvatting 45

7. KENMERKEN VAN DE HUIDIGE FUNCTIE

7.1. Inleiding $\quad 47$

7.2. Grootte en lokatie van de werkorganisatie 48

7.3. Branche en beroep $\quad 50$

7.3.1. Bedrijfstak en beroepssector $\quad 50$

7.3.2. Branche- en beroepenspreiding van RL-studierichtingen 51

$\begin{array}{ll}\text { 7.3.3. Beroep en bedrijfssubgroep } & 57\end{array}$

7.4. Niveau van de functie $\quad 60$

7.5. Later gevolgd onderwijs $\quad 69$

7.6. Samenvatting 71

8. HUIDIGE ARBEIDSSITUATIE

8.1. Inleiding 74

8.2. Participatie aan het arbeidsproces $\quad 74$

8.3. Zekerheid van de huidige baan en werktijdfactor $\quad 79$

8.4. Potentiële baanmobiliteit 82

8.5. Samenvatting 85

9. SAMENVATTING EN CONCLUSIES

9.1. Inleiding 87

9.2. Rijksuniversiteit Limburg 88

9.3. Faculteit der Geneeskunde 93

9.4. Faculteit der Gezondheidswetenschappen 95

9.5. Faculteit der Rechtsgeleerdheid 98

9.6. Faculteit der Economische Wetenschappen 101

9.7. Implicaties voor beleid 103 
BIJLAGE 1. TABELLEN

BIJLAGE 2. SCHATTING VAN DE DUUR VAN DE INTREDEWERKLOOSHEID

BIJLAGE 3. DUMMY-VARIABELEN

BIJLAGE 4. BASISVRAGENLIJST 



\section{VERANTWOORDING}

Het Researchcentrum voor Onderwijs en Arbeidsmarkt (ROA) heeft de arbeidsmarktscanner in de periode 1988-1989 ontwikkeld. Dit gebeurde in het kader van een pilotstudy in de gezondheidswetenschappen naar de mogelijkheden om de arbeidsmarktpositie en loopbanen van universitaire afgestudeerden in kaart te brengen. De arbeidsmarktscanner werd ontwikkeld in opdracht van het Directoraat-Generaal voor het Hoger Onderwijs en Wetenschappelijk Onderzoek van het Ministerie van Onderwijs en Wetenschappen. De systematiek van de arbeidsmarktscanner bestaat hieruit dat de oud-studenten circa één jaar na hun afstuderen met behulp van een basisvragenlijst worden bevraagd en vervolgens jaarlijks met een beperkte jaarkaart waarmee zij mutaties kunnen doorgeven.

In het najaar van 1988 verleende het College van Bestuur van de Rijksuniversiteit Limburg (RL) aan het ROA opdracht om de arbeidsmarktscanner te implementeren voor alle afgestudeerden van deze universiteit. De scanner moest periodiek informatie beschikbaar doen komen over de positie van de afgestudeerden op de arbeidsmarkt en het verloop van hun beroepscarrière. De eerste fase van de arbeidsmarktscanner is van start gegaan in januari 1989 voor de duur van twee jaar. Het onderhavige rapport doet verslag van de resultaten van deze fase.

De eerste fase hield in dat van het in de bovengenoemde pilotstudy ontwikkelde algemene onderzoekinstrument versies werden opgesteld die specifiek zijn toegesneden op de aan de RL aanwezige studierichtingen. De faculteitspecifieke versies werden getest in een proefenquête onder een beperkt aantal afgestudeerden van deze faculteiten en waar nodig bijgesteld.

In 1990 werden vervolgens vier jaargangen oud-studenten voor de eerste maal geënquêteerd. Het betrof een integrale schriftelijke enquête onder degenen die in de kalenderjaren 1986 tot en met 1989 zijn afgestudeerd. Hierbij werden de jaargangen 1986 tot en met de eerste helft van 1988 benaderd met een aangepaste basisvragenlijst waarbij de loopbaan retrospectief in kaart werd gebracht. Degenen die in de tweede helft van 1988 zijn afgestudeerd alsmede de lichting 1989 werden met behulp van de reguliere basisvragenlijst benaderd.

In het onderhavige onderzoekrapport wordt het ontwikkelde onderzoekinstrument gepresenteerd alsmede de resultaten van de tot nu verrichte integrale metingen onder degenen die in de kalenderjaren 1986 tot en met 1989 aan de RL zijn afgestudeerd. Met ingang van 1991 worden bovengenoemde vier jaargangen afgestudeerden jaarlijks integraal geënquêteerd met behulp van de jaarkaart waarmee zij eventuele mutaties kunnen doorgeven. Met ingang van datzelfde jaar zullen tevens elk jaar degenen die in het voorgaande kalenderjaar zijn afgestudeerd met behulp 
van de basisvragenlijst voor de eerste keer worden geënquêteerd. Op deze wijze zal ieder jaar een geactualiseerd databestand beschikbaar komen.

De projectleiding van het onderzoek was in handen van prof. dr. J.A.M. Heijke. De dagelijkse leiding en de uitvoering berustte bij drs. G.W.M. Ramaekers. Dr. R.K.W. van der Velden verleende als senioronderzoeker inhoudelijke ondersteuning aan het onderzoek. Verder werd aan het onderzoek meegewerkt door drs. Th.B.J. Beekman (schatting van de duur van de intredewerkloosheid), drs. B.J.H. Lodder (schatting probit modellen), J.M.J.A. Pisters (dataverzameling en -verwerking) en drs. M.H. Wieling (berekening spreidingsindicatoren).

Het onderzoekproject werd vanuit de RL begeleid door een commissie, die bij het afronden van dit rapport bestond uit de volgende personen:

Prof. dr. A.J. Boon, Faculteit der Gezondheidswetenschappen;

Dr. P.A.J. Bouhuijs, vakgroep Onderwijsontwikkeling en Onderwijsresearch;

Prof. dr. H.F.J.M. Crebolder, Faculteit der Geneeskunde;

Dr. E. Drenthe, dienst Instellingsstrategie, die medio 1991 C.A. van der Hucht als voorzitter opvolgde;

Prof. dr. J.D.P. Kasper, Faculteit der Economische Wetenschappen;

Prof. mr. N.H.M. Roos, Faculteit der Rechtsgeleerdheid;

Drs. J.J.M. van der Schaft, dienst Studentenzaken.

De begeleidingscommissie blijft, ook na afronding van dit rapport, fungeren als inhoudelijk klankbord voor het ROA ten behoeve van dit onderzoekproject, en als coördinatiepunt ten behoeve van de contacten met de faculteiten.

Met ingang van september 1991 is de dienst Studentenzaken (SZ) verantwoordelijk voor de administratieve aspecten van het project in het kader van het te entameren alumnibeleid van de RL. De onderzoeksmethodologische en -inhoudelijke verantwoordelijkheid blijft bij het ROA berusten. Op deze wijze wordt voorkomen dat een vermenging optreedt van onderzoek en beleid. Deze scheiding tussen enerzijds administratieve en beheersmatige aspecten en anderzijds onderzoeksmethodologische en -inhoudelijke aspecten van het onderzoekproject betekent in concreto dat de dienst Studentenzaken zorgt voor het voortdurend actualiseren van het adressenbestand van alle afgestudeerden, de mailing van de jaarlijkse enquêtes, het optimaliseren van de respons en de verwerking en het beheer van de administratieve gegevens. Het ROA is verantwoordelijk voor het jaarlijks bijstellen van de enquêteformulieren en bijbehorende aanbiedingsbrieven en adviseert SZ bij de dataverzameling. Het ROA zorgt verder voor het coderen, invoeren en verwerken van de onderzoeksgegevens, het beheer van het onderzoeksbestand, de analyses en de jaarlijkse algemene rapportage. 


\section{INLEIDING}

\subsection{Ontwikkeling van de arbeidsmarktscanner}

\subsubsection{Achtergrond ${ }^{1}$}

Bij het weer aantrekken van de Nederlandse economie in de loop van de jaren ' 80 moest worden geconstateerd dat een substantiële verlaging van de werkloosheid uitbleef. Het besef groeide dat de werkloosheid voor een deel wordt veroorzaakt door het niet goed op elkaar aansluiten van de opleidingsstructuur van het aanbod van arbeid en de opleidingsstructuur van de vraag. Deze gebrekkige aansluiting tussen het onderwijs en de arbeidsmarkt is onder meer het gevolg van het gegeven dat veranderingen in de opleidingsstructuur van de vraag aanzienlijk sneller verlopen dan de door de gemaakte opleidingskeuzen in het onderwijs veranderende opleidingsstructuur van de beroepsbevolking. De aansluitingsproblematiek brengt enkele gevolgen met zich mee die deze problematiek nog verder kunnen verergeren, zoals ${ }^{2}$ :

a. neerwaartse verdringing, waarbij lager opgeleiden uit bepaalde functies worden verdrongen doordat voor deze functies hogere opleidingseisen worden gesteld, vanwege de ruime beschikbaarheid van hoger gekwalificeerden op de arbeidsmarkt, hoewel de inhoud van deze functies niet is veranderd;

b. de vernietiging van human capital door langdurige werkloosheid;

c. de vertraagde doordringing van marktsignalen in het onderwijstraject.

Laatstgenoemde factor kan het optreden van varkenscycli tot gevolg hebben. De uitstroom uit het onderwijs kan nu eenmaal slechts met vertraging van enkele jaren reageren op signalen betreffende verschuivingen in de vraag naar bepaalde arbeidscategorieën. Deze signalen zijn bovendien niet altijd even duidelijk.

Om dergelijke imperfecties-veroorzakende processen tijdig te kunnen waarnemen en te volgen in de tijd dient kwantitatieve informatie over de ontwikkelingen op de arbeidsmarkt in relatie tot die in het onderwijs periodiek ter beschikking te komen. Deze informatie vormt een eerste vereiste voor beleidsmaatregelen ter bestrijding van imperfecties. Door de economische faculteit van de RL werd in het midden van de jaren tachtig, in overleg met het Ministerie van Onderwijs en Wetenschappen, het plan opgevat om een onderzoekinstituut daartoe op te zetten: het Researchcentrum voor Onderwijs en Arbeidsmarkt (ROA).

1. Van Dam, de Grip, Heijke (1990).

2. De Grip (1987). 
Het ROA is in de loop van 1986 van start gegaan met een onderzoekopdracht van het Ministerie van Onderwijs en Wetenschappen om een informatiesysteem voor onderwijs en arbeidsmarkt te ontwikkelen. Dit systeem moet kwantitatief onderbouwde prognoses voortbrengen die gebruikt kunnen worden in onder meer de studie- en beroepskeuzevoorlichting, de onderwijscapaciteitsplanning, het economisch structuurbeleid en het arbeidsmarkt- en scholingsbeleid van de overheid en het bedrijfsleven. Daarnaast moet het informatiesysteem ook zorg dragen voor een goede 'monitoring' van de actuele situatie op de arbeidsmarkt voor de diverse beroepsgroepen en opleidingscategorieën.

Een belangrijke voorwaarde voor het welslagen van een dergelijk informatiesysteem is echter de nauwkeurigheid van de data waarmee de econometrische prognosemodellen worden gevoed. Hoewel de Arbeidskrachtentelling, en zijn opvolger de Enquête Beroepsbevolking, van het Centraal Bureau voor de Statistiek (CBS) nuttige informatie geven, is deze informatiebron vanwege het steekproefkarakter ontoereikend om gefundeerde uitspraken te kunnen doen over de arbeidsmarktperspectieven op een relatief laag aggregatieniveau zoals bijvoorbeeld een bepaalde studierichting.

Om meer nauwkeurige data over de aansluiting tussen het onderwijs en de arbeidsmarkt te krijgen is door het ROA een inventarisatie gehouden van verricht 'follow-up' onderzoek onder afgestudeerden van Nederlandse universiteiten ${ }^{3}$. Daarbij is met name gezocht naar regelmatig beschikbaar komende informatie over de huidige positie die afgestudeerden innemen op de arbeidsmarkt. Uitgangspunt van deze inventarisatie was de vraag of de onderzoekresultaten zouden kunnen worden opgenomen in het informatiesysteem onderwijs-arbeidsmarkt. Daartoe moeten de gegevens aan een aantal criteria voldoen zoals representativiteit, actualiteit, regelmatige herhaling, toegankelijkheid en de mogelijkheid de gegevens te koppelen aan andere databestanden, om aldus onderlinge vergelijkingen mogelijk te maken. De resultaten van deze inventarisatie waren teleurstellend. Strikt genomen voldeed geen enkel onderzoek aan de gestelde criteria. In aansluiting op deze bevindingen werd in het desbetreffende werkdocument bepleit een gestandaardiseerde aanpak te volgen die aan de gestelde criteria zou voldoen. Aanknopingspunten voor een dergelijke aanpak konden worden gevonden in Groot Brittannië bij de Association of Graduate Careers Advisory Services en in ons land bij de Landbouw Universiteit Wageningen.

3. Van Dam, de Grip, Heijke (1988). 


\subsubsection{Ontworpen in een pilotstudy in de gezondheidswetenschappen}

Door middel van een pilotstudy die door het ROA, in opdracht van het Ministerie van Onderwijs en Wetenschappen, onder afgestudeerden van de Faculteit der Gezondheidswetenschappen (FdGW) van de RL werd verricht, kon de eerder bedoelde gestandaardiseerde methodiek worden ontwikkeld.

Het pilotonderzoek was vooral gericht op het ontwikkelen van een (standaard-) instrumentarium om de ontwikkelingen op de arbeidsmarkt voor academici op de voet te kunnen volgen (te 'scannen') en te voorspellen. De aanwezigheid van dit standaard-instrumentarium (de 'arbeidsmarktscanner') zou het verrichten van dergelijk onderzoek moeten bevorderen en een waarborg moeten vormen voor de onderlinge vergelijkbaarheid van de onderzoeksresultaten. Door regelmatige herhaling van het volgens de ontwikkelde methodiek uitgevoerde loopbaan- en arbeidsmarktonderzoek, en bij toepassing daarvan op de afgestudeerden van alle faculteiten, zou een statistische dataset ontstaan die bruikbaar is voor landelijke analyses en prognoses op het niveau van bijvoorbeeld studierichtingen.

Voor het in kaart brengen van de arbeidsmarktpositie en de loopbaanontwikkeling van afgestudeerden werden een zogeheten 'basiskaart' en een 'jaarkaart' ontwikkeld. Deze vragenkaarten werden o.a. voorzien van studierichtingspecifieke overzichten van branche- en beroepsgroepen, waaruit de betrokken respondent een voor hem of haar relevante keuze moet maken. De basiskaart zou aan iedere afgestudeerde circa én jaar na het afstuderen moeten worden toegezonden. Met deze kaart wordt beoogd een beeld te krijgen van de genoten opleiding en de eerste bestemming op de arbeidsmarkt. Vervolgens zou ieder jaar de jaarkaart moeten worden toegezonden. Met deze kaart wordt gevraagd naar eventuele aanvullende opleidingen en eventueel opgetreden veranderingen in de arbeidsmarktpositie. De opzet en inhoud van de vragenkaarten staan beschreven in hoofdstuk 2 van dit rapport.

\subsubsection{Verder ontwikkeld aan de Rijksuniversiteit Limburg}

In het 'Ontwikkelingsplan 1989-1992 Rijksuniversiteit Limburg' wordt vermeld dat de RL grote waarde hecht aan de afstemming van haar onderwijs op de eisen van de beroepspraktijk en de aansluiting van het onderwijs op de mogelijkheden van de arbeidsmarkt ${ }^{4}$. In verband daarmee heeft het College van Bestuur in het kader van het 'Profileringsfonds RL' eind 1988 aan het ROA opdracht verleend een systeem voor periodiek 'follow-up' onderzoek onder afgestudeerden

4. Rijksuniversiteit Limburg (1988), blz. 33. 
van de RL te implementeren. Het project 'Arbeidsmarktscanner Rijksuniversiteit Limburg' is van start gegaan in januari 1989.

In 1989 zijn de in de pilotstudy gezondheidswetenschappen ontworpen vragenkaarten besproken in de begeleidingscommissie van het project 'Arbeidsmarktscanner RL' en vervolgens bijgesteld. Van de bij de vragenkaarten behorende faculteitspecifieke overzichten van brancheen beroepsgroepen werden vervolgens versies opgesteld met betrekking tot de Faculteit der Geneeskunde (FdG), Faculteit der Rechtsgeleerdheid ( $F d R)$ en Faculteit der Economische Wetenschappen (FdEW). Deze overzichten zijn voor commentaar voorgelegd aan de desbetreffende facultaire leden van de begeleidingscommissie en bijgesteld.

In het najaar van 1989 werd de basisvragenkaart getest in een proefenquête onder een vijftigtal afgestudeerden van de RL en naar aanleiding hiervan veranderd in een basisvragenlijst. Hierover is verslag gedaan in de vorm van een ROA-Werkdocument ${ }^{5}$. De definitieve basisvragenlijst en de bijgestelde jaarkaart zijn in bijlage II van dat werkdocument opgenomen. Als voorbeeld zijn de versies met betrekking tot de FdEW gekozen.

In 1990 werden vier jaargangen afgestudeerden met behulp van de basisvragenlijst integraal benaderd. Hiervan wordt in het onderhavige onderzoekrapport verslag gedaan.

\subsubsection{Nog geen vergelijkbare gegevens}

De arbeidsmarktscanner beperkt zich vooralsnog tot de afgestudeerden van de RL. Hierdoor zijn er nog geen soortgelijke gegevens van andere universiteiten beschikbaar, waarmee de in dit rapport gepresenteerde resultaten kunnen worden vergeleken. De wel beschikbare landelijke gegevens van het CBS over de beroepsbevolking en van het Ministerie van Sociale Zaken en Werkgelegenheid (SZW) over de werkloosheid laten een vergelijking evenmin toe. De eerder genoemde Enquête Beroepsbevolking (EBB) van het CBS is te grof om uitspraken te doen op het niveau van een studierichting. De gegevens die door SZW worden verzameld met betrekking tot het bemiddelingsbestand zonder baan zijn niet alleen onvolledig maar ook in hoge mate vervuild. Het is daarom belangrijk dat de arbeidsmarktscanner ook aan andere universiteiten wordt toegepast.

5. Ramaekers en Heijke (1990-I). 


\subsection{Relevantie en gebruiksmogelijkheden van de arbeidsmarktscanner ${ }^{6}$}

Doel van de arbeidsmarktscanner is het systematisch en periodiek beschikbaar doen komen van informatie over de positie van afgestudeerden op de arbeidsmarkt en het verloop van hun beroepscarrière. Deze informatie is voor diverse groepen van belang. Het zijn vooral de universiteiten alsmede de afgestudeerden en hun werkgevers die belang hebben bij de primaire onderzoekresultaten. Deze krijgen echter een aanzienlijke meerwaarde als dergelijk onderzoek regelmatig wordt herhaald en de resultaten onderling kunnen worden vergeleken, waardoor de mogelijkheid ontstaat om trendextrapolaties en prognoses op het niveau van studie/afstudeerrichtingen te verrichten. De primaire onderzoekgegevens die via de arbeidsmarktscanner worden verkregen en de op basis daarvan verrichte analyses en prognoses kunnen, in combinatie met andere bronnen, een bijdrage leveren aan onder meer de studie- en beroepskeuze, de arbeidsbemiddeling, de personeelsplanning, de capaciteitsplanning van het onderwijs, de opzet en inrichting van curricula, alsmede de kwaliteitsbewaking van het onderwijs.

Kiezers van een studie of beroep en degenen met een voorlichtende of bemiddelende taak hierbij, hebben behoefte aan informatie over de (toekomstige) kansen op werk, de (toekomstige) beroepsmogelijkheden, het te verwerven inkomen en de carrièremogelijkheden na het volgen van de verschillende opleidingen. De overheid heeft belang bij informatie over (en prognoses van) de arbeidsmarktpositie van academici aangezien zij, als bekostiger van het hoger onderwijs en verantwoordelijke voor het arbeidsvoorzieningenbeleid, het tot haar taak rekent om zorg te dragen voor een optimale aansluiting tussen vraag en aanbod op de arbeidsmarkt. Werkgevers, waartoe ook de overheid behoort, hebben voor de realisering van een doelmatige personeelsopbouw behoefte aan informatie over de (toekomstige) uitstroom uit de verschillende opleidingen en de mogelijkheden van deze opleidingen tijdens de beroepsuitoefening. Voor universiteiten en daarbinnen voor faculteiten zijn arbeidsmarktgegevens over hun opleidingen van belang voor de inrichting en kwaliteitsbewaking van het onderwijs en voor de interne voorlichting aan studenten over stageplaatsen en aan afstudeerders over mogelijke werkgevers. Capaciteitsplanners in het onderwijs hebben informatie nodig waarmee de capaciteit van de verschillende opleidingen beter kan worden afgestemd op de opnamemogelijkheden van de arbeidsmarkt en daarmee op de te verwachten opleidingsinstroom. Hun informatiebehoefte betreft met name gegevens over de omvang en samenstelling van de toekomstige uitstroom uit de diverse opleidingen en de vraag op de arbeidsmarkt naar deze opleidingen. Onderwijsgevenden en ontwerpers van curricula hebben vooral behoefte aan informatie waarmee zij het onderwijs inhoudelijk kunnen evalueren in het licht van de eisen die de beroepspraktijk stelt. Het gaat hierbij om kwalitatieve informatie over de functie-uitoefening en de daarvoor benodigde kennis

6. Van Dam, Heijke, Ramaekers (1990). 
en vaardigheden. Voor dit doel kan de jaarlijkse bevraging, die sterk is gericht op het in beeld brengen van de arbeidsmarktpositie en de loopbaanontwikkeling, meerjaarlijks worden aangevuld met specifieke vragen betreffende de aansluiting tussen de opleiding en de beroepsuitoefening.

In het kader van de kwaliteitsbewaking van het wO wordt een toenemend belang toegekend aan actuele informatie over onder meer de arbeidsmarktpositie van de afgestudeerden. In het Hoger Onderwijs en Onderzoek Plan uit 1988 wordt ten behoeve van de kwaliteitsbewaking van het hoger onderwijs een belangrijke plaats toegekend aan de instellingen zelf. Dit is in een protocol voor de kwaliteitszorg, vastgesteld in het Bestuurlijk Overleg van de Vereniging van Samenwerkende Nederlandse Universiteiten van 4 november 1988, verder uitgewerkt. Onder 'externe kwaliteitszorg' wordt de kwaliteitsbeoordeling van het onderwijs door externe visitatiecommissies verstaan. Deze externe commissies zouden onder meer op basis van een zogeheten 'zelfstudie' door de betreffende faculteit een oordeel over de kwaliteit van het onderwijs moeten geven. Volgens de aanwijzingen voor de inhoud van deze zelfstudie dient in de rapportage ook aandacht te worden geschonken aan de afgestudeerden. De volgende punten zouden volgens het opgestelde protocol aan de orde kunnen komen met betrekking tot de afgestudeerden ${ }^{7}$ :

- Worden er vanuit het afnemende veld eisen geformuleerd waaraan de afgestudeerde moet voldoen?

- Is er sprake van duidelijke beroepsprofielen?

- Is daar in de loop der tijd wijziging in opgetreden?

- Waar komen de afgestudeerden terecht?

- Hoe staat het met de werkloosheid onder de afgestudeerden?

- Heeft men contacten met de alumni?

- Wat is de mening van de alumni over de opleiding?

- Zijn er structurele of incidentele contacten met het afnemende veld?

- Hoe is het beleid om de opleiding zo goed mogelijk op de arbeidsmarkt af te stemmen?

De arbeidsmarktscanner vormt een belangrijk hulpmiddel bij het beantwoorden van deze vragen.

Door middel van de arbeidsmarktscanner komen niet alleen periodiek actuele onderzoeksgegevens, die op de hiervoor genoemde gebieden kunnen worden toegepast, ter beschikking, maar ook een geactualiseerd adressenbestand van oud-studenten en hun werkgevers. Deze output kan te zijner tijd de basis vormen voor een scala aan activiteiten met betrekking tot de alumni, zoals het doelgroep-gericht aanbieden van post-academisch onderwijs, fundraising, het

7. In: Van Dam, Heijke, Ramaekers (1990). 
uitgeven van een magazine voor oud-studenten, profilering van de universiteit met betrekking tot onderwijs en onderzoek, het verwerven van derde-geldstroomonderzoeksopdrachten, etcetera. Tabel 1 in bijlage I geeft een overzicht van de belangstelling van de zijde van alumni voor dergelijke activiteiten.

\subsection{Indeling van het rapport}

Voorafgaand aan de presentatie van de onderzoekresultaten, wordt in hoofdstuk 2 de arbeidsmarktscanner beschreven waarmee gedetailleerde gegevens over de arbeidsmarktpositie en de beroepsloopbaan van universitaire afgestudeerden systematisch en periodiek worden gegenereerd. Eerst wordt ingegaan op de gegevens die worden verzameld en daarna volgt een beschrijving van de wijze waarop dit plaatsvindt.

Hoofdstuk 3 begint met een schets van de RL en behandelt vervolgens welke metingen met behulp van het onderzoekinstrument tot nu aan de RL zijn verricht, op welke wijze de dataverzameling heeft plaatsgevonden en wat de respons hierbij was.

In de daarop volgende hoofdstukken worden de onderzoekresultaten gepresenteerd met betrekking tot de vier jaargangen afgestudeerden die in 1990 voor de eerste keer zijn benaderd. De presentatie is opgebouwd volgens schema 1 . In hoofdstuk 4 wordt een algemene karakteristiek van de oud-studenten gegeven. Hierin komen naast de gevolgde studie en het jaar van afstuderen ook enkele achtergrondkenmerken van de respondenten aan bod.

Hoofdstuk 5 behandelt de intrede op de arbeidsmarkt aan de hand van achtereenvolgens de tijd die men nodig heeft gehad om de eerste betaalde baan te vinden, de hieruit resulterende verschuivingen in arbeidssituatie gedurende het eerste jaar na afstuderen en de wijze waarop men de eerste baan heeft gevonden.

De mobiliteit op de arbeidsmarkt vormt het thema van hoofdstuk 6 . Aan bod komt of men van werkgever is veranderd en of men bij eenzelfde werkgever al eens naar een andere functie is overgestapt. Nagegaan wordt of mobiliteit is samengegaan met verandering van bedrijfssector en beroep. Ook wordt bekeken of mobiliteit heeft geleid tot een vaste aanstelling en full-time baan en welke verschuiving in functie-niveau en aansluiting met de gevolgde studie resulteert uit mobiliteit. Dergelijke verschuivingen worden zichtbaar gemaakt door de eerste baan na afstuderen te vergelijken met de huidige baan.

Hoofdstuk 7 gaat nader in op de betaalde functie die men thans vervult. De functies worden ge- 
$-8-$

typeerd aan de hand van de werkorganisaties waarin men terecht is gekomen, het beroep dat men uitoefent, het niveau van de functie die men thans vervult en de aansluiting van deze functie met de genoten opleiding.

De huidige arbeidsmarktsituatie komt in hoofdstuk 8 aan bod. Nagegaan wordt in welke mate de oud-studenten thans participeren aan het arbeidsproces. Door te kijken hoeveel van de betaald werkende oud-studenten op zoek zijn naar ander werk worden indicaties verkregen omtrent de potentiële baanmobiliteit.

In hoofdstuk 9 worden de belangrijkste onderzoekresultaten voor de RL als geheel en verbijzonderd naar faculteit samengevat en worden enkele implicaties voor beleid aangegeven. 
Schema 1. Verloop arbeidsmarktpositie afgestudeerden RL

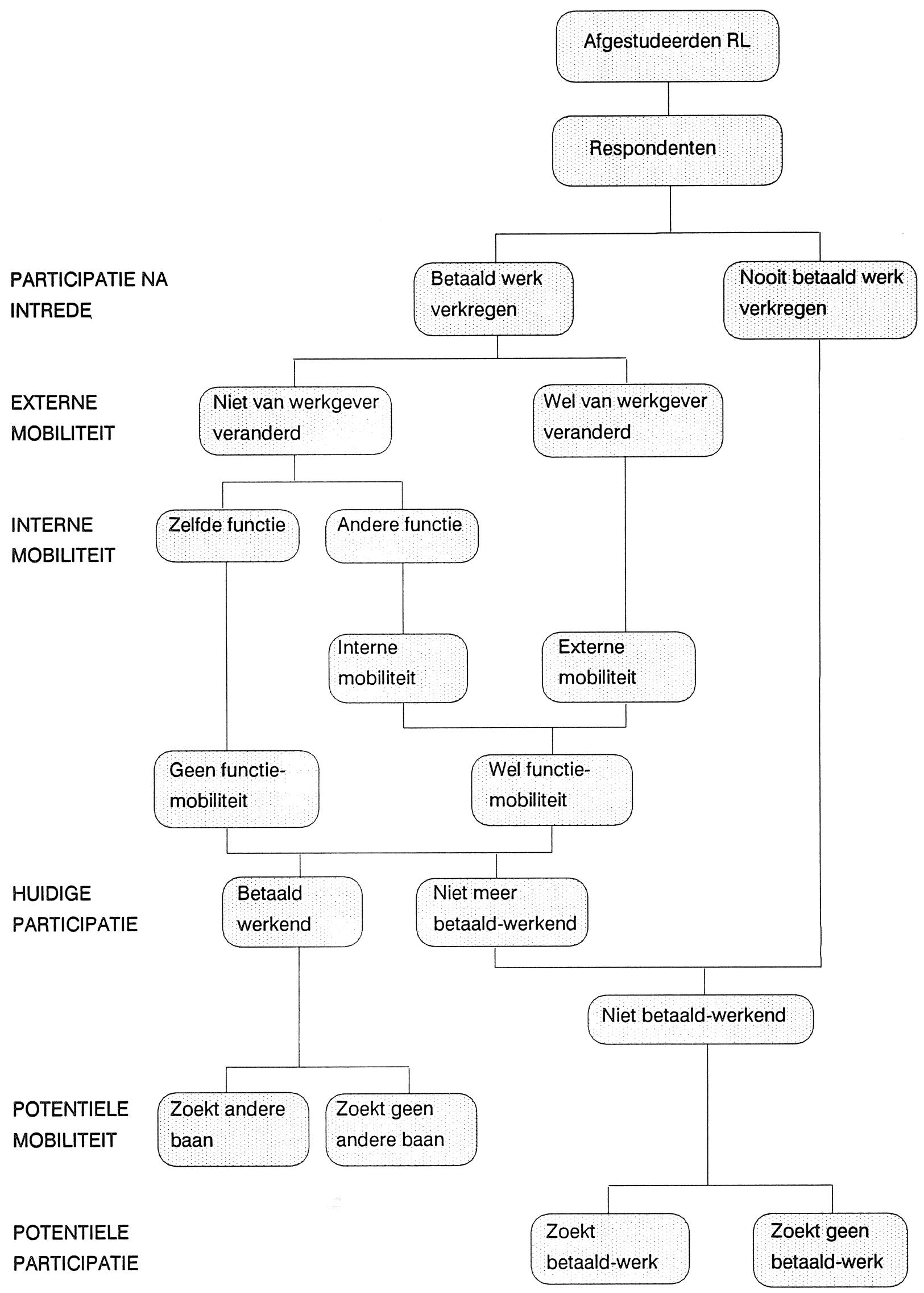




$$
\ldots
$$




\section{INHOUD VAN DE ARBEIDSMARKTSCANNER}

\subsection{Benodigde gegevens}

Om in de in paragraaf 1.2 genoemde informatiebehoefte te kunnen voorzien, zijn onder meer gegevens nodig over:

1. de kansen op werk na het verlaten van de opleiding, in het bijzonder in de beroependomeinen waarop de desbetreffende opleidingen beogen aan te sluiten;

2. het te verwerven inkomen en de carrièremogelijkheden in deze beroependomeinen;

3. de doelmatigheid van de opleiding in relatie tot de eisen die de beroepsuitoefening stelt.

Bovengenoemde gegevens worden in het kader van de arbeidsmarktscanner verzameld middels een systematische, periodieke peiling onder de afgestudeerden. Deze peiling bestaat uit een jaarlijkse schriftelijke bevraging van de alumni met betrekking tot hun positie op de arbeidsmarkt en de daarin opgetreden veranderingen (de bij 1 en 2 genoemde gegevens). De jaarlijkse bevraging kan meerjaarlijks worden aangevuld met additionele vragen over het verloop van de beroepscarrière en de rol hierbij van het genoten onderwijs (de bij 3 genoemde gegevens). In paragraaf 2.2 wordt verder op de systematiek van de arbeidsmarktscanner ingegaan en in paragraaf 2.3 worden de daarbij gebruikte vragenlijsten besproken.

Met behulp van de eerste bevraging na het afstuderen worden kerngegevens verzameld over:

- het 'onderwijsverleden' van de afgestudeerde, in het bijzonder over de laatstgevolgde studie- en afstudeerrichting(en);

- de 'eerste bestemming' na het afronden van de opleiding, dat wil zeggen de belangrijkste soort bezigheden die de afgestudeerde circa éen jaar na het afronden van de studie verricht.

Vervolgens indien men werkzaam is:

- de functie waarin men werkzaam is;

- de aansluiting van de functie op de gevolgde studie;

- de werkgever waarvoor men werkzaam is;

- de wijze waarop men in contact is gekomen met de huidige werkgever en de aard van de arbeidsovereenkomst;

- de arbeidsvoorwaarden;

- eventuele aanvullende opleidingen.

En indien men werkloos is:

- eventuele aanvullende opleidingen. 
Met behulp van de jaarlijkse peilingen die volgen op de eerste bevraging na het afstuderen, worden de veranderingen in deze kerngegevens tijdens de beroepsloopbaan vastgesteld.

\subsection{Systematiek}

De oud-studenten worden circa één jaar na hun afstuderen met behulp van een basisvragenlijst bevraagd en vervolgens jaarlijks benaderd met een beperkte jaarkaart waarmee zij mutaties kunnen doorgeven. De jaarkaart is een verkorte versie van de basisvragenlijst. In laatstgenoemde vragenlijst is nog een aantal vragen opgenomen die voornamelijk betrekking hebben op de gevolgde studie. Op beide kaarten staat al een aantal antwoorden voorgedrukt. Op de basisvragenlijst zijn dat gegevens die door de dienst Studentenzaken zijn verstrekt. Op de jaarkaart staan de antwoorden voorgedrukt die in het voorgaande jaar door de respondenten zijn gegeven. Aan de geënquêteerden wordt verzocht om onvolledige of gewijzigde gegevens aan te vullen of te corrigeren.

Beide kaarten zijn ontworpen in het kader van een pilotstudy naar de mogelijkheden om de arbeidsmarktpositie en loopbanen van afgestudeerden in de gezondheidswetenschappen in kaart te brengen ${ }^{8}$. Bij de constructie van de vragenlijsten gold als uitgangspunt dat hiermee data moeten kunnen worden voortgebracht die met andere gegevensbronnen zijn te vergelijken. Dit impliceert dat deze data op een methodisch verantwoorde wijze moeten worden verzameld en moeten aansluiten op (inter)nationaal gehanteerde definities van begrippen als werkloosheid en werkgelegenheid, en op (inter)nationale classificaties van bijvoorbeeld opleiding, beroep en bedrijfstak. Om aan deze vereisten tegemoet te kunnen komen is bij de pilotstudy een aantal veelgebruikte vragenlijsten geanalyseerd. Genoemd kunnen worden de vragenlijst van de Enquête Beroepsbevolking (EBB) van het $\mathrm{CBS}$ en de vragenlijsten die worden gebruikt bij de loopbaanonderzoeken van de Stichting Maatschappelijke Plaats Wageningse Afgestudeerden (MPW). Voor de samenstelling van de classificaties is gebruik gemaakt van de standaardindelingen van het CBS.

Zoals eerder is opgemerkt, kan de jaarlijkse bevraging periodiek, bijvoorbeeld vijfjaarlijks, worden aangevuld met meer gedetailleerde vragen over de beroepsmobiliteit, het verdere verloop van de beroepscarrière en eventuele andere thema's betreffende de aansluiting tussen onderwijs en arbeidsmarkt die men in deze vijfjaarlijkse bevraging aan de orde wil stellen.

8. Van Dam, Heijke en Ramaekers (1989). 


\subsection{Vragenlijsten}

In aansluiting op de in paragraaf 2.1 genoemde te verzamelen kerngegevens, en na bestudering van de in paragraaf 2.2 genoemde vragenlijsten, is besloten tot de volgende opbouw van zowel de basisvragenlijst als de jaarkaart:

a. persoonsgegevens;

b. opleidingsgegevens (alleen in de basisvragenlijst);

c. huidige arbeidsmarktsituatie;

d. kenmerken van beroep en functie;

e. organisatiekenmerken;

f. activiteiten (indien niet betaald werkzaam) en aanvullende opleidingen.

ad. a: Hier worden achtereenvolgens naam, voorletters, adres, postcode, woonplaats, land en telefoonnummer gevraagd. Het spreekt vanzelf dat de beschikbaarheid en de juistheid van deze gegevens een noodzakelijke voorwaarde vormen voor het welslagen van onderzoek onder afgestudeerden.

ad. b: In de basisvragenlijst is, in aansluiting op de hierboven genoemde persoonsgegevens, een aantal vragen opgenomen over de persoonsgegevens geboortejaar en geslacht, de vooropleiding, de reeds aanwezige werkervaring op het moment van afstuderen en de belangrijkste bezigheden, in elke maand, tussen het moment van afstuderen en het moment van enquêteren. Verder bevat dit vragenblok vragen over de gevolgde studie- en afstudeerrichting(-en) en de datum van voltooiing van de studie. Al deze gegevens zijn, met uitzondering van de reeds aanwezige werkervaring op het moment van afstuderen en de vraag naar de bezigheden na het afstuderen, bekend bij de administratie van de dienst Studentenzaken. De vragen over de voltooide studie- en afstudeerrichting zijn gesloten. De antwoorden zijn gecodeerd aan de hand van een indeling die is gebaseerd op de Standaard Onderwijs Indeling (SOI) van het CBS. Uiteraard is onderscheid gemaakt tussen de verschillende afstudeerrichtingen, hetgeen binnen de SOI niet wordt gedaan. Daarvoor is een zesde positie toegevoegd aan de SOI-codes.

ad. c: De huidige arbeidsmarktsituatie verwijst naar de belangrijkste dagelijkse werkzaamheden die door de respondent worden verricht. Dit om vast te stellen of iemand behoort tot de werkzame beroepsbevolking, zoals die door de International Labour Organisation (ILO) wordt gedefinieerd. De hiervoor gestelde vraag is rechtstreeks overgenomen uit de vragenlijst voor de Enquête Beroepsbevolking van het CBS (In zoverre dat in de EBB gevraagd wordt of iemand één of meer uren in loondienst werkzaam is. Indien dit het 
geval is wordt hij of zij gerekend tot de werkzame beroepsbevolking. In onze vragenlijsten wordt gevraagd naar de situatie die de dagelijkse bezigheden het beste weergeeft) ${ }^{9}$.

ad. d: In het vragenblok over de kenmerken van de betaalde functie wordt gevraagd of men in het afgelopen jaar van functie of werkgever is veranderd, op welke wijze men de huidige functie heeft verkregen, wat de aard en de tijdsduur van de huidige aanstelling is en tot welke (voorgecodeerde) beroepsgroepen men behoort. Ter controle hierop is tevens een open vraag opgenomen over de functienaam. De bijgevoegde op de desbetreffende faculteit afgestemde lijst met benamingen van de beroepsgroepen met de bijbehorende codes is afgeleid uit de beroepenclassificatie die door het CBS wordt gehanteerd. Tot dit vragenblok behoren tevens vragen over de mate waarin men leiding moet geven en de hoogte van het bruto maandinkomen. Daarnaast worden drie vragen gesteld die betrekking hebben op de aansluiting van de functie op de gevolgde studie:

- Een vraag of het gaat om de uitoefening van een reeds bestaande functie danwel om een nieuwe functie. Dit om vast te stellen of aanbod van nieuwe opleidingen naar vorm (Probleem Gestuurd Onderwijs) en/of inhoud (bijvoorbeeld gezondheidswetenschappen) leidt tot nieuwsoortige vraag.

- Een vraag betreffende de voor de uitoefening van de functie vereiste opleiding. Dit om de concurrentiegevoeligheid op de arbeidsmarkt van een opleiding vast te stellen, hetzij naar niveau van de opleiding, hetzij naar opleidingsrichting.

- Een vraag of de functie wordt uitgeoefend in het kader van een tweede fase opleiding of een post-doctorale beroepsopleiding.

ad. e: Tot het vragenblok over de kenmerken van de organisatie waarbij men werkzaam is, behoren vragen over de branche, de totale personeelsomvang, het soort produkt of dienst van de organisatie en het adres van de vestiging van het bedrijf of van de instelling waarbij men werkt. De respondenten wordt gevraagd om de branche-code aan te geven. Hiertoe is voor iedere faculteit een op de desbetreffende faculteit afgestemde lijst van bedrijfsgroepen opgesteld met de bijbehorende SBI-codes (Standaard BedrijfsIndeling) die door het CBS worden gehanteerd. De open vraag over het vestigingsadres wordt gesteld met het oog op het opbouwen van een adressenbestand van werkgevers.

ad. f: Aan de afgestudeerden wordt gevraagd of men op zoek is naar betaald werk en of men daar dan binnen twee weken aan zou kunnen beginnen. Deze vragen zijn opgenomen om te kunnen vaststellen of men (indien niet betaald werkzaam) overeenkomstig de ILO-de-

9. Het CBS overweegt om over te gaan naar twaalf of meer uren in loondienst per week. Indien dit gebeurt, zullen wij het CBS hierin volgen. 
$-14-$

finitie nog als werkzoekende, en dus behorend tot de beroepsbevolking, kan worden aangemerkt. Bovendien wordt gevraagd of men in het afgelopen jaar een cursus of opleiding heeft gevolgd en zo ja wat de aard en richting daarvan was. 


$$
\ldots
$$




\section{TOEPASSING VAN DE ARBEIDSMARKTSCANNER}

\subsection{Schets van de Rijksuniversiteit Limburg}

De $R L$ is de jongste universiteit van Nederland. De instelling bestaat uit vijf faculteiten: geneeskunde, gezondheidswetenschappen, rechtsgeleerdheid, economische wetenschappen en algemene wetenschappen.

Faculteit der Geneeskunde (FdG)

Het onderwijs aan deze faculteit is gestart in september 1974. Het onderwijs is sterk geënt op actuele ontwikkelingen binnen de gezondheidszorg. Het accent ligt op de eerstelijns gezondheidszorg. Evenals bij andere medische faculteiten het geval is volgen de studenten eerst de vierjarige opleiding tot het doctoraalexamen en vervolgens de tweejarige opleiding tot basisarts. De opleiding kan worden voortgezet in een post-basisartsopleiding voor medisch specialist (waaronder die voor huisarts en sociaal-geneeskundige).

Faculteit der Gezondheidswetenschappen (FdGW)

In september 1980 is het onderwijs in de studierichting sociale gezondheidkunde gestart met drie afstudeermogelijkheden:

- beleid en beheer van gezondheidszorgvoorzieningen (BB);

- gezondheidsvoorlichting en -opvoeding (GVO);

- verplegingswetenschap (VW).

In 1984 werd het aantal afstudeerrichtingen met vier uitgebreid en ging de studierichting sociale gezondheidkunde verder onder de naam gezondheidswetenschappen. De vier nieuwe afstudeerrichtingen waren:

- bewegingswetenschappen (BW);

- biologische gezondheidkunde (BGK);

- filosofie en theorie der gezondheidswetenschappen (FT);

- geestelijke gezondheidkunde (GGK).

Met de zeven afstudeermogelijkheden beschikt de FdGW over een breed scala van opleidingen, waarbij een inhoudelijke verbinding wordt gelegd tussen gamma- en bèta-disciplines. Dit maakt gezondheidswetenschappen tot een in Nederland unieke studierichting. 
Faculteit der Rechtsgeleerdheid (FdR)

Vanaf de start van het onderwijs in september 1982 verzorgt de FdR de afstudeerrichting Nederlands recht (zowel voltijds als in deeltijd) en vanaf september 1990 tevens de afstudeerrichting fiscaal recht. Het propaedeuse programma is voor beide afstudeerrichtingen gelijk.

\section{Faculteit der Economische Wetenschappen (FdEW)}

Het onderwijs aan deze faculteit is gestart in september 1984. De eerste fase opleiding economie bestaat uit een onderbouw van anderhalf jaar die voor alle studenten hetzelfde is. Daarna kunnen de studenten kiezen uit een vrij doctoraal en vier afstudeerrichtingen:

- algemene economie (AE);

- bedrijfseconomie (BE);

- kwantitatieve economie (KE);

- en vanaf februari 1988 internationaal management (IM).

\section{Faculteit der Algemene Wetenschappen (FdAW)}

Vanaf de officiële opening op 1 september 1987 zijn aan de FdAW twee taken toebedacht: dienstverlening ten behoeve van onderwijs en onderzoek van de andere faculteiten en bijdragen aan de uitbouw van de RL. De FdAW bestaat uit vier vakgroepen: wijsbegeerte, wiskunde, informatica en geschiedenis. Met ingang van september 1991 kan aan de FdAW de studierichting cultuur- en wetenschapsstudies worden gevolgd.

Het onderwijs aan de $\mathrm{RL}$ is probleemgestuurd van opzet. Het leer- en denkproces van de studenten wordt daarbij in gang gezet en gestimuleerd door theoretische problemen of problemen die afkomstig zijn uit het beroepsveld. De problemen zijn gegroepeerd rond thema's. Centraal staan het leren aanpakken van zulke problemen, het zelf opdoen van de benodigde kennis en het ondernemen van de benodigde leeractiviteiten. Dit gebeurt zowel individueel als groepsgewijs. Hierbij wordt in hoge mate een beroep gedaan op de zelfwerkzaamheid van de studenten. Vaardigheidstrainingen, bijvoorbeeld in computergebruik, maken naast theoretische vorming integraal deel uit van de verschillende onderwijsprogramma's. Tenslotte wordt in het onderwijs bijzondere aandacht besteed aan de ontwikkeling van de beroepsattitude.

De nog zeer recente ontwikkeling van het onderwijsaanbod van de $R L$ wordt weerspiegeld in de ontwikkeling van de instroom. Hiervan geeft tabel 1 een beeld. 
Tabel 1. Aantallen eerstejaarsstudenten aan de RL, 1983-1990

\begin{tabular}{lcccccccc}
\hline & 1983 & 1984 & 1985 & 1986 & 1987 & 1988 & 1989 & 1990 \\
\hline FdG & 162 & 153 & 147 & 150 & 150 & 150 & 152 & 153 \\
FdGW & 174 & 228 & 248 & 282 & 470 & 594 & 537 & 628 \\
FdR & 221 & 317 & 263 & 307 & 379 & 418 & 411 & 462 \\
FdEW & 101 & 151 & 189 & 362 & 455 & 516 & 531 \\
Totaal & 557 & 799 & 809 & 928 & 1361 & 1617 & 1616 & 1774 \\
\hline
\end{tabular}

Bron: Centrale Studentenadministratie RL

De instroom resulteert met vertraging in uitstroom. De minimale vertraging is gelijk aan de nominale studieduur, die voor basisartsen zes jaar bedraagt en voor de andere faculteiten vier jaar. Tabel 2 schetst de ontwikkeling van de omvang van de uitstroom.

Tabel 2. Aantallen afgestudeerden aan de RL, 1986 - 1989

\begin{tabular}{lrrrr}
\hline & 1986 & 1987 & 1988 & 1989 \\
\hline Basisartsen & 75 & 83 & 115 & 116 \\
Gezondheidswetenschappers & 92 & 122 & 127 & 141 \\
Juristen & 61 & -- & 165 & 127 \\
Economen & -- & 297 & 424 & 413 \\
Totaal & 228 & & & 29 \\
\hline
\end{tabular}

Bron: Centrale Studentenadministratie RL

\subsection{Verrichte metingen}

In 1990 zijn vier jaargangen oud-studenten integraal benaderd. Degenen die in de periode januari 1986 tot en met juni 1988 afstudeerden zijn benaderd met een aangepaste basisvragenlijst, waarbij de loopbaan retrospectief in beeld werd gebracht. Degenen die in de tweede helft van 1988 zijn afgestudeerd en de lichting 1989 zijn met een reguliere basisvragenlijst geënquêteerd. Deze vier jaargangen zijn in drie achtereenvolgende schriftelijke enquêtes benaderd:

1. Allen die in de tweede helft van het kalenderjaar 1988 afstudeerden zijn in april 1990 voor de eerste keer benaderd. Deze populatie is dus, afhankelijk van de maand waarin men is afgestudeerd, 15 tot 20 maanden na afstuderen voor de eerste keer geënquêteerd. Aangezien de meeste studenten in de maanden juli-september afstuderen, heeft deze enquête 
bij de meesten 15 tot 17 maanden na afstuderen plaats gevonden ${ }^{10}$.

2. Allen die in de kalenderjaren 1986, 1987 en in de eerste helft van 1988 zijn afgestudeerd, werden in augustus-september 1990 voor de eerste keer benaderd. Deze populatie is dus, afhankelijk van het jaar waarin men is afgestudeerd, pas na 2, 3, of 4 jaar voor de eerste keer geënquêteerd. Gezien de relatief lange tijdsduur tussen het moment van afstuderen en het moment van enquêteren, werd de basisvragenlijst ten behoeve van deze populatie eenmalig aangepast ${ }^{11}$. Zo wordt in de reguliere basisvragenlijst gevraagd naar een aantal kenmerken van de huidige betaalde functie. Besloten is om bij de vóór juli 1988 afgestudeerde oud-studenten niet alleen te vragen naar een aantal kenmerken van de huidige functie indien men momenteel betaald werk verricht, of van de laatste functie indien men thans niet langer betaald werkt, maar ook van de eerste betaalde functie na afstuderen. Een tweede aanpassing betrof de belangrijkste bezigheden in de periode tussen het moment van afstuderen en dat van enquêteren. Deze bezigheden zijn met behulp van een in kwartalen verdeelde tijdbalk gemeten. In de reguliere basisvragenlijst gebeurt dit met behulp van een tijdbalk die in maanden is verdeeld.

3. Allen die in het kalenderjaar 1989 afstudeerden zijn in november 1990 voor de eerste keer benaderd. Deze populatie is dus, afhankelijk van de maand waarin men is afgestudeerd, 11 tot 22 maanden na afstuderen voor de eerste keer geënquêteerd. Aangezien de meeste studenten in de maanden juli -september afstuderen, heeft deze enquête bij de meesten 14 tot 16 maanden na afstuderen plaats gevonden ${ }^{12}$.

In schema 2 zijn bovenbeschreven enquête-activiteiten samengevat.

Schema 2. Onderzoekactiviteiten in 1990

Onderzoekactiviteiten

Eerste enquêtering na afstuderen Interne rapportering aan CvB

Eerste enquêtering na afstuderen Interne rapportering aan CvB

Eerste enquêtering na afstuderen Interne rapportering aan CvB apr'90

jun'90
Afgestudeerden in de periode jan ' 86 - jun' 88

1989 jul - dec '88 
Zoals eerder is opgemerkt, worden de bovengenoemde vier jaargangen afgestudeerden met ingang van 1991 jaarlijks met behulp van de jaarkaart (waarmee zij eventuele mutaties kunnen doorgeven) integraal geënquêteerd. Het streven is er op gericht om deze jaarlijkse mutatieenquêtes steeds in oktober te houden. Door koppeling met de voorgaande datafiles zal een longitudinaal databestand beschikbaar komen. Hierdoor wordt het mogelijk om, naast dwarsdoorsneden van de arbeidsmarktpositie van afgestudeerden, ook ontwikkelingen in de loopbaan van academici te traceren. Bovendien kan de intrede op de arbeidsmarkt van nieuwe lichtingen afgestudeerden worden vergeleken met die van de oudere lichtingen. Immers elk jaar worden in september degenen die in het voorgaande kalenderjaar zijn afgestudeerd, met behulp van de basisvragenlijst voor de eerste keer geënquêteerd. Op deze wijze zal elk jaar een geactualiseerd databestand beschikbaar komen.

\subsection{Dataverzameling en respons}

Via de dienst Administratieve Organisatie/Administratieve Automatisering (AO/AA) van de RL zijn de namen, ouderlijke adressen en enkele persoons- en opleidingsgegevens (studentnummer, geslacht, geboortejaar, studierichting, afstudeerrichting van gezondheidswetenschappers en datum afstuderen) op floppy disk verkregen van alle studenten die in de kalenderjaren 1986 1989 aan de RL zijn afgestudeerd. Het gaat hierbij om in totaal 1362 oud-studenten. Deze afgestudeerden zijn als volgt over de faculteiten verdeeld.

Faculteit der Geneeskunde (FdG): $\quad 389$

Faculteit der Gezondheidswetenschappen (FdGW): $\quad 452$

Faculteit der Rechtsgeleerdheid (FdR): 475

Faculteit der Economische Wetenschappen (FdEW): $\quad 46$

Totaal RL: 1362

Aan elk van deze 1362 afgestudeerden is een al dan niet aangepaste basisvragenlijst met het bijbehorende faculteitspecifieke beroepen- en branche-overzicht gezonden. Op de lijst waren de persoonsgegevens reeds voorgedrukt aan de hand van gegevens uit het bestand van de dienst AO/AA. De basisvragenlijst en het bijbehorende overzicht van beroepen en branches waren vergezeld van een aanbiedingsbrief en een retourenveloppe waarmee de oud-studenten de ingevulde vragenlijst port-vrij konden retourneren. Deze mailing was gericht aan het ouderlijk adres. Met behulp van telefoonboeken kon een aantal gewijzigde ouderlijke adressen vóór de mailing worden achterhaald. Zowel het Bureau van de FdGW als de vereniging van afgestudeerde basisartsen van de RL stelde de hen bekende gewijzigde adressen van oud-studenten ter beschikking. In deze gevallen werd de mailing gericht aan het actuele adres van de oud-student en niet aan zijn of haar ouderlijk adres. Enkele weken later werd een tweede mailing gericht aan degenen 
die tot dan nog niet hadden gereageerd. Door middel van telefonisch contact na de tweede mailing kon een aantal oud-studenten worden bewogen alsnog hun medewerking aan het onderzoek te verlenen.

Het ondernemen van bovengenoemde activiteiten heeft tot 15 maart 1991 -toen een aanvang werd gemaakt met de analyse- geresulteerd in 1100 bruikbare retour ontvangen vragenlijsten, hetgeen neerkomt op een respons van $81 \%$. Hierbij dient te worden opgemerkt dat de uiteindelijke respons hoger kan uitvallen aangezien de activiteiten om de respons te maximaliseren continu worden voortgezet. Dit zal met name het geval zijn bij jaargang 1989 die als laatste is benaderd en waarbij de tijdsduur tussen de mailing en de start van de analyse het kortst is geweest (drie maanden). Het belang van een hoge respons is groot, niet alleen om bij de eerste meting een zo goed mogelijk beeld van de bestemming van de afgestudeerden te krijgen, maar vooral ook om een zo goed mogelijke uitgangspositie te hebben voor een bevredigende respons bij herhalingsmetingen.

Het is overigens de bedoeling om additioneel non-responsonderzoek te verrichten, in verband met mogelijke selectiviteit in de non-respons ten aanzien van de positie op de arbeidsmarkt. Dit zal telefonisch geschieden, waarbij tenminste gevraagd zal worden naar de bezigheden die men momenteel verricht.

De bevinding in paragraaf 8.2. dat zich onder de respondenten ook personen bevinden die geen betaalde arbeid verrichten (waaronder werklozen) wijst in ieder geval niet in de richting van een sterke selectiviteit in de non-respons ten aanzien van de positie op de arbeidsmarkt.

Een indicatie voor de mate waarin de onderzochte populatie representatief is voor de totale populatie kan worden verschaft door de verdeling naar afstudeerjaar, faculteit en geslacht. De representativiteit van de enquête zal aan bod komen bij de bespreking van deze kenmerken in hoofdstuk 4. 


\section{KENMERKEN VAN DE RESPONDENTEN}

\subsection{Inleiding}

Evenals bij andere groepen schoolverlaters het geval is, wordt de arbeidsmarktintrede van pas afgestudeerde academici sterk bepaald door de algemene situatie met betrekking tot de vraag naar en het aanbod van academici op de arbeidsmarkt. Binnen dit algemene kader werd de arbeidsmarktintrede van academici in de tweede helft van de tachtiger jaren in het bijzonder bepaald door twee ontwikkelingen. In de eerste plaats door de groei van het aantal universitair geschoolde instromers op de arbeidsmarkt. Deze trad juist in dié jaren versneld op als gevolg van de gelijktijdige uitstroom uit het WO van de laatste generaties 'oude-stijl' afgestudeerden en (vanaf 1986) van de eerste generaties 'eerste-fase' afgestudeerden. In de tweede plaats door de bezuinigingen in de kwartaire sector, de traditionele bron van werkgelegenheid voor academici. Het werd 'minder vanzelfsprekend dat academici een baan op academisch niveau, een vast contract met goede toekomstvooruitzichten en een hoog inkomen konden verwer$v^{\prime \prime 13}$. Hoewel alle afgestudeerden met deze situatie op de arbeidsmarkt worden geconfronteerd, slagen sommigen er in een betere arbeidsmarktpositie te verwerven dan anderen. Tegen de achtergrond van deze algemene arbeidsmarktsituatie voor academici, is in dit rapport getracht de arbeidsmarktpositie van de afgestudeerden van de $R L$ in beeld te brengen.

De gevolgde studierichting vormt de eerste invalshoek van waaruit de arbeidsmarktpositie inzichtelijk kan worden gemaakt. 'De werkloosheid onder universitaire afgestudeerden verschilt sterk naar studierichting. Daarmee is echter niet gezegd dat studierichting alleen en exclusief de arbeidsmarktpositie van een afgestudeerde vastlegt. Zo zijn ook individuele afgestudeerden uit studierichtingen met een slechte arbeidsmarktpositie succesvol terwijl, omgekeerd, ook afgestudeerden uit relatief succesvolle studierichtingen wel langdurig werkloos worden ${ }^{\prime 14}$. De verklaring van de verschillen in arbeidsmarktpositie die zich beperkt tot het aspect studierichting is onvolledig, omdat verschillende afstudeervarianten binnen een studierichting sterk verschillende arbeidsmarktposities kunnen hebben en de mate van succes op de arbeidsmarkt ook afhangt van een aantal individuele achtergrondkenmerken van de afgestudeerden.

In paragraaf 4.2. wordt beschreven in welk jaar de respondenten de arbeidsmarkt hebben betreden en welke studie men aan de RL heeft gevolgd. Vervolgens komt in paragraaf 4.3. een aantal achtergrondkenmerken van de respondenten aan bod. De in dit hoofdstuk beschreven

13. Van Nieuwenhuysen, Wielers (1990), blz. 6.

14. Van Nieuwenhuysen, Wielers (1990), blz. 7. 
kenmerken van de respondenten worden gebruikt bij het verklaren van hun arbeidsmarktpositie, die in de volgende hoofdstukken aan bod komt.

\subsection{Afstudeerjaar en gevolgde studie}

\section{Afstudeerjaar}

Zoals eerder is opgemerkt, bestaat de onderzoekspopulatie uit degenen die in de periode 1986 1989 zijn afgestudeerd. Gezien de recente start van het onderwijs in rechten, gezondheidswetenschappen en economie aan de RL, gaat het bij deze faculteiten dus om de eerste lichtingen afgestudeerden. Dit kan een vertekend beeld geven, omdat van de eerste lichtingen relatief veel afgestudeerden tijdens hun studie student-assistent zijn geweest en na afstuderen als Assistent in Opleiding aan de desbetreffende faculteit zijn gaan werken.

Tabel 3 geeft een overzicht van de aantallen afgestudeerden en de aantallen respondenten naar afstudeerjaar. De verdeling van de respondenten naar afstudeerjaar blijkt sterk overeen te komen met de verdeling van de populatie. Wel neemt de respons enigszins af naarmate men langer geleden is afgestudeerd. Hiervoor zijn twee verklaringen mogelijk. In de eerste plaats neemt de kans toe dat het bij de RL geregistreerde ouderlijke adres niet langer actueel is naarmate men langer geleden is afgestudeerd. Het is ook mogelijk dat de bereidheid om voor de eerste keer aan een dergelijke enquête mee te werken, is afgenomen naarmate de binding met de RL met het verstrijken van de tijd kleiner is geworden. Periodieke bevraging, te beginnen én jaar na afstuderen, en regelmatige terugkoppeling van de onderzoekresultaten, bijvoorbeeld via een magazine voor alumni, kan deze bereidheid in stand houden.

Tabel 3. Representativiteit van de enquêtes naar afstudeerjaar (stand van de respons op 15-3-1991)

\begin{tabular}{|c|c|c|c|c|c|}
\hline \multirow[t]{2}{*}{ Afstudeerjaar } & \multicolumn{2}{|c|}{ Afgestudeerden } & \multicolumn{2}{|c|}{ Respondenten } & \multirow{2}{*}{$\begin{array}{c}\text { Respons } \\
\%\end{array}$} \\
\hline & Abs & $\%$ & Abs & $\%$ & \\
\hline 1986 & 228 & 17 & 173 & 16 & 76 \\
\hline 1987 & 297 & 22 & 228 & 21 & 77 \\
\hline 1988 & 424 & 31 & 353 & 32 & 83 \\
\hline 1989 & 413 & 30 & 346 & 32 & 84 \\
\hline Totaal & 1362 & 100 & 1100 & 100 & 81 \\
\hline
\end{tabular}


Faculteit

Tabel 4 geeft een overzicht van de respons, verdeeld naar faculteit. Hierin komt naar voren dat de respons onder de oud-studenten van de FdR het laagst is. Met betrekking tot de relatief lage respons onder juristen zou de enquête een rol kunnen hebben gespeeld die eerder door prof. mr. N.H.M. Roos in het voorjaar van 1988 is verricht onder juristen die in de periode 1 juni 1985 tot 1 februari 1988 aan de RL, de RUG en de RUL zijn afgestudeerd. Bij het na circa 2,5 jaar opnieuw enquêteren zou immers enige mate van 'enquête-moeheid' kunnen zijn opgetreden die negatief heeft uitgewerkt op de respons onder de jaargangen 1986 en 1987 van deze faculteit. Dit blijkt echter niet het geval te zijn geweest. In tabel 2 in bijlage 1 komt naar voren dat de respons niet alleen onder déze twee jaargangen van de FdR relatief laag is geweest, maar ook onder de in 1988 afgestudeerde juristen.

Tabel 4. Representativiteit van de enquêtes naar faculteit (stand van de respons op 15-3-1991)

\begin{tabular}{lrrrrr}
\hline Faculteit & \multicolumn{2}{c}{$\begin{array}{c}\text { Afgestudeerden } \\
\text { Abs }\end{array}$} & $\begin{array}{c}\text { Respondenten } \\
\text { Abs }\end{array}$ & \multicolumn{2}{c}{$\begin{array}{c}\text { Respons } \\
\%\end{array}$} \\
\hline FdG & 389 & 29 & 330 & 30 & 85 \\
FdGW & 452 & 33 & 385 & 35 & 85 \\
FdR & 475 & 35 & 343 & 31 & 91 \\
FdEW & 46 & 3 & 42 & 4 & 81 \\
Totaal & 1362 & 100 & 1100 & 100 & 81 \\
\hline
\end{tabular}

Wat de verdeling naar faculteit betreft komt de onderzochte populatie als gevolg van de relatief lage respons onder de juristen niet volledig overeen met de totale populatie. De verdeling naar faculteit vormt uiteraard alleen een indicatie voor de representativiteit van de onderzochte populatie als geheel. Het zegt niets over de representativiteit van de afzonderlijke facultaire populaties. Een indicatie voor het laatste kan worden verschaft door na te gaan hoe de respectievelijke facultaire populaties zijn verdeeld naar afstudeerjaar. Hiervan geeft tabel 2 in bijlage 1 een beeld. Uit deze tabel blijkt dat -per faculteit- de onderzochte populatie sterk overeenkomt met de totale populatie.

\section{Afstudeerrichting}

Aangezien de FdG geen afstudeerrichtingen binnen de studierichting geneeskunde heeft en aan de FdR tot nu alleen studenten in Nederlands recht zijn afgestudeerd, wordt hier alleen voor 
oud-studenten van de FdGW en FdEW aangegeven in welke richtingen binnen respectievelijk gezondheidswetenschappen en economie men is afgestudeerd.

De FdGW beschikt over zeven afstudeervarianten binnen gezondheidswetenschappen. Ruim driekwart van de bevraagde gezondheidswetenschappers is in de drie oudste varianten afgestudeerd, namelijk beleid en beheer van gezondheidszorgvoorzieningen (BB), gezondheidsvoorlichting en -opvoeding (GVO) en verplegingswetenschap (VW). Van de geënquêteerde gezondheidswetenschappers studeerde $34 \%$ af in BB, $23 \%$ in GVO en $20 \%$ in VW. Wat aantallen afgestudeerden betreft zijn de vier jongste richtingen beduidend kleiner. Van de bevraagde gezondheidswetenschappers studeerde $8 \%$ af in bewegingswetenschappen, $7 \%$ in biologische gezondheidkunde, eveneens $7 \%$ in geestelijke gezondheidkunde en slechts $1 \%$ in filosofie en theorie der gezondheidswetenschappen.

De FdEW beschikt over een vrij doctoraaltracé en vier afstudeerrichtingen, namelijk bedrijfseconomie (BE), algemene economie (AE), kwantitatieve economie (KE) en internationaal management (IM). De overgrote meerderheid $(90 \%)$ van de bevraagde economen is in $B E$ afgestudeerd. Slechts $10 \%$ studeerde af in $\mathrm{AE}$. In de beide andere richtingen ( $\mathrm{KE}$ en IM) waren nog geen studenten afgestudeerd.

Wanneer men in meerdere studie/afstudeerrichtingen is afgestudeerd, beschikt men over meer oriëntatiemogelijkheden op de arbeidsmarkt dan wanneer men slechts in én richting is afgestudeerd. Het afstuderen in meer dan éen richting (dubbel afstuderen) komt over het geheel genomen slechts zeer weinig voor: van de geënquêteerde oud-studenten bleken er slechts 21 $(2 \%)$ in twee richtingen te zijn afgestudeerd. Afstuderen in meer dan twee richtingen komt helemaal niet voor.

Dubbel afstuderen komt wel bij economen naar verhouding veel voor. Tot de 21 dubbele afstudeerders behoorden, naast 8 gezondheidswetenschappers en 1 basisarts, niet minder dan 12 economen:

- van de 12 economen zijn er 8 in twee afstudeerrichtingen binnen economie afgestudeerd (dubbele afstudeerrichting), terwijl 4 economen eerder in BB zijn afgestudeerd (dubbele studierichting);

- de 8 gezondheidswetenschappers zijn allen in twee afstudeerrichtingen binnen gezondheidswetenschappen afgestudeerd (dubbele afstudeerrichting);

- de desbetreffende basisarts is eerder in BB afgestudeerd (dubbele studierichting).

Voor de in dit rapport gehanteerde indeling van de afgestudeerden naar faculteit, en binnen 
faculteit naar afstudeerrichting, is het laatste behaalde doctoraalexamen bepalend. Als men gelijktijdig in twee richtingen is afgestudeerd, wordt men ingedeeld in die richting welke het dichtst aansluit bij de eerste betaalde functie na afstuderen.

\subsection{Achtergrondkenmerken}

In deze paragraaf worden de respondenten beschreven aan de hand van een aantal achtergrondkenmerken. Met behulp van deze kenmerken wordt in het vervolg van het rapport gepoogd om de arbeidsmarktpositie van de verschillende studie/afstudeerrichtingen inzichtelijk te maken. Het gaat hierbij om de volgende achtergrondkenmerken: geslacht, leeftijd, vooropleiding, eventuele werkervaring en bestuurlijke ervaring vóór of tijdens de studie aan de RL.

Een wellicht voor de hand liggend kenmerk, de studieduur wordt in dit onderzoek niet meegenomen aangezien dit kenmerk afhankelijk is van de gevolgde opleiding voordat men aan de RL ging studeren ${ }^{15}$, de nominale studieduur van het aan de RL gevolgde curriculum in combinatie met het studietempo en het eventuele volgen van meer dan én studie- of afstudeerrichting.

\section{Geslacht}

Tot de achtergrondkenmerken die kunnen worden genoemd als verklarende factor voor individuele verschillen in arbeidsmarktpositie behoort in de eerste plaats het geslacht. 'Zo kan de ongelijke spreiding van mannen en vrouwen over de studierichtingen van invloed zijn op de arbeidsmarktpositie van studierichtingen. Geslacht kan, onafhankelijk van de studierichting, een eigen invloed hebben op de arbeidsmarktpositie door én een verschillende oriëntatie op de arbeidsmarkt van mannen en vrouwen én door mogelijke discriminatie op de arbeidsmarkt' ${ }^{16}$.

Bruyn-Hundt (1988) noemt een aantal kernpunten ten aanzien van de sexe-ongelijkheid op de arbeidsmarkt: "vrouwen ontbreken op de arbeidsmarkt omdat er kleine kinderen verzorgd moeten worden; zij werken vaker in deeltijd; de opleiding van vrouwen is minder beroepsgericht; vrouwen werken in 'vrouwenberoepen', waardoor zij geconcentreerd zijn in een geringer aantal beroepen en sectoren dan mannen; in hogere functieniveaus ontbreken vrouwen nagenoeg geheel; de werkloosheid onder vrouwen is hoger dan die onder mannen, vooral als rekening wordt gehouden met de 'verborgen' werkloosheid; vrouwen hebben een lager uurloon dan

15. Bijvoorbeeld HEAO'ers hoeven het eerste studiejaar economie niet te volgen.

16. Van Nieuwenhuysen, Wielers (1990), blz. 8-9. 
mannen; een deel van dit verschil kan niet door objectieve factoren zoals leeftijd, opleiding e.d. verklaard worden, maar moet worden toegeschreven aan discriminatie." Het ROA heeft onderzocht in hoeverre deze constateringen ook van toepassing zijn op dat deel van de arbeidsmarkt waar afgestudeerden van de RL actief zijn ${ }^{17}$.

Van de 1100 geënquêteerde oud-studenten van de RL blijkt meer dan de helft $(56 \%)$ uit vrouwen te bestaan. Het aandeel van vrouwen varieert sterk naar studierichting. Onder oudstudenten van de FdGW is het aandeel van vrouwen duidelijk het hoogst $(75 \%)$. Daarna volgen de FdR met $48 \%$ en de FdG met $45 \%$. Bij de FdEW is het aandeel van vrouwen het laagst (21\%).

Gebleken is dat de onderzochte populatie, wat de verdeling naar geslacht betreft, bijna exact overeenkomt met de totale populatie. De totale populatie bestaat voor $55 \%$ uit vrouwen, terwijl bij de respondenten het aandeel van vrouwen -zoals reeds vermeld- $56 \%$ bedraagt.

\section{Leeftijd}

Ook de leeftijd bij het afstuderen kan een relevant achtergrondkenmerk vormen. Naarmate academici jonger afstuderen kunnen zij makkelijker in het arbeidsproces worden opgenomen en kunnen de baten van de opleiding en de eventuele 'on the job' training over een langere periode worden genoten. Men zou derhalve een gunstiger arbeidsmarktpositie verwachten voor academici die op jongere leeftijd afstuderen.

Gemiddeld zijn de studenten 26,2 jaar oud wanneer zij de RL verlaten. Deze leeftijd is berekend als het verschil tussen het kalenderjaar van afstuderen en het geboortejaar. De leeftijd bij afstuderen is afhankelijk van het gevolgde vooropleidingstraject en de studieduur aan de RL. Laatstgenoemde factor vormt -zoals hierboven aangegeven- de resultante van de nominale studieduur van het aan de RL gevolgde curriculum en het studietempo. De nominale studieduur varieert, afhankelijk van de studierichting in combinatie met de vooropleiding. Voor bijvoorbeeld economiestudenten met een VWO vooropleiding bedraagt deze vier jaar en voor van de HEAO afkomstige economiestudenten drie jaar.

De gemiddelde leeftijd bij afstuderen is het hoogst bij basisartsen (26,7 jaar) en juristen (26,3 jaar) en het laagst bij economen (24,9 jaar). Gezondheidswetenschappers nemen met gemiddeld 25,8 jaar een tussenpositie in. Ondanks hun nominale studieduur van zes jaar zijn basisartsen

17. Lodder, B.J.H., e.a. (1991), Arbeidsmarktindicatoren ten behoeve van het emancipatiebeleid aan de Rijksuniversiteit Limburg, ROA-R-1991/7, Maastricht 
op het moment van afstuderen gemiddeld maar 0,7 jaar ouder dan andere afgestudeerden van de RL. Hierbij kan een rol spelen dat de afgestudeerden van andere faculteiten, zoals hieronder zal blijken, vaker een HBO of WO opleiding hebben afgesloten vór zij gaan studeren aan de RL.

\section{Vooropleiding}

Het beschikken over een einddiploma van een opleiding op HBO- of universitair niveau vórdat men aan de RL gaat studeren, evenals het afstuderen in meer dan éen studie- of afstudeerrichting, biedt een extra kwalificatie waarop men kan terugvallen bij de oriëntatie op de arbeidsmarkt. Van de onderzochte oud-studenten blijkt $13 \%$ te beschikken over een HBOdiploma en $1 \%$ over een doctoraal-diploma, voordat zij aan de $\mathrm{RL}$ gingen studeren. Degenen die uit het HBO afkomstig zijn kozen doorgaans een studierichting aan de RL die qua richting aansluit bij hun HBO-diploma. Zo kozen degenen met een diploma in het HBO-gezondheidszorg doorgaans voor geneeskunde of gezondheidswetenschappen en HEAO'ers voor economie. Juristen met een HBO-diploma zijn relatief vaak afkomstig van sociale academies.

Voor de meeste studenten ( $81 \%$ van de mannen en $86 \%$ van de vrouwen) vormt echter het VWO de hoogste voltooide opleiding vóor de studie aan de RL. Met name basisartsen zijn vrijwel uitsluitend afkomstig uit het VWO. Hiervan geeft tabel 3 in bijlage 1 een beeld.

Betaalde werk- en bestuurlijke ervaring voór of tijdens de studie aan de RL

Het beschikken over betaalde werkervaring of bestuurlijke ervaring vór afstuderen kan een positieve invloed hebben op het vinden van betaald werk na afstuderen.

Aan de respondenten is de vraag voorgelegd of men vóor of tijdens de studie aan de RL betaald werk (vakantie-/weekendwerk niet inbegrepen) heeft verricht. De resultaten worden vermeld in tabel 4 in bijlage 1 . Hierin komt naar voren dat iets meer dan de helft van de oud-studenten vóór het afstuderen aan de RL betaalde werkervaring heeft opgedaan, meestal als studentassistent. Hierbij doet zich het 'eerste lichtingen' effect gelden. Vooral economen en gezondheidswetenschappers hebben vaak (meestal als student-assistent) betaalde arbeid verricht. Juristen beschikken relatief vaak over betaalde werkervaring buiten hun vakgebied voordat zij afstuderen.

Ruim éénderde (36\%) van de oud-studenten heeft vór of tijdens de studie enigerlei vorm van bestuurlijke ervaring opgedaan. Ten aanzien van dit kenmerk doen zich geen grote verschillen tussen de faculteiten voor: bij basisartsen bedraagt het percentage 37 , bij gezondheids- 
wetenschappers 33, bij juristen 38 en bij economen 42 .

\subsection{Samenvatting}

Gezien de nog recente start van het onderwijs in gezondheidswetenschappen, Nederlands recht en economie aan de $R L$, gaat het bij de tot nu onderzochte jaargangen om de eerste lichtingen afgestudeerden van deze faculteiten. Dit heeft consequenties voor het thans verrichte onderzoek onder afgestudeerden van met name twee faculteiten. Met betrekking tot de FdEW, waarbinnen het onderwijs pas in 1984 van start is gegaan, heeft dit tot gevolg dat er nog maar weinig economen konden worden geënquêteerd. Voor de FdGW zijn de aantallen afgestudeerden in de andere varianten dan $\mathrm{BB}, \mathrm{GVO}$ en $\mathrm{VW}$ nog te gering om uitsplitsingen naar deze varianten te maken.

De jaren waarin de onderzochte jaargangen afgestudeerden de arbeidsmarkt hebben betreden, namelijk 1986 tot en met 1989, worden getypeerd door een ongunstige situatie op de arbeidsmarkt voor intredende academici. Aan de aanbodkant deed zich in deze jaren namelijk een versnelde groei van het aantal universitair geschoolde instromers op de arbeidsmarkt voor en aan de vraagzijde manifesteerden zich omvangrijke bezuinigingen in de kwartaire sector, de traditionele bron van werkgelegenheid voor academici.

De onderzochte afgestudeerden die in deze jaren de arbeidsmarkt hebben betreden, bestaan voor meer dan de helft uit vrouwen, waarbij de FdGW het hoogste percentage vrouwelijke afgestudeerden heeft en de FdEW het laagste. Ondanks hun nominale studieduur van zes jaar zijn basisartsen bij afstuderen gemiddeld maar 0,7 jaar ouder dan de andere afgestudeerden. Hierbij dient te worden opgemerkt dat de afgestudeerden van de andere faculteiten vaker reeds een HBO of WO opleiding hadden voltooid voordat zij aan de RL gingen studeren. lets meer dan de helft van de afstudeerders beschikt over extra kwalificaties in de vorm van betaalde werkervaring, meestal als studentassistent. Dit is met name bij economen het geval. Ruim éénderde van de afstudeerders beschikt over extra kwalificaties in de vorm van bestuurlijke ervaring. 


\section{INTREDE OP DE ARBEIDSMARKT}

\subsection{Het begrip arbeidsmarktpositie}

Een goede arbeidsmarktpositie van een intreder op de arbeidsmarkt wordt onder meer gekenmerkt door een korte duur van de intredewerkloosheid, het vervullen van een betaalde functie waarvoor de gevolgde studie beoogt op te leiden en waarin men wil blijven werken, een vaste aanstelling en een goede salariering. Een slechte arbeidsmarktpositie daarentegen kenmerkt zich door werkloosheid of door tijdelijk, slecht betaald werk dat ligt onder het niveau waarvoor men is opgeleid en door het zoeken naar ander werk. Aan deze typering van een goede en slechte arbeidsmarktpositie worden in dit rapport een zestal dimensies van het begrip arbeidsmarktpositie ontleend: intredewerkloosheid, arbeidssituatie, baanstabiliteit, potentiële baanmobiliteit, inkomen en vereiste opleiding (aansluiting van de baan op de gevolgde studie). Deze dimensies hoeven voor een individu overigens niet volledig met elkaar samen te hangen. Voor een individu behoeven dus niet alle dimensies één en dezelfde richting uit te wijzen, maar kunnen sommige dimensies op een slechte en andere op een goede arbeidsmarktpositie duiden. Er zal hoogstens sprake zijn van een correlatief verband tussen de onderscheiden dimensies.

De genoemde zes dimensies zullen in dit rapport worden gebruikt om het begrip arbeidsmarktpositie te operationaliseren. Eerst zullen deze dimensies echter nog wat nader worden omschreven.

\section{Intredewerkloosheid}

De duur van de intredewerkloosheid, dit wil zeggen de duur van de werkloosheid tussen afstuderen en de eerste baan, geeft een indicatie voor de mate waarin de intrede op de arbeidsmarkt succesvol verloopt.

\section{Arbeidssituatie}

De dimensie arbeidssituatie verwijst naar de situatie die volgens de respondenten het beste past bij hun dagelijkse bezigheden. De arbeidssituatie wordt geoperationaliseerd als het al dan niet hebben van een betaalde baan. Ook degenen die binnen hun functie betaald werken combineren met het volgen van een opleiding, bijvoorbeeld Assistenten In Opleiding en Assistent Geneeskundigen In Opleiding, hebben een betaalde baan. 


\section{Baanstabiliteit}

De dimensie baanstabiliteit verwijst naar twee kenmerken van de aanstelling. Het eerste kenmerk van baanstabiliteit is het aantal maanden waarop de formele aanstelling in loondienst betrekking heeft (de baanzekerheid). De baanzekerheid wordt geoperationaliseerd door het onderscheiden van twee mogelijkheden: een tijdelijk dienstverband (aanstelling voor bepaalde tijd) of een vast dienstverband (aanstelling voor onbepaalde tijd). Degenen met een aanstelling voor meer dan vijf jaar worden hierbij geacht een vast dienstverband te hebben. Het tweede kenmerk van baanstabiliteit is de lengte van de werkweek, waarbij een hoofdonderscheid tussen full-time functies en part-time functies zal worden gemaakt.

\section{Potentiële baanmobiliteit}

Het al dan niet zoeken naar een andere baan kan worden gezien als een indicatie voor de mate van tevredenheid met de baan die men heeft. Men zal doorgaans niet op zoek gaan naar ander werk als men tevreden is met de baan die men heeft. Omgekeerd zal men wel ander werk zoeken als de baan die men heeft niet bevalt.

\section{Inkomen en vereiste opleiding}

Het bruto inkomen per maand bij een volledige werkweek, het voor de uitoefening van de functie vereiste opleidingsniveau, evenals het al dan niet leiding geven, bieden indicaties voor het niveau van het werk. De vereiste opleiding naar niveau én richting is tevens indicatief voor de aansluiting van de gevolgde studie op de uitgeoefende functie.

Bij de beschrijving van deze dimensies van het begrip arbeidsmarktpositie zal steeds onderscheid worden gemaakt naar faculteit (studierichting) en naar geslacht. Bovendien zal bij de FdGW onderscheid worden gemaakt naar de drie oudste afstudeerrichtingen waarbinnen ruim driekwart van de gezondheidswetenschappers is afgestudeerd: beleid en beheer van gezondheidszorgvoorzieningen (BB), gezondheidsvoorlichting en -opvoeding (GVO) en verplegingswetenschap (VW). De dimensies 'intredewerkloosheid' en 'arbeidssituatie' hebben betrekking op de hele populatie. De andere dimensies zijn uiteraard alleen van toepassing op degenen die erin zijn geslaagd om een betaalde baan te verwerven.

Dit hoofdstuk betreft de fase direct na het afstuderen, als men de arbeidsmarkt betreedt. De intrede op de arbeidsmarkt wordt achtereenvolgens behandeld aan de hand van een drietal items. Eerst volgt een beschrijving van de veranderingen in de arbeidssituatie die zich in de loop 
van het eerste jaar na afstuderen hebben voorgedaan. Vervolgens wordt de verwachte duur van de intredewerkloosheid verklaard. Tot slot wordt bekeken op welke wijze men de intredebaan heeft gekregen.

\subsection{Verschuivingen in arbeidssituatie tijdens het eerste jaar na afstuderen}

In deze paragraaf wordt ingegaan op de verschuivingen in arbeidssituatie die zich in de loop van het eerste jaar na afstuderen hebben voorgedaan. Het verloop van de intrede op de arbeidsmarkt is in tabel 5 zichtbaar gemaakt door het aandeel van alle ondervraagden van alle onderzochte jaargangen weer te geven dat betaald werk heeft, respectievelijk direct na afstuderen, drie maanden na afstuderen, een half jaar na afstuderen en 12 maanden na afstuderen. Hierbij is het aandeel van betaald werkenden uitgesplitst naar achtereenvolgens faculteit en geslacht.

Tabel 5. Het aandeel van betaald werkenden tijdens het eerste jaar na afstuderen, naar faculteit en naar geslacht (in \%)

\begin{tabular}{lcccccccr}
\hline & \multicolumn{9}{c}{ Afgestudeerden van de } & \multicolumn{3}{c}{ Geslacht } \\
Periode na afstuderen & FdG & FdGW & FdR & FdEW & Man & Vrouw & Totaal \\
\hline $\begin{array}{l}\text { Eerste maand na afstuderen/ } \\
\text { kwartaal van afstuderen }\end{array}$ & 36 & 38 & 33 & 76 & 40 & 36 & 38 \\
$\begin{array}{l}\text { Derde maand na afstuderen/ } \\
\text { eerste kwartaal na afstuderen }\end{array}$ & 55 & 49 & 39 & 83 & 50 & 48 & 49 \\
$\begin{array}{l}\text { Zesde maand na afstuderen/ } \\
\text { tweede kwartaal na afstuderen }\end{array}$ & 70 & 58 & 48 & 88 & 57 & 62 & 60 \\
$\begin{array}{l}\text { Twaalfde maand na afstuderen/ } \\
\text { vierde kwartaal na afstuderen }\end{array}$ & 80 & 70 & 60 & 95 & 69 & 72 & 71 \\
\hline
\end{tabular}

De intrede op de arbeidsmarkt blijkt eerst vrij moeizaam te verlopen, behalve bij economen. Drie maanden na afstuderen verricht nog geen $50 \%$ van de afgestudeerden betaald werk. Het aandeel van betaald werkenden neemt echter in snel tempo toe van $60 \%$ een half jaar na afstuderen, tot $71 \%$ één jaar na verlaten van de RL. De toename van het aandeel van betaald werkenden gedurende het eerste jaar na afstuderen doet zich weliswaar bij alle faculteiten voor, maar niet in gelijke mate. De waargenomen verschillen zijn significant. Direct na afstuderen hebben economen een riante voorsprong op de arbeidsmarkt. Daarom ziet men daarna slechts een kleine toename optreden van het aandeel dat betaald werk krijgt. Bij gezondheidswetenschappers en vooral juristen geeft de arbeidssituatie tijdens het eerste jaar na afstuderen een zorgwekkend verloop te zien. De mate waarin het aandeel van betaald werkende 
gezondheidswetenschappers en juristen toeneemt is onvoldoende groot om de relatief grote achterstand op de arbeidsmarkt kort na afstuderen te compenseren. Als resultante van het voorgaande is het aandeel van betaald werkenden onder gezondheidswetenschappers en juristen één jaar na afstuderen duidelijk lager dan onder basisartsen en economen.

De aandelen naar geslacht verschillen op de onderscheiden meetmomenten niet significant van elkaar.

Zoals in paragraaf 4.1 is opgemerkt, kan de algemene situatie op de arbeidsmarkt waarmee intredende academici worden geconfronteerd, van jaar tot jaar verschillend zijn. Nagegaan is of het verloop van de arbeidsmarktintrede in het eerste jaar na afstuderen verschilt naar gelang het jaar waarin men is afgestudeerd. Hiervan geeft tabel 5 in bijlage 1 een beeld. Uit deze tabel komt naar voren dat de intrede op de arbeidsmarkt van de achtereenvolgende cohorten 1986, 1987 en 1988 steeds moeizamer verloopt: het aandeel van de afgestudeerden dat er in slaagt om in het eerste jaar na afstuderen betaald werk te vinden neemt bij deze cohorten gestaag af. Bedroeg het aandeel van betaald werkenden over de vier meetmomenten na afstuderen bij cohort ' 86 nog gemiddeld $64 \%$, bij cohort ' 87 was het gemiddelde gedaald naar $57 \%$ om bij cohort ' 88 op een dieptepunt van $50 \%$ uit te komen. Het lijkt erop dat de situatie op de arbeidsmarkt, waarmee pas afgestudeerde academici werden geconfronteerd, in deze periode is verslechterd. Hierin lijkt na 1988 enige verbetering op te treden. De daling van het gemiddelde percentage betaald werkenden, berekend over de vier meetmomenten na afstuderen, gaat bij cohort ' 89 over in een lichte stijging (tot $52 \%$ ).

\subsection{Intredewerkloosheid}

De duur van de intredewerkloosheid geeft een indicatie voor de mate waarin de intrede op de arbeidsmarkt succesvol verloopt. Bij het onderzoeken van de tijdsduur die pas afgestudeerden werkloos zijn voordat zij hun eerste betaalde baan vinden, doet zich echter het probleem voor dat niet iedereen er op het moment van bevraging in is geslaagd om een baan te vinden. Het nog niet voltooid zijn van de werkloosheidsduur voor een deel voor de populatie, maakt het moeilijk om de gemiddelde werkloosheidsduur te bepalen. Om dit probleem te ondervangen moet de niet voltooide werkloosheidsduur worden geschat. Hiervoor is een aantal modellen ontwikkeld, die in bijlage 2 kort worden beschreven. In dit onderzoek is gekozen voor het proportional hazards model. In dat model heeft de kans om aan werkloosheid te ontsnappen, gegeven een bepaalde periode dat men al werkloos is, een bepaalde waarde die tussen de onderscheiden individuen kan verschillen afhankelijk van hun achtergrondkenmerken. Het model is met behulp van een semi-parametrische methode geschat. Hierbij zijn 25 cases uit het 
gegevensbestand van 1100 afgestudeerden weggelaten, waarvoor de werkloosheidsduur niet kon worden bepaald. Ook alle werkloosheidsduren die eindigden met militaire dienstplicht zijn weggelaten, omdat in deze gevallen de verschillen in werkloosheidsduur niet te herleiden zijn tot verschillen in persoonlijke kenmerken. Uiteindelijk bleven er 1018 personen over voor analyse.

De schattingsresultaten zijn weergegeven in bijlage 2. De vermelde resultaten geven de invloed weer van de individuele kenmerken van de afgestudeerden op de kans om aan een langere duur van de werkloosheid te ontsnappen (de 'hazard'). Een positieve coëfficiënt betekent dat het desbetreffende kenmerk leidt tot een grotere kans, gegeven dat men al een bepaalde tijd werkloos is, om aan die situatie te ontsnappen. Dat kenmerk heeft dus een gunstig effect op de werkloosheidsduur. Hierbij dient er op te worden gewezen dat uitstroom uit een situatie van intredewerkloosheid naar full-time onderwijs in een aantal gevallen kan duiden op verkapte werkloosheid. Wanneer de perspectieven op de arbeidsmarkt voor een bepaalde studierichting erg slecht zijn, kan men immers besluiten om full-time verder onderwijs te gaan volgen in afwachting van een eventuele baan. Aangezien dit waarschijnlijk niet in alle gevallen speelt waarin full-time onderwijs wordt gevolgd na te zijn afgestudeerd, kan er in de schatting niet voor worden gecorrigeerd. Ook is niet a priori duidelijk in welke richting dit een vertekening zal geven van de schattingsresultaten.

Uit de resultaten blijkt dat leeftijd een significant negatieve invloed heeft op de hazard (enigszins gecorrigeerd door leeftijd in het kwadraat), dus leidt tot een langere duur van de intredewerkloosheid. De invloed van geslacht is niet significant.

Afgestudeerden die over extra kwalificaties beschikken, hetzij in de vorm van studiediploma's, hetzij in de vorm van bestuurlijke ervaring, blijken na afstuderen minder lang werkloos te zijn. Alle vormen van betaalde werkervaring, opgedaan voor of tijdens de studie aan de RL hebben een weliswaar niet significante maar wel positieve invloed op de hazard. Ook de invloed van bestuurlijke ervaring is positief en is bovendien significant. De invloed van een voltooide vooropleiding op HBO of WO niveau is eveneens significant positief. Dit betekent dat afgestudeerden van de $\mathrm{RL}$ met een dergelijke vooropleiding sneller een baan vinden dan degenen met alleen het VWO diploma en het universitaire einddiploma.

De coëfficiënten van de variabelen die betrekking hebben op de studierichting of, in het geval van gezondheidswetenschappen, de afstudeerrichting, geven de invloed op de hazard aan, vergeleken met de als referentiecategorie gekozen opleiding tot basisarts. Daarmee vergeleken blijken de afstudeerrichtingen in de gezondheidswetenschappen GVO, BB en Overig GW significant lager te scoren. Afgestudeerden van deze afstudeerrichtingen doen er dus langer 
over om een baan te vinden. Ook de andere gespecificeerde afstudeerrichting binnen gezondsheidswetenschappen, VW, blijkt lager te scoren dan de referentiecategorie, maar dit effect is echter niet significant. De studierichting economie scoort hoger en de studierichting Nederlands recht lager dan de referentiestudie.

De situatie op de arbeidsmarkt waarmee men na het afstuderen wordt geconfronteerd kan van jaar tot jaar verschillen door ontwikkelingen aan zowel de vraag- als de aanbodzijde. Daarom is ook het jaar waarin men is afgestudeerd als verklarende variabele in de schatting opgenomen. Uit de schattingen blijkt evenwel van de jaren 1987, 1988 en 1989 alleen het laatste jaar (1989) weliswaar net niet significant maar wel beter te scoren dan het referentiejaar 1986. Dit zou er op kunnen duiden dat de arbeidsmarkt voor intredende academici zich na enkele moeilijke jaren aan het herstellen is. Het is mogelijk dat het effect van de gelijktijdige instroom op de arbeidsmarkt van de laatste generaties 'oude-stijl' afgestudeerden en van de eerste generaties 'eerste-fase' afgestudeerden is uitgewerkt.

\subsection{Verwerving van de eerste baan}

In paragraaf 5.2. is onderzocht hoe lang het duurt voordat academici met hun eerste betaalde baan na afstuderen beginnen. In deze paragraaf komt de vraag aan bod op welke wijze zij deze baan hebben gevonden ${ }^{18}$. Het antwoord op deze vraag is niet alleen indicatief voor de gehanteerde zoekmethoden, maar geeft vooral een beeld van het belang van persoonlijke netwerken bij het verkrijgen van de eerste baan. Hiervan geeft tabel 6 een beeld.

Uit deze tabel komt naar voren dat de meeste (driekwart) academici hun eerste betaalde baan via formele kanalen verwerven. Dit gebeurt meestal door op een vacature-advertentie te solliciteren of door ongevraagd te solliciteren (open sollicitaties). Vacature-advertenties blijken vooral voor gezondheidswetenschappers en juristen van belang te zijn en open sollicitaties vooral voor basisartsen en economen.

Persoonlijke netwerken (familie, vrienden, medewerkers van de RL) spelen duidelijk een ondergeschikte rol. Dit geldt voor juristen in nog sterkere mate dan voor basisartsen, gezondheidswetenschappers en economen. De wijze van functieverwerving naar geslacht is hier niet weergegeven, maar is wel geanalyseerd. Mannen en vrouwen blijken evenwel niet

18. Deze vraag is alleen gesteld aan degenen die vóór juli 1988 zijn afgestudeerd. Aan degenen die later zijn afgestudeerd is alleen gevraagd op welke wijze men de huidige baan heeft verkregen. Met betrekking tot de huidige baan van de recenter afgestudeerden kon echter worden nagegaan of dit al dan niet de eerste baan na afstuderen betreft. 
significant te verschillen ten aanzien van de wijze waarop zij hun eerste baan hebben gevonden.

Tabel 6. Wijze waarop de eerste functie na afstuderen is verkregen, naar faculteit (in \%); én antwoord mogelijk

\begin{tabular}{|c|c|c|c|c|c|}
\hline \multirow[b]{2}{*}{ Functieverwerving } & \multirow[b]{2}{*}{ FdG } & \multicolumn{2}{|c|}{ Afgestudeerden van de } & \multirow[b]{2}{*}{ FdEW } & \multirow[b]{2}{*}{ Totaal } \\
\hline & & FdGW & $\mathrm{FdR}$ & & \\
\hline Familie & 14 & 7 & 6 & 3 & 9 \\
\hline Medewerkers RL & 2 & 12 & 3 & 9 & 6 \\
\hline Studentassistentschap & 3 & 1 & 2 & 3 & 2 \\
\hline Stage-contacten & 7 & 10 & 7 & 9 & 9 \\
\hline Reageren op advertentie & 15 & 47 & 38 & 21 & 33 \\
\hline Gewestelijk Arbeidsbureau & 2 & 1 & 4 & -- & 2 \\
\hline Uitzendbureau & 4 & 1 & 6 & -- & 3 \\
\hline Wervingsbureau & 1 & -- & 1 & -- & 1 \\
\hline Vrijwilligerswerk & 2 & 1 & -- & -- & 1 \\
\hline Open sollicitatie & 31 & 5 & 13 & 50 & 17 \\
\hline Benaderd door werkgever & 14 & 12 & 13 & 6 & 13 \\
\hline Zelf bedrijf/praktijk opgezet & 2 & 1 & 3 & -- & 2 \\
\hline Andere wijze & 3 & 2 & 3 & -- & 2 \\
\hline Totaal $n(=100 \%)$ & 227 & 289 & 231 & 34 & 781 \\
\hline
\end{tabular}

\subsection{Samenvatting}

In paragraaf 4.1 is er reeds op gewezen dat de onderzochte jaargangen afgestudeerden zijn geconfronteerd met een voor intredende academici ongunstige situatie op de arbeidsmarkt. De intrede op de arbeidsmarkt blijkt dan ook aanvankelijk vrij moeizaam te verlopen. Drie maanden na afstuderen verricht nog niet de helft betaald werk. Na een half jaar is het percentage opgelopen tot 60 . Daarna stijgt het aandeel van betaald werkenden tot $71 \%$, éen jaar na verlaten van de RL.

Bij gezondheidswetenschappers en juristen is de mate waarin het aandeel van betaald werkenden gedurende het eerste jaar van de arbeidsmarktintrede toeneemt onvoldoende groot om hun relatief grote achterstand op de arbeidsmarkt kort na afstuderen te compenseren. Uit de schatting van de individuele duur van de intredewerkloosheid, waarbij naast de studierichting is rekening gehouden met de invloed van een aantal andere kenmerken van de respondenten, komt dan ook naar voren dat men na afstuderen significant langer werkloos is wanneer men rechten of gezondheidswetenschappen (met uitzondering van VW) heeft gestudeerd.

Uit deze schatting bleek dat de duur van de intredewerkloosheid eveneens langer is wanneer men op oudere leeftijd is afgestudeerd. Afgestudeerden met extra kwalificaties in de vorm van 
een voltooide vooropleiding op HBO of WO niveau of in de vorm van bestuurlijke ervaring zijn daarentegen na afstuderen minder lang werkloos.

Uit de duuranalyse volgt dus dat basisartsen en economen significant minder tijd nodig hebben om de eerste baan te vinden. Hoewel de significantie hiervan niet kan worden nagegaan, is het opmerkelijk dat zij deze baan vaker verwerven via open sollicitaties dan gezondheidswetenschappers en juristen. 


\section{MOBILITEIT}

\subsection{Inleiding}

Bij mobiliteit, hier begrepen als verandering van functie, kan onderscheid worden gemaakt tussen:

- externe mobiliteit ('job mobility'), dit wil zeggen verandering van werkgever of werkorganisatie;

- interne mobiliteit ('function mobility'), dit wil zeggen verandering van functie bij dezelfde werkgever, bijvoorbeeld promotie, overplaatsing of substantiële verandering van de inhoud van de werkzaamheden.

Externe mobiliteit kan met verandering van bedrijfssector ('industrial mobility') gepaard gaan. Mobiliteit, zowel extern als intern, kan verandering van beroep impliceren ('occupational mobility'), evenals verandering van de mate van baanzekerheid (formele duur van de arbeidsovereenkomst en lengte van de werkweek). Mobiliteit kan ook leiden tot verhoging van het functie-niveau (inkomen en mate van leidinggeven) en gevolgen hebben voor de mate waarin de functie aansluit bij de gevolgde studie. 'Job change may offer the individual a higher income, better working-conditions or a more stable contract ${ }^{19}$.

In paragraaf 6.2. wordt de omvang van de baan- en functiemobiliteit geschetst. In de daaropvolgende paragrafen wordt ingegaan op bovengenoemde veranderingen die als gevolg van mobiliteit kunnen optreden. Met nadruk wordt erop gewezen dat dergelijke veranderingen tot nu toe alleen zijn gemeten bij degenen die in de periode januari 1986 - juni 1988 zijn afgestudeerd ( $n=545$, ofwel $50 \%$ van alle respondenten). Bij het opstarten van de arbeidsmarktscanner is deze populatie namelijk eenmalig benaderd met een aangepaste basisvragenlijst, waarbij de loopbaan retrospectief in kaart werd gebracht. Bij de beschrijving van de veranderingen die optreden door mobiliteit, moet worden bedacht dat $5 \%$ van deze subpopulatie van 545 personen nooit betaalde arbeid heeft verricht, terwij $31 \%$ uitsluitend in dezelfde functie bij één werkgever heeft gewerkt. Dit betekent dat $65 \%$ van deze sub-populatie extern en/of intern mobiel is geweest. Dit komt er op neer dat bij slechts $32 \%$ van de totale onderzochte populatie van 1100 personen veranderingen door mobiliteit in kaart kunnen worden gebracht.

19. Van Ours (1990), blz. 33. 


\subsection{Omvang van de mobiliteit}

In tabel 7 zijn de enquêteresultaten weergegeven met betrekking tot de mobiliteit van de afgestudeerden. Van alle onderzochte oud-studenten is $37 \%$ na afstuderen nooit mobiel geweest, omdat men slechts bij éen werkgever in één functie heeft gewerkt. Bij deze nog geringe mobiliteit dient te worden bedacht dat het om academici gaat die nog niet zo lang geleden ( 1 tot 4 jaar) zijn afgestudeerd.

Ruim ééntiende van de onderzochte oud-studenten heeft na afstuderen nog nooit een betaalde baan gehad. Dit impliceert niet noodzakelijkerwijs dat zij ook de hele tijd werkloos zijn geweest. Zij kunnen in die periode bijvoorbeeld full-time onderwijs hebben gevolgd. Slechts $2 \%$ van de totale populatie is na afstuderen steeds werkloos geweest. Vooral onder juristen komt het vaak voor dat men nooit een betaalde functie heeft uitgeoefend. Ten aanzien van het al dan niet verwerven van een baan hebben zich geen verschillen tussen mannen en vrouwen gemanifesteerd.

Zoals eerder is opgemerkt heeft bijna $40 \%$ slechts in én functie gewerkt. Dit is met name bij economen vaak het geval. De geringe mobiliteit onder afgestudeerden van deze richting kan wellicht worden toegeschreven aan het feit dat de onderzochte economen pas én tot twee jaar geleden zijn afgestudeerd en een aanzienlijk aantal een door de werkgever betaalde accountantsopleiding volgt (zie tabel $14 \mathrm{~A}$ in bijlage 1 ).

Tabel 7. Omvang van de mobiliteit, naar faculteit en naar geslacht (in \%)

\begin{tabular}{|c|c|c|c|c|c|c|c|}
\hline \multirow{2}{*}{ Mobiliteit } & \multicolumn{4}{|c|}{ Afgestudeerden van de } & \multirow[b]{2}{*}{ Totaal } & \multirow[b]{2}{*}{ Man } & \multirow[b]{2}{*}{ Vrouw } \\
\hline & FdG & FdGW & FdR & FdEW & & & \\
\hline Nooit betaalde baan verworven & 4 & 11 & 22 & 7 & 12 & 13 & 12 \\
\hline Geen mobiliteit & 29 & 41 & 35 & 76 & 37 & 38 & 36 \\
\hline Alleen interne mobiliteit & 6 & 14 & 11 & 5 & 10 & 9 & 11 \\
\hline Alleen externe mobiliteit & 41 & 26 & 20 & 7 & 28 & 26 & 29 \\
\hline Zowel externe als interne mobiliteit & 15 & 6 & 9 & 0 & 10 & 10 & 9 \\
\hline Mobiliteit onbekend & 5 & 2 & 3 & 5 & 3 & 5 & 2 \\
\hline Totaal $n(=100 \%)$ & 330 & 385 & 343 & 42 & 1100 & 488 & 612 \\
\hline
\end{tabular}

Uit de gegevens over de helft van de oud-studenten die na afstuderen wel mobiel zijn geweest, dit wil zeggen dat zij meer functies dan alleen de intredefunctie hebben uitgeoefend, blijkt dat in het beginstadium van de beroepsloopbaan mobiliteit vaker bestaat uit een verandering van 
werkgever (baanmobiliteit) dan uit een verandering van functie bij dezelfde werkgever (functiemobiliteit). Vooral basisartsen zijn vaak van baan (werkgever) veranderd. Hierbij kan een rol hebben gespeeld dat een aantal van hen eerst tijdelijk een baan heeft geaccepteerd, in afwachting van een opleidingsplaats voor medisch specialist (waaronder die voor huisarts en sociaal-geneeskundige). Hierop wordt in paragraaf 8.4. terug gekomen.

\subsection{Bedrijfssector- en beroepsmobiliteit}

In deze paragraaf wordt eerst nagegaan of externe mobiliteit, dus verandering van werkgever, is samengegaan met verandering van bedrijfssector. Vervolgens komt aan bod of mobiliteit, zowel extern als intern, gepaard is gegaan met verandering van beroep.

\section{Sectormobiliteit}

Door de bedrijfssector van de eerste werkorganisatie na afstuderen te vergelijken met die van de huidige werkorganisatie, kan worden nagegaan of er bij baanmobiliteit sprake is van intrasectorale mobiliteit (verandering van baan binnen dezelfde sector) danwel inter-sectorale mobiliteit (verandering van bedrijfssector). De omvang van beide vormen van mobiliteit geeft een indicatie voor de mate waarin de arbeidsmarkt sectoraal is gesegmenteerd en daarmee voor de uitwijkmogelijkheden van afgestudeerden naar andere bedrijfssectoren. Hierop wordt in paragraaf 7.3.2. nader ingegaan.

Onder bedrijfssector wordt verstaan: een op basis van het soort produkt of dienst min of meer homogene groep van werkorganisaties. De benamingen van de bedrijfssectoren met de bijbehorende coderingen zijn afgeleid uit de Standaard BedrijfsIndeling (SBI) die door het CBS wordt gehanteerd. De bedrijfssectoren zijn in dit onderzoek gecodeerd op vier-cijferig niveau, dit wil zeggen het niveau van bedrijfssubgroepen.

De omvang van de externe baanmobiliteit onder degenen die in de periode januari 1986 - juni 1988 zijn afgestudeerd bedraagt $51 \%$, dit betekent dat de helft al eens van werkgever is veranderd. Het genoemde percentage is als volgt verdeeld over intra- en intersectorale mobiliteit. De omvang van de intrasectorale mobiliteit bedraagt $9 \%$ van degenen die in de periode januari 1986 - juni 1988 zijn afgestudeerd en de intersectorale mobiliteit bedraagt $42 \%$ van deze groep afgestudeerden. Per saldo is dus in $82 \%$ van de gevallen dat van werkgever werd veranderd dit gepaard gegaan met verandering van bedrijfssubgroep. Gemeten op een hoger aggregatieniveau, namelijk op het twee-cijferig niveau van bedrijfsklassen, heeft baanmobiliteit in nog altijd $52 \%$ van de mobiliteitsgevallen geleid tot sectormobiliteit. De arbeidsmarkt van recent afgestudeerde 
academici van de RL is bijgevolg niet sterk sectoraal gesegmenteerd. Men heeft dus veel uitwijkmogelijkheden naar andere bedrijfssectoren.

\section{Beroepsmobiliteit}

Door het beroep dat in de eerste functie na afstuderen wordt uitgeoefend te vergelijken met het in de huidige functie uitgeoefende beroep, kan worden nagegaan of mobiliteit is samengegaan met verandering van beroep. De omvang van de beroepsmobiliteit geeft een indicatie voor de mate waarin de arbeidsmarkt naar beroep is gesegmenteerd en daarmee voor de uitwijkmogelijkheden naar andere beroepen. Evenals de bedrijfssector is het beroep gecodeerd op vier-cijferig niveau. De bij de beroepsgroepen behorende coderingen zijn afgeleid uit de beroepenclassificatie die door het CBS wordt gehanteerd.

Eerder is opgemerkt dat $31 \%$ van de nader beschouwde subpopulatie van reeds langer afgestudeerden slechts in één functie bij éen werkgever heeft gewerkt. Bijna tweederde (65\%) is al eens van baan (werkgever) en/of functie (binnen dezelfde baan) veranderd. Van de totale subpopulatie is $39 \%$ al eens van beroep veranderd (beroepsmobiliteit). Per saldo is dus in $62 \%$ van de gevallen dat mobiliteit optrad tevens het beroep veranderd. In een aantal gevallen heeft dit geleid tot een verhoging van het functieniveau. Hierop wordt in de volgende paragraaf ingegaan.

Uit de gegevens over de sector- en beroepsmobiliteit blijkt dat de arbeidsmarkt van recent afgestudeerde academici weliswaar iets sterker naar beroep is gesegmenteerd dan naar bedrijfssubgroep, maar dat de uitwijkmogelijkheden naar andere beroepen nog altijd zeer aanzienlijk zijn. Hierop wordt, gedifferentieerd naar opleidingsrichting, in paragraaf 7.3.2. nader ingegaan.

\subsection{Verandering in baanzekerheid en werktijdfactor}

Met name het vaste of tijdelijke karakter van de arbeidsovereenkomst met een werkgever (de baanzekerheid) is indicatief voor de stabiliteit van de baan. Een stabiele baan kan worden getypeerd door een aanstelling voor onbepaalde tijd. Een instabiele baan daarentegen kan worden omschreven als een tijdelijke aanstelling.

Academici beginnen hun loopbaan doorgaans in tijdelijke banen. Slechts weinigen slagen er in om meteen een vaste aanstelling te verwerven. $\mathrm{Na}$ verloop van tijd echter slagen meer academici hierin. Uit de enquêteresultaten blijkt dat het aandeel van vaste aanstellingen 
toeneemt van $13 \%$ in de intredebaan tot $21 \%$ in de huidige baan.

Tabel 8. Verschuivingen in baanzekerheid tijdens de loopbaan (in \%)

\begin{tabular}{llr}
\hline & Dienstverband & \\
Intredebaan & Huidige baan & \\
\hline Niet-mobielen & & 8 \\
Vast & Vast & 23 \\
Tijdelijk & Tijdelijk & 3 \\
Mobielen & Vast & 2 \\
Vast & Tijdelijk & 54 \\
Vast & Tijdelijk & 10 \\
Tijdelijk & Vast & 467 \\
Tijdelijk & & \\
Totaal n (100\%) & & \\
\hline
\end{tabular}

Uit tabel 8 komt naar voren dat zich onder degenen die mobiel zijn geworden niet alleen starters met een tijdelijk dienstverband bevinden, maar ook starters met een vaste aanstelling. Een vaste aanstelling alleen is blijkbaar onvoldoende reden om te blijven 'zitten waar je zit'. Van de starters met een vaste aanstelling is namelijk $33 \%$ toch van werkgever veranderd; bij de starters met een tijdelijk dienstverband is het percentage wel hoger, namelijk 57.

De vergelijking die in tabel 8 is gemaakt tussen de intredefunctie en de huidige functie laat zien dat de intrede in het beroepsleven en het verloop van de beroepscarrière wordt gedomineerd door een loopbaanpatroon waarbij men in een tijdelijke baan start en, ook na van functie te zijn veranderd, van tijdelijke banen afhankelijk blijft. Bij driekwart van de recent afgestudeerde academici verloopt de loopbaan volgens dit stramien. De academici die hun loopbaan in een vaste baan starten blijven meestal in vaste banen werken. Een aantal academici $(10 \%)$ slaagt er evenwel in om, vanuit een tijdelijke intredebaan, een vaste baan te verwerven.

De meeste academici starten hun loopbaan in full-time functies (meer dan 34 uur per week). In de loop van hun beroepscarrière gaan academici vaker voltijdfuncties uitoefenen. Uit de enquêteresultaten blijkt dat het aandeel van voltijdfuncties toeneemt van $75 \%$ in de intredebaan tot $81 \%$ in de huidige baan.

De meerderheid start de loopbaan in een full-time functie en blijft na al dan niet van functie te zijn veranderd in een full-time functie werken. Mobiliteit leidt doorgaans niet tot verandering van de werktijdfactor. Waar dit wel het geval is domineert de overgang van werken in deeltijd naar 
werken in voltijd.

Tabel 9. Verschuivingen in werktijdfactor tijdens de loopbaan (in \%)

Niet mobielen

Full-time

Full-time

Part-time

Mobielen

Full-time

Full-time

Part-time

Part-time

Totaal n (=100\%)

$\begin{array}{lr}\text { Full-time } & 27 \\ \text { Part-time } & 1 \\ \text { Part-time } & 5 \\ & \\ \text { Full-time } & 43 \\ \text { Part-time } & 5 \\ \text { Part-time } & 8 \\ \text { Full-time } & 11 \\ & \\ & 503\end{array}$

\subsection{Verandering van functie-niveau}

Eventuele veranderingen in het niveau van de functie als gevolg van mobiliteit worden vanuit twee invalshoeken benaderd. Eerst door na te gaan of al dan niet leiding wordt gegeven en vervolgens door het genoten inkomen te beschouwen.

\section{Leidinggeven}

Tabel 10. Verschuivingen in leidinggeven tijdens de loopbaan (in \%)

Intredefunctie leidinggevend?

Mobielen ja

ja

nee

nee
Huidige functie leidinggevend

$\begin{array}{rr}\text { ja } & 8 \\ \text { nee } & 24 \\ \text { ja } & 7 \\ \text { nee } & 5 \\ \text { nee } & 38 \\ \text { ja } & 18\end{array}$

Totaal n (=100\%)

Pas afgestudeerde academici die hun loopbaan in een leidinggevende functie starten zijn eerder uitzondering dan regel. Wel komen academici in de loop van hun beroepscarrière steeds vaker in 
leidinggevende functies terecht. Dit wordt bevestigd door de enquêteresultaten die in tabel 10 zijn weergegeven. Volgens deze resultaten neemt het aandeel dat leiding geeft per saldo toe met 14 procentpunt, van $20 \%$ in de intredefunctie tot $34 \%$ in de huidige functie. Hierbij sluit de bevinding aan dat mobiliteit vaker een overgang betekent van een niet-leidinggevende functie naar een leidinggevende functie dan omgekeerd.

\section{Inkomen}

Aan degenen die een betaalde functie uitoefenen is gevraagd naar de hoogte van het brutoinkomen per maand bij een volledige werkweek lexclusief toeslagen voor overwerk, dertiende maand, vakantiegeld en dergelijke). In de vragenlijst zijn 9 inkomensklassen onderscheiden, waarvan de laagste en de hoogste 'open' zijn (zie bijlage 4).

Deze 9 inkomensklassen zijn ten behoeve van deze analyse oplopend genummerd van 1 tot en met 9. Vervolgens is het rekenkundige gemiddelde vastgesteld. Uiteraard mag aan de grootte van de verschuivingen, die door deze ruwe transformatie zichtbaar worden, geen absolute betekenis worden toegekend.

In de loop van de -uiteraard nog korte- beroepscarrière blijkt het inkomen van de onderzochte academici te stijgen. Het gemiddelde inkomensklassenummer neemt met 0,8 toe van 4,5 in de intredebaan tot 5,3 in de huidige baan. Bij deze toename kunnen zowel leeftijdeffecten als mobiliteitseffecten een rol hebben gespeeld. De toename kan namelijk het gevolg zijn van periodieke salarisverhogingen op grond van anciënniteit (leeftijdeffect), maar kan ook resulteren uit veranderingen van functie (mobiliteitseffect).

Tabel 11. Mobiliteit en inkomensstijging

\begin{tabular}{lcccc}
\hline & & \multicolumn{2}{c}{ Toename van de inkomensklasse } \\
Cohort & $\%$ mobiliteit & Met mobiliteit & Zonder mobiliteit & Totaal \\
\hline 1988 & 57 & 0,5 & 0,4 & 0,5 \\
1987 & 67 & 1,0 & 0,3 & 0,8 \\
1986 & 77 & 1,2 & 0,2 & 0,9 \\
Totaal & 65 & 1,0 & 0,3 & 0,8 \\
\hline
\end{tabular}

Uit tabel 11 komt naar voren dat voor de inkomensstijging primair het mobiliteitseffect verantwoordelijk is. Bij iedere jaargang afgestudeerden is de inkomensstijging immers groter onder degenen die van functie zijn veranderd (mobiliteitseffect), dan onder degenen die niet 
mobiel zijn geweest (leeftijdeffect). Hierbij dient erop te worden gewezen dat het startsalaris nagenoeg gelijk was bij degenen die mobiel waren en bij degenen die niet van functie veranderden. Bijgevolg wordt mobiliteit niet bepaald door de hoogte van het inkomen dat men in de startpositie heeft. De bevinding dat mobiliteit tot een grotere inkomensstijging leidt kan er op duiden dat wel de vooruitzichten op een hoger inkomen een rol spelen bij mobiliteit.

Uit tabel 11 komt verder naar voren dat de omvang van de mobiliteit toeneemt naarmate men langer op de arbeidsmarkt verblijft. Het tempo waarin de mobiliteit toeneemt vlakt echter af. Hieruit kan worden geconcludeerd dat de meeste functiewisselingen in het begin van de beroepsloopbaan plaatsvinden. Naarmate men langer op de arbeidsmarkt verblijft neemt niet alleen de mobiliteit toe maar ook het salaris. Door de genoemde samenhang tussen inkomensstijging en mobiliteit is de toename van het salaris bij deze subpopulatie het grootst in de beginfase van de loopbaan, waar de meeste functiewisselingen plaatsvinden, en zwakt daarna af.

\subsection{Verandering in de aansluiting met de gevolgde studie}

In deze paragraaf wordt getracht inzicht te geven in de verschuivingen in de aansluiting van de uitgeoefende functie met de gevolgde studie die resulteren uit mobiliteit. Dit gebeurt aan de hand van het niveau en de richting van de voor de functie vereiste opleiding. Hiervan geeft tabel 12 beeld.

Tabel 12. Verschuivingen in vereiste opleiding tijdens de loopbaan (in \%)

Niet-mobielen

lager dan WO

niet-specifiek WO

specifiek WO

Mobielen

lager dan wo

lager dan WO

lager dan WO

niet-specifiek WO

niet-specifiek WO

niet-specifiek WO

specifiek WO

specifiek WO

specifiek WO

Totaal $n(=100 \%)$

$\begin{array}{lr}\text { lager dan WO } & 6 \\ \text { niet-specifiek WO } & 10 \\ \text { specifiek-WO } & 16 \\ & \\ \text { lager dan WO } & 5 \\ \text { specifiek WO } & 6 \\ \text { niet-specifiek WO } & 3 \\ \text { niet-specifiek WO } & 9 \\ \text { lager dan WO } & 2 \\ \text { specifiek WO } & 5 \\ \text { specifiek WO } & 33 \\ \text { niet-specifiek WO } & 3 \\ \text { lager dan WO } & 2\end{array}$


Met betrekking tot de intrede in het arbeidsbestel en het verloop van de beroepscarrière zijn onder de onderzochte afgestudeerden vier verschillende patronen te onderscheiden. Het meest voorkomende loopbaanpatroon, is dat van de "specialisten". Zij starten in een functie waarvoor de gevolgde studierichting specifiek is vereist en zij blijven in deze functie werken, of zetten na van functie te zijn veranderd de loopbaan in een qua opleidingsrichting aansluitende functie voort. Bij bijna de helft van de recent afgestudeerden verloopt de loopbaan volgens dit patroon. Het tweede loopbaanpatroon is dat van de "generalisten". Zij starten in een functie waarvoor de gevolgde studierichting niet specifiek is vereist en zetten hun loopbaan, al dan niet na verandering van functie, in een niet-aansluitende functie voort. Dit is bij circa énvijfde deel van de respondenten het geval. Het derde loopbaanpatroon is dat van "onderbenutting". Hierbij start men in een functie die onder academisch niveau ligt en zet deze, al dan niet na verandering van functie, in een dergelijk functieniveau voort. Dit is bij ruim $10 \%$ van de academici het geval. Een aantal academici $(9 \%)$ slaagt er evenwel in om, vanuit een intredefunctie die onder hun opleidingsniveau ligt, toch een baan op academisch niveau te verwerven.

\subsection{Samenvatting}

Gezien de uiteraard nog korte beroepsloopbaan van de respondenten, die minimaal één en maximaal vier jaar geleden zijn afgestudeerd, is het niet verwonderlijk dat bijna $40 \%$ na afstuderen nog slechts bij éen werkgever in éen functie heeft gewerkt. Degenen die wel mobiel zijn geweest, zijn vaker veranderd van werkgever (baanmobiliteit) dan van functie bij dezelfde werkgever (functiemobiliteit).

De intrede van academici op de arbeidsmarkt en het verloop van de beroepscarrière wordt gedomineerd door een loopbaanpatroon waarbij men in een tijdelijke baan start en, ook na van functie te zijn veranderd, van tijdelijke banen afhankelijk blijft. Een aantal academici slaagt er evenwel in om, vanuit een tijdelijke intredebaan, een vaste baan te verwerven. De meeste academici starten hun loopbaan in een full-time functie en blijven, na al dan niet van functie te zijn veranderd, in full-time functies werken.

Pas afgestudeerde academici die hun loopbaan in een leidinggevende functie starten zijn eerder uitzondering dan regel. Wel komen steeds meer academici in de loop van hun beroepscarrière in leidinggevende functies terecht.

In de loop van de nog korte beroepscarrière van de onderzochte academici neemt het inkomen toe, vooral via het veranderen van baan. Door de samenhang tussen inkomensstijging en mobiliteit is de toename van het inkomen het grootst in de beginfase van de loopbaan, waar de 
meeste functiewisselingen plaatsvinden.

Wat de aansluiting van de functie met de gevolgde studie betreft, is het meest voorkomende loopbaanpatroon dat van de 'specialisten'. Zij starten hun loopbaan in een functie waarvoor de gevolgde studierichting specifiek is vereist en blijven, na al dan niet van functie te zijn veranderd, in een qua opleidingsrichting aansluitende functie werken.

Geconstateerd kan worden dat een aantal oud-studenten via mobiliteit terecht is gekomen in stabielere banen, in hogere functies en in functies die beter aansluiten bij de gevolgde studie. 


\section{KENMERKEN VAN DE HUIDIGE FUNCTIE}

\subsection{Inleiding}

In dit hoofdstuk wordt ingegaan op de betaalde functies waarin de oud-studenten op het moment van enquêteren werkzaam zijn. De functies worden getypeerd aan de hand van de werkorganisaties waarin men terecht is gekomen, het beroep dat men uitoefent, het functieniveau en de aansluiting met de genoten opleiding.

De typering van de huidige functie heeft bij de verschillende subpopulaties die zijn benaderd als volgt plaatsgehad. Bij de populatie die met behulp van de standaard basisvragenlijst is benaderd $(n=555)$ betreft de typering de huidige functie, dit wil zeggen de functie van degenen die op het moment van bevraging betaald werk verrichten $(n=408$ ). Bij de populatie die met behulp van de retrospectieve basisvragenlijst is benaderd $(n=545)$ betreft het de huidige functie, indien men op het moment van bevraging betaald werk verricht $(n=490)$ of de laatste functie, indien men op het moment van bevraging niet langer betaald werkzaam is $(n=30)$. De beschrijving van de werkorganisatie heeft dus betrekking op alle oud-studenten die op het moment van de bevraging een betaalde baan hebben $(82 \%)$ en op het deel van de retrospectief bevraagde oudstudenten dat betaald héeft gewerkt (3\%).

Eerst wordt bekeken in welke organisaties men thans werkzaam is en welke werkzaamheden men daar verricht. De werkorganisaties worden beschreven naar grootte, geografische lokatie en bedrijfssector. Het werk wordt getypeerd aan de hand van het beroep dat men uitoefent. Vervolgens wordt het niveau van de huidige functie behandeld. Het niveau van de functie wordt hierbij vanuit drie invalshoeken benaderd. Eerst door na te gaan of al dan niet leiding wordt gegeven, vervolgens door het genoten inkomen te beschouwen en tenslotte door te kijken naar het niveau van de voor de functie vereiste opleiding.

Aan de hand van het vereiste opleidingsniveau en de vereiste opleidingsrichting kan tevens de aansluiting van de uitgeoefende functie op de gevolgde studie inzichtelijk worden gemaakt. Tenslotte wordt kort stil gestaan bij het niveau en de richting van het eventueel gevolgde onderwijs na het afstuderen. Dit onderwijs wordt gedifferentieerd naar het niveau en de richting van de opleiding die voor de uitoefening van de functie is vereist. 


\subsection{Grootte en lokatie van de werkorganisatie}

\section{Grootte}

In de enquête is gevraagd hoeveel mensen er werken in de vestiging van het bedrijf of de instelling waarbinnen men de huidige functie uitoefent. Uit tabel 6 in bijlage 1 komt naar voren dat de meeste afgestudeerden voor hun werkgelegenheid zijn aangewezen op grote bedrijven/instellingen (vestigingen met honderd of meer werknemers). Kleine vestigingen met minder dan tien werknemers zijn in dit verband het minst van belang.

Vooral economen komen vaak in grote organisaties terecht. Basisartsen en juristen werken iets vaker dan anderen in kleine organisaties, zoals huisartsenpraktijken en advocatenkantoren. Met betrekking tot dit aspect doen zich geen significante verschillen tussen mannen en vrouwen voor en evenmin tussen de drie nader beschouwde afstudeerrichtingen binnen gezondheidswetenschappen.

\section{Lokatie}

In de enquête is ook gevraagd naar de naam en het adres van de instelling, de praktijk of het bedrijf waar of van waaruit men werkt. Het gaat hierbij om de vestiging waar men thans werkzaam is. Met behulp van deze vraag wordt niet alleen een actueel adressenbestand van werkgevers gegenereerd, maar wordt ook een indicatie verschaft voor de bijdrage die de RL levert aan de groei van het op de regionale arbeidsmarkt aanwezige menselijke kapitaal.

In tabel 7 in bijlage 1 komt naar voren dat een substantieel deel van de alumni van de RL terecht komt op de Limburgse arbeidsmarkt. Ruim de helft werkt in de provincie Limburg, met name in het zuidelijk deel van de provincie (ongeveer een kwart werkt in Maastricht). Het is de vraag hoe snel een dergelijk kleine regionale arbeidsmarkt verzadigd zal zijn. Ondanks de Euregionale ligging van Maastricht werkt slechts éen op de twintig oud-studenten van de RL in het buitenland, dit wil zeggen in andere landen binnen Europa en andere werelddelen.

Van alle oud-studenten komen juristen nog het meest terecht op de Limburgse arbeidsmarkt, gezondheidswetenschappers en economen op de landelijke arbeidsmarkt en basisartsen in het buitenland (voornamelijk in het kader van ontwikkelingssamenwerking). De bevinding dat juristen zich sterk op deze kleine regionale markt richten vormt wellicht mede een verklaring voor hun lange intredewerkloosheid. Binnen de groep gezondheidswetenschappers zijn het vooral de afgestudeerden in BB die zich landelijk oriënteren $170 \%$ werkt in provincies buiten 
Limburg). Zowel bij verplegingswetenschappers als bij oud-studenten GVO bedraagt het percentage dat buiten Limburg werkt 51 .

Afgaande op de vestigingsplaats van de werkorganisatie, hebben vrouwen zich meer dan mannen op regio's buiten Limburg georiënteerd: $50 \%$ van de vrouwen en $40 \%$ van de mannen werkt buiten Limburg.

\section{Herkomst en regionale oriëntatie}

De RL heeft, evenals de meeste universiteiten, een regionaal zwaartepunt in het recuteringsgebied van haar afgestudeerden. Als nu een relatief groot deel van haar afgestudeerden uit de provincie Limburg afkomstig is en deze zich relatief sterk op de provinciale arbeidsmarkt oriënteert, kunnen verzadigingsproblemen ontstaan op de regionale arbeidsmarkt. Deze veronderstelling lijkt op het eerste gezicht te worden bevestigd. Van de respondenten is $69 \%$ afkomstig uit de provincie Limburg. Van de Limburgers met een betaalde baan is $54 \%$ in Limburg gaan werken, terwijl dit percentage bij de niet-Limburgers 46 is. Uit onderstaand overzicht blijkt echter dat de iets sterkere oriëntatie van de Limburgers op de Limburgse arbeidsmarkt vooral een gevolg is van de specifieke keuze van de studierichting.

Herkomstcategorie van de betaald werkenden

Limburgse basisartsen

Niet-Limburgse basisartsen

Totaal basisartsen

Limburgse gezondheidswetenschappers

Niet-Limburgse gezondheidswetenschappers

Totaal gezondheidswetenschappers

Limburgse juristen

Niet-Limburgse juristen

Totaal juristen

Limburgse economen

Niet-Limburgse economen

Totaal economen
\% dat in Limburg werkt

$$
\begin{aligned}
& 54 \\
& 59 \\
& 55 \\
& \\
& 42 \\
& 41 \\
& 42 \\
& \\
& 70 \\
& 71 \\
& 70 \\
& \\
& 50 \\
& 78 \\
& 57
\end{aligned}
$$

In het overzicht zijn de percentages van elke herkomstcategorie die in Limburg werkt uitgesplitst naar studierichting. Het blijkt dat deze percentages voor gezondheidswetenschappers en juristen niet significant verschillen. Bij de basisartsen en de economen oriënteert zelfs een groter deel van de niet-Limburgers zich op de provinciale arbeidsmarkt dan van de Limburgers. Het resultaat bij de economen zegt echter weinig door hun geringe aantal. 


\subsection{Branche en beroep}

\subsubsection{Bedrijfstak en beroepssector}

De werkorganisaties en het beroep waarin de afgestudeerden werkzaam zijn worden zowel getypeerd op het hoogste aggregatieniveau dat het CBS hanteert, namelijk op het niveau van bedrijfstak- en beroepssector (par. 7.3.1), als op het laagste aggregatieniveau, namelijk dat van bedrijfssubgroepen en beroepen (par. 7.3.3). Daarnaast worden flexibiliteitsindicatoren gepresenteerd die een indruk geven van de uitwijkmogelijkheden naar andere bedrijfssectoren en beroepen die afgestudeerden van de verschillende studierichtingen hebben (par. 7.3.2).

\section{Bedrijfstak}

In deze subparagraaf wordt nader ingegaan op de organisaties waarbinnen de oud-studenten, na al dan niet van werkorganisatie te zijn veranderd, thans werken. In paragraaf 6.1 , waarin de omvang van de baanmobiliteit na afstuderen werd besproken, kwam naar voren dat van alle onderzochte oud-studenten $12 \%$ nooit betaald heeft gewerkt, $47 \%$ in én werkorganisatie heeft gewerkt en $38 \%$ van werkorganisatie is veranderd. De beschrijving van de huidige werkorganisatie heeft dus in de meeste gevallen betrekking op de eerste baan na afstuderen.

Tabel 13. Betaald werkende oud-studenten naar bedrijfstak (in \%)

\begin{tabular}{|c|c|c|c|c|c|}
\hline \multirow[b]{2}{*}{ Bedrijfstak } & \multirow[b]{2}{*}{ FdG } & \multicolumn{2}{|c|}{ Oud-studenten van de } & \multirow[b]{2}{*}{ FdEW } & \multirow[b]{2}{*}{ Totaal } \\
\hline & & FdGW & FdR & & \\
\hline Industrie & 2 & 5 & 5 & 21 & 5 \\
\hline Handel, horeca & 0 & 1 & 5 & 0 & 2 \\
\hline $\begin{array}{l}\text { Bank- en verzekeringswezen, } \\
\text { zakelijke dienstverlening }\end{array}$ & 1 & 9 & 42 & 45 & 17 \\
\hline Niet-zakelijke dienstverlening & 97 & 83 & 48 & 29 & 76 \\
\hline Overige bedrijfstakken & 0 & 1 & 1 & 5 & 1 \\
\hline Totaal $n(=100 \%)$ & 303 & 334 & 258 & 38 & 933 \\
\hline
\end{tabular}

Uit tabel 13, waarin de afgestudeerden naar bedrijfstak en studierichting zijn weergegeven, komt naar voren dat basisartsen en gezondheidswetenschappers voor een baan vrijwel uitsluitend zijn aangewezen op de niet zakelijke dienstverlening (met name gezondheidsdiensten). De overgrote meerderheid van de betaald werkende juristen komt terecht in de zakelijke en nietzakelijke dienstverlening. Zij zijn in vrijwel gelijke mate aangewezen op de zakelijke 
dienstverlening (met name rechtskundige diensten) als op de niet-zakelijke dienstverlening (met name openbaar bestuur en universiteiten). De belangrijkste bron van werkgelegenheid voor de economen bestaat uit de zakelijke dienstverlening (met name accountantsbureaus). De nietzakelijke dienstverlening en de industrie zijn voor hen in nagenoeg gelijke mate iets minder belangrijk.

\section{Beroepssector}

In tabel 14 wordt aangegeven in welke beroepssectoren oud-studenten terecht zijn gekomen. Voor de interpretatie van deze gegevens is van belang dat van de respondenten die vóór juli 1988 afstudeerden bijna tweederde al eens van functie is veranderd en dat functieverandering in $62 \%$ van de gevallen gepaard is gegaan met verandering van beroep. Uit tabel $14 \mathrm{komt}$ naar voren dat de meeste oud-studenten een wetenschappelijke of andere vakspecialistische functie uitoefenen. Basisartsen werken vrijwel uitsluitend in dit soort functies. Gezondheidswetenschappers komen daarnaast ook wel in beleidvoerende functies terecht. Juristen en vooral economen oefenen ook administratieve functies uit.

Tabel 14. Betaald werkende oud-studenten naar beroepssector (in \%)

\begin{tabular}{lrrrrr}
\hline Beroepssector & FdG & $\begin{array}{l}\text { Oud-studenten van de } \\
\text { FdGW }\end{array}$ & FdR & FdEW & Totaal \\
\hline $\begin{array}{l}\text { Wetenschappelijke en andere } \\
\text { vakspecialistische functies }\end{array}$ & 98 & 76 & 75 & 53 & 82 \\
$\begin{array}{l}\text { Beleidvoerende en hogere } \\
\text { leidinggevende functies }\end{array}$ & 1 & 16 & 4 & 8 & 8 \\
$\begin{array}{l}\text { Administratieve functies } \\
\text { Commerciële functies }\end{array}$ & 0 & 5 & 16 & 39 & 8 \\
Dienstverlenende functies & 0 & 3 & 3 & 0 & 2 \\
Totaal $n(=100 \%)$ & 0 & 1 & 1 & 0 & 1 \\
\hline & 303 & 331 & 256 & 38 & 928 \\
\hline
\end{tabular}

\subsubsection{Branche- en beroepenspreiding van RL-studierichtingen}

\section{Gini-Hirschman coëfficiënt}

Voor de studierichtingen geneeskunde, Nederlands recht en economie, alsmede voor de afstudeerrichtingen BB, GVO en VW van de studierichting gezondheidswetenschappen, zijn indicatoren berekend voor de uitwijkmogelijkheden naar andere beroepsklassen, die deze studie/afstudeerrichtingen bieden (de beroepenspreiding). Analoog aan deze indicator is voor de 
verschillende studies ook een indicator berekend voor de uitwijkmogelijkheden naar andere bedrijfsgroepen, (de branchespreiding). Voordat de resultaten worden besproken zal eerst nader worden ingegaan op de Gini-Hirschman coëfficiënt ${ }^{20}$, die als indicator is gebruikt voor de genoemde uitwijkmogelijkheden.

De opvatting dat er een directe en exclusieve relatie bestaat tussen opleidingen en beroepen wordt door Van Hoof en Dronkers bekritiseerd (1980). Dit naïeve model van de arbeidsmarkt negeert ten onrechte de bestaande flexibiliteit in de aansluiting van opleidingen en beroepen. Schoolverlaters met een bepaalde opleiding kunnen in geheel verschillende beroepen terecht komen en veel beroepen worden uitgeoefend door afgestudeerden met een geheel verschillende opleidingsachtergrond. Het naïeve model impliceert dat een betere aansluiting tussen onderwijs en arbeidsmarkt kan worden bewerkstelligd door de scholing van het arbeidsaanbod perfect te laten aansluiten op de kwalificaties die op de arbeidsmarkt worden gevraagd. Volgens het flexibiliteitsmodel dat Van Hoof en Dronkers naar voren brengen is veeleer een verbreding van het kwalificatieprofiel van de schoolverlaters het aangewezen middel om de aansluiting tussen onderwijs en arbeidsmarkt te verbeteren. In dat geval is het van groot belang om een indicatie te hebben van de flexibiliteit die schoolverlaters middels het gevolgde onderwijs hebben verkregen.

Een maatstaf die een indicatie geeft van de bestaande flexibiliteit op de arbeidsmarkt is de GiniHirschman coëfficiënt (GH) (Sheldon, 1985 en Warnken, 1986). Op basis van deze maatstaf kunnen de branchespreiding en de beroepenspreiding van de verschillende opleidingscategorieën worden bepaald. Het grote voordeel van deze indicator is, dat hij zeer makkelijk is te interpreteren. De indicator neemt waarden aan tussen 0 en 1 . De branchespreiding van opleidingen is 0 als de opleidingsrichting slechts in éen branche voorkomt en 1 als de opleidingsrichting gelijkmatig over alle branches is verspreid. Hetzelfde geldt voor de beroepenspreiding van opleidingen. Deze is 0 als de opleidingsrichting slechts in én beroep voorkomt en 1 als de opleidingsrichting over alle beroepen is verspreid.

De situaties van een exclusieve relatie tussen opleidingen en beroepen (coëfficiënt is 0 ) en van volledige flexibiliteit (coëfficiënt is 1 ) kunnen worden gezien als twee ideaaltypische extremen. Waarschijnlijker is echter dat de meeste beroepen en opleidingen zich ver van beide extremen bevinden. (zie De Grip en Heijke, 1989).

Bij de interpretatie van de hier weergegeven spreidingsindicatoren moet worden bedacht dat

20. Overgenomen uit: De Grip, van der Velden, Wieling (1991), blz. 22. 
deze niet betrekking hebben op de potentiële flexibiliteit, maar op de feitelijk opgetreden flexibiliteit van de oud-studenten.

\section{Beroepenspreiding van studie/afstudeerrichtingen}

De formule van de Gini-Hirschman coëfficiënt voor beroepen luidt als volgt:

$$
S O B_{k}=\left(1-\sum_{i=1}^{I} \gamma_{k i}^{2}\right) \frac{I}{I-1}
$$

Met: $S O B_{k}=$ Gini-Hirschman coëfficiënt beroepenspreiding van opleiding $\mathrm{k}$

$$
\begin{array}{ll}
\gamma_{k i} & =\text { aandeel opleiding } \mathrm{k} \text { werkzaam in beroep } \mathrm{i} \\
I & =\text { aantal beroepen }
\end{array}
$$

Er wordt enigszins gecorrigeerd voor het gekozen aggregatieniveau door middel van de correctieterm $\frac{I}{I-1}$.

In tabel 15 staan de volgens formule (1) berekende Gini-Hirschman coëfficiënten met betrekking tot de beroepenspreiding van de onderscheiden RL-richtingen. $\mathrm{Er}$ is bij de berekening van de spreidingsindicator uitgegaan van beroepsgroepen (3-digitniveau). Hierbij dient te worden opgemerkt dat de coëfficiënten de neiging hebben om snel te stijgen en bijgevolg een grote spreiding te suggereren. De reden hiervoor is dat de coëfficiënten hoger zullen zijn naarmate het niveau van de beroepen minder geaggregeerd is, omdat het aantal beroepen waarin de desbetreffende opleidingsrichting kan voorkomen bij een lager aggregatieniveau groter is. De in de formule opgenomen correctieterm corrigeert hier niet volledig voor. Aan de hoogte van een berekende spreidingsindicator mag derhalve geen absolute betekenis worden toegekend. Hij positioneert de desbetreffende opleidingsrichting ten opzichte van de andere RL-richtingen en zegt daarmee alleen iets over de relatieve spreiding over een doorgaans beperkt aantal beroepen die met een bepaalde opleiding worden uitgeoefend.

Uit tabel 15 (kolom 3) komt naar voren dat de spreidingscoëfficiënt voor geneeskunde duidelijk lager is dan voor de andere richtingen. De Gini-Hirschman coëfficiënt van deze richting wijst op een relatief kleine beroepenspreiding. In de afstudeerrichtingen BB en VW treedt daarentegen een grote beroepenspreiding op. Economie, Nederlands recht en GVO nemen hierbij een 
tussenpositie in. Resumerend ligt de relatie tussen opleiding en beroep voor basisartsen nog het dichtst bij het naïeve model en die voor oud-studenten BB en VW bij het flexibiliteitsmodel. Er kan als gevolg van de berekende resultaten worden geconcludeerd dat de relatie tussen opleidingen en beroepen voor met name juristen, economen en afgestudeerden GVO niet wordt getypeerd door het naïeve model, maar ook niet door een volledige flexibiliteit.

Tabel 15. De beroepsgroepenspreiding en het aandeel van werklozen van RL-studie/afstudeerrichtingen

\begin{tabular}{lcccc}
\hline Richting & SOB & 3) & $\begin{array}{l}\text { \% werkloze respon- } \\
\text { denten, volgens } \\
\text { CBS-definitie }\end{array}$ \\
& $1)$ & 21 & 0,27 & 4 \\
Geneeskunde & 0,19 & 0,26 & 5 \\
BB & 0,80 & 0,84 & 0,89 & 9 \\
GVO & 0,61 & 0,69 & 0,72 & 5 \\
VW & 0,80 & 0,84 & 0,89 & 18 \\
Nederlands recht & 0,73 & 0,75 & 0,78 & 5 \\
Economie & 0,67 & 0,78 & 0,75 & \\
\hline
\end{tabular}

1) Specifieke studierichting vereist

2) Ook niet-specifieke studierichtingen toegestaan

3) Ook opleidingen onder WO-niveau toegestaan

Mannen hebben doorgaans iets meer uitwijkmogelijkheden naar andere beroepen dan vrouwen. Dit komt met name bij de opleidingsrichting GVO naar voren. Hiervan geeft tabel 8 in bijlage 1 een beeld. Het verschil in uitwijkmogelijkheden naar andere beroepen tussen mannen en vrouwen bij deze richting hangt overigens niet samen met een eventueel verschil in werkloosheid, want het laatste is namelijk niet significant.

De onder kolom 3) in tabel 15 vermelde spreidingscoëfficiënten zijn berekend op basis van alle beroepen die door de oud-studenten op het moment van de enquête werden uitgeoefend. $\mathrm{Er}$ is daarbij geen rekening gehouden met de opleidingseisen van de banen waarnaar men uitwijkt. Het ligt voor de hand dat een afgestudeerde die aanvankelijk geen werk kan vinden dat op zijn studie aansluit, een baan zal aanvaarden die daar minder goed op aansluit. De discrepantie die in dat geval ontstaat kan betrekking hebben op de richting en/of op het niveau van het werk. Indien men echter voor de verschillende studierichtingen een uitspraak wil doen over de uitwijkmogelijkheden op de arbeidsmarkt, waarbij geen discrepanties naar niveau of richting optreden, moeten de functies waarvoor de desbetreffende studierichting niet specifiek is vereist ook niet worden meegenomen. Om hiervan een beeld te krijgen is de beroepenspreiding van opleidingsrichtingen ook bepaald door achtereenvolgens alleen te kijken naar functies waarvoor een opleiding op WO-niveau is vereist en functies waarvoor de desbetreffende WO- 
studierichting specifiek is vereist. De aldus berekende spreidingsindicatoren staan vermeld in tabel 15 onder respectievelijk de kolommen 2) en 1).

De spreidingscoëfficiënten voor de verschillende opleidingsrichtingen zijn inderdaad kleiner naarmate in het desbetreffende domein de functies beter aansluiten bij de gevolgde studierichting. Naarmate deze verschillen groter zijn zullen afgestudeerden van de desbetreffende studierichting die geen beroep kunnen vinden binnen het beroependomein waarvoor zij specifiek zijn opgeleid, vaker kunnen uitwijken naar beroepen die minder goed aansluiten bij de richting en het niveau van de gevolgde studie. De verschillen tussen de onderscheiden typen spreidingscoëfficiënten variëren evenwel nauwelijks tussen de verschillende studierichtingen. De relatief grootste uitwijkmogelijkheden buiten het specifieke beroependomein lijken te bestaan voor GVO en de kleinste voor Nederlands recht.

In tabel 15 zijn ook de procentuele aandelen weergegeven van de werklozen onder de onderzochte oud-studenten van de desbetreffende studie/afstudeerrichting. Het percentage werklozen en de spreidingscoëfficiënt kunnen op twee, tegengestelde, manieren met elkaar samenhangen $^{21}$. Ten eerste, kan een hoge spreidingscoëfficiënt wijzen op ruime uitwijkmogelijkheden, als gevolg waarvan de werkloosheid voor de betreffende opleiding laag zal zijn. De samenhang tussen de twee indicatoren zal in dit geval negatief zijn. Er kan echter ook een tegengestelde redenering worden gevolgd. Deze luidt dat een hoge werkloosheid in een bepaalde richting aanleiding geeft tot een grotere spreidingsgraad, omdat schoolverlaters die in hun 'eigen' beroependomein geen baan kunnen krijgen, in andere beroepen proberen werk te vinden. In dit geval is er sprake van een positieve samenhang tussen beide indicatoren.

Ten einde een beeld te krijgen van de vraag welke redenering nu actueel is, zijn in figuur 1 voor de zes onderscheiden studie-/afstudeerrichtingen het percentage werklozen en de spreidingsindicatoren ten aanzien van het "eigen" beroependomein tegen elkaar afgezet. De figuur wijst in de richting van een positieve samenhang tussen beide indicatoren voor de richting geneeskunde. Deze opleiding heeft namelijk zowel een laag werkloosheidspercentage als een lage Gini-Hirschman coëfficiënt. De verklaring hiervoor is waarschijnlijk dat er voldoende vraag is naar afgestudeerden van deze opleidingsrichting in hun "eigen" beroependomein. Oudstudenten met deze opleidingsrichting hoeven derhalve niet zo vaak uit te wijken naar andere beroepen. De hoge spreidingscoëfficiënt in combinatie met de lage werkloosheid voor de richtingen BB en VW wijst op veel uitwijkmogelijkheden zowel binnen als buiten het 'eigen' domein, waardoor de werkloosheidsgevoeligheid van de betreffende richtingen laag is. Beide

21. De Grip, van der Velden, Wieling (1991), blz. 26. 
indicatoren wijzen evenwel op een moeilijker arbeidsmarktpositie van de studierichting Nederlands recht. Ondanks de bevinding dat hun werkgelegenheid al over vrij veel beroepen veelal binnen het "eigen" beroependomein- is verspreid, is de werkloosheid onder juristen het hoogste. Mogelijk slagen zij er in onvoldoende mate in ook buiten het "eigen" beroependomein werk te vinden.

Figuur 1. Relatie tussen het aandeel van werklozen en de beroepenspreiding van de opleidingsrichtingen voor functies waarvoor de specifieke studierichting is vereist

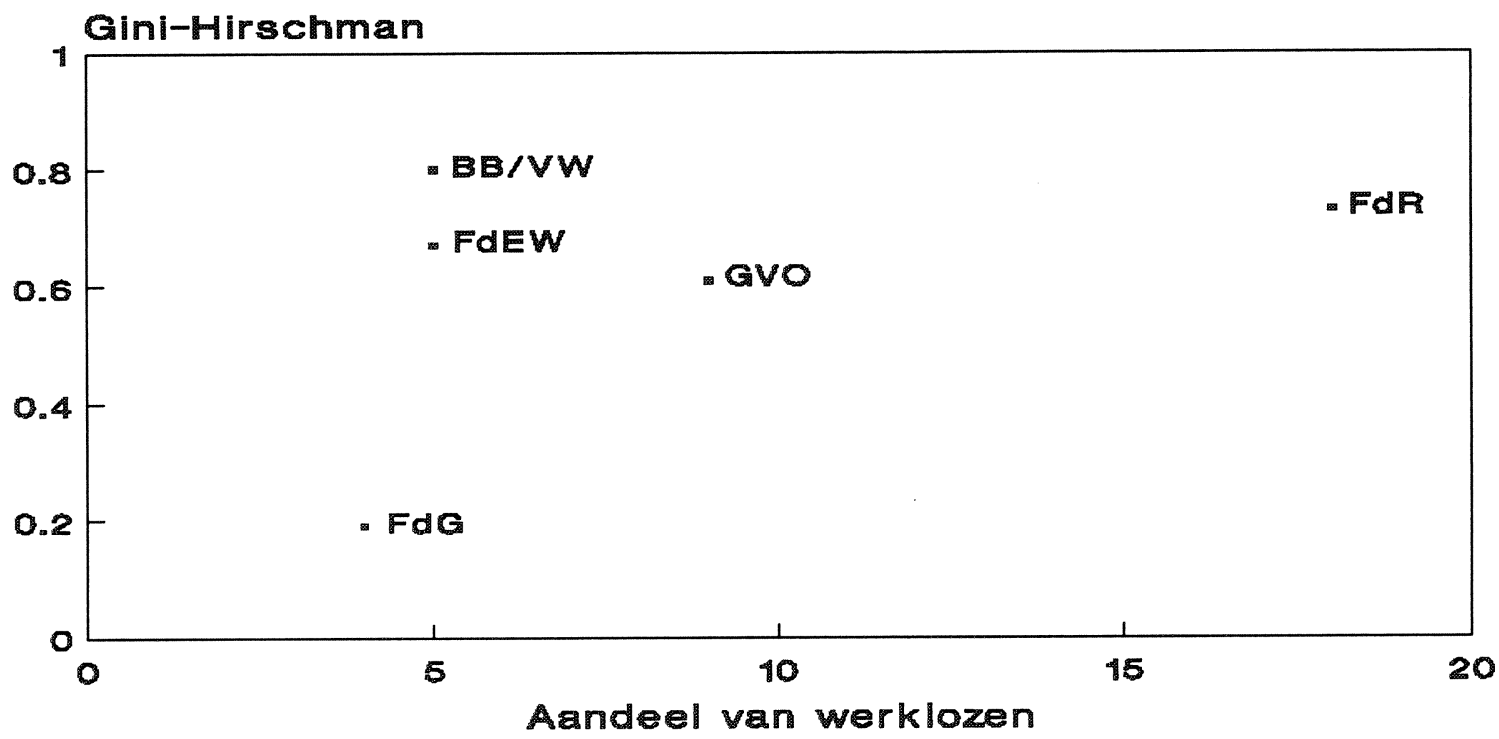

Branchespreiding van studie/afstudeerrichtingen

Wanneer de afgestudeerden van een bepaalde studierichting sterk geconcentreerd zijn in een beperkt aantal bedrijfsgroepen, zal de werkgelegenheidsontwikkeling van deze studierichting in belangrijke mate afhankelijk zijn van het wel en wee van deze bedrijfsgroepen. Om een indruk te krijgen van de bedrijfsgroepen waarin de oud-studenten terecht komen is, naast de beroepsgroepenspreiding van opleidingsrichtingen, ook de bedrijfsgroepenspreiding van opleidingsrichtingen bepaald. Hierbij is gebruik gemaakt van onderstaande formule, waarbij voor het gekozen aggregatieniveau wordt gecorrigeerd door middel van de correctieterm $J / J-1$. 
$S O B R_{k}=\left(1-\sum_{j=1}^{J} \beta_{k j}^{2}\right) \frac{J}{J-1}$

Met: $\operatorname{SOBR}_{k}=$ Gini-Hirschman coëfficiënt branchespreiding van opleiding $\mathrm{k}$

$\beta_{k j} \quad=$ aandeel opleiding $\mathrm{k}$ werkzaam in bedrijfsgroep $\mathrm{j}$

$J \quad=$ aantal bedrijfsgroepen

Bovenstaande branchespreiding van opleidingsrichtingen is bepaald voor bedrijfsgroepen (3digitniveau). De resultaten zijn weergegeven in tabel 16. De Gini-Hirschman coëfficiënten laten zien dat er weinig verschillen zijn in branche gevoeligheid tussen de opleidingsrichtingen.

Tabel 16. De bedrijfsgroepenspreiding van RL-studie/afstudeerrichtingen

\begin{tabular}{ll} 
Richting SOBR & SO \\
\hline
\end{tabular}

Geneeskunde

BB

GVO

VW

Nederlands recht

Economie
0,78

0,88

0,79

0,86

0,89

0,77

Eerder is opgemerkt dat mannen doorgaans iets meer uitwijken naar andere beroepen dan vrouwen. Met betrekking tot de branchespreiding doet zich de tegengestelde situatie voor, namelijk dat vrouwen door de bank genomen meer uitwijkmogelijkheden naar andere bedrijfsgroepen hebben dan mannen. Dit is met name bij de richtingen VW en geneeskunde het geval (zie tabel 8 in bijlage 1).

\subsubsection{Beroep en bedrijfssubgroep}

Hieronder wordt achtereenvolgens voor de studie- of afstudeerrichtingen nagegaan in welke beroepen en in welke bedrijfssubgroepen de oud-studenten werkzaam zijn. Zoals eerder is gemeld zijn de bedrijfssubgroepen gecodeerd op vier-cijferig niveau (bedrijfssubgroep-niveau) conform de Standaard Bedrijfsindeling van het CBS. Evenals de bedrijfssector is ook het beroep gecodeerd op vier-cijferig niveau. Hierbij is de CBS-beroepenclassificatie gevolgd.

De tabellen waarin cijfermatige gegevens worden gepresenteerd met betrekking tot de beroepen en de bedrijfssubgroepen zijn opgenomen in bijlage 1 . In de tabellen met de bedrijfssubgroepen worden alleen die groepen met naam genoemd waarbinnen tenminste $5 \%$ van de betaald 
werkende oud-studenten van de desbetreffende studie- of afstudeerrichting werkzaam zijn.

\section{Basisartsen}

Door de onderzochte basisartsen worden in totaal 19 verschillende beroepen uitgeoefend. De overgrote meerderheid $(85 \%)$ echter werkt in vijf beroepen die behoren tot de beroepsgroep 'geneeskundigen'.

De basisartsen zijn verspreid over 32 bedrijfssubgroepen werkzaam. De meeste werkgelegenheid $(78 \%)$ is geconcentreerd in 14 bedrijfssubgroepen die behoren tot de bedrijfsklasse 'gezondheidsdiensten'. Binnen deze bedrijfsklasse vormen de 'algemene en gespecialiseerde ziekenhuizen (excl. psychiatrische)' met $42 \%$ de belangrijkste bedrijfsgroep. De grootste bedrijfssubgroep zijn de 'algemene, niet-academische ziekenhuizen'. Hierin komt éénvijfde deel van de betaald werkende basisartsen terecht.

\section{Afgestudeerden $B B$}

De oud-studenten BB oefenen in totaal 33 beroepen uit. De meerderheid (63\%) is echter werkzaam in een van de volgende vijf beroepen: beleidsmedewerker, bedrijfsorganisatiedeskundige, administratieve automatiseringsdeskundige, econoom en sociaal-wetenschappelijk onderzoeker.

Van de drie nader beschouwde groepen gezondheidswetenschappers is deze groep met $76 \%$ nog het minst sterk op de kwartaire sector aangewezen en over het grootste aantal (31) bedrijfssubgroepen verspreid. De meeste werkgelegenheid is geconcentreerd in bedrijfssubgroepen die behoren tot de bedrijfsklassen 'gezondheidsdiensten' $(49 \%)$, 'onderwijs' (13\%), 'verzekeringswezen (10\%) en 'zakelijke dienstverlening' (eveneens $10 \%$ ).

\section{Afgestudeerden GVO}

Ondanks de bevinding dat de afgestudeerden GVO in totaal 21 verschillende beroepen uitoefenen, komt een kleine meerderheid (59\%) toch in slechts twee beroepen terecht: $41 \%$ werkt als medisch-maatschappelijk werker en $18 \%$ als sociaal-wetenschappelijk onderzoeker.

Voor een baan zijn de afgestudeerden GVO vrijwel uitsluitend (voor $90 \%$ ) aangewezen op de niet-zakelijke dienstverlening. Zij zijn verspreid over 17 bedrijfssubgroepen werkzaam. De meeste werkgelegenheid $(72 \%)$ is geconcentreerd in bedrijfssubgroepen die behoren tot de 
$-59-$

bedrijfsklassen 'gezondheidsdiensten' (45\%) en 'onderwijs' (27\%). Binnen deze twee bedrijfsklassen domineren de bedrijfssubgroepen medische en verpleegkundige diensten, samenwerkings- en adviesorganen op het gebied van de gezondheidszorg en universiteiten.

\section{Afgestudeerden VW}

Door de onderzochte oud-studenten VW worden in totaal 23 verschillende beroepen uitgeoefend. De meesten (64\%) werken echter in de volgende vijf beroepen: staffunctionaris verpleging, docent (para)medische vakken, sociaal-wetenschappelijk onderzoeker, (para)medisch-wetenschappelijk onderzoeker en medisch-beleidsmedewerker.

Ook oud-studenten VW zijn voor een baan vrijwel uitsluitend (voor $89 \%$ ) op de niet-zakelijke dienstverlening aangewezen. De werkgelegenheid, verspreid over 22 bedrijfssubgroepen, is evenals bij oud-studenten GVO geconcentreerd in de bedrijfsklassen 'gezondheidsdiensten' $(49 \%)$ en onderwijs (27\%). Binnen deze twee bedrijfsklassen domineren de bedrijfssubgroepen algemene, niet-academische ziekenhuizen en universiteiten.

\section{Juristen}

Meer dan de helft (59\%) van de onderzochte juristen oefent het beroep van jurist uit. De rest komt terecht in een breed scala van 34 beroepen, waarbinnen onderwijsfuncties $(11 \%)$ en administratieve functies $(16 \%)$ domineren.

De juristen zijn verspreid over 51 bedrijfssubgroepen. De meesten (69\%) zijn echter werkzaam in bedrijfssubgroepen die behoren tot de volgende drie bedrijfsklassen:

- 'zakelijke dienstverlening' (28\%), met name de bedrijfsgroep 'rechtskundige diensten' (23\%);

- 'openbaar bestuur' (21\%), met name de bedrijfsgroep 'algemene overheidsadministraties' (16\%);

- 'onderwijs' (20\%), met name de bedrijfssubgroep 'universiteiten' (14\%).

\section{Economen}

De onderzochte economen oefenen in totaal 12 verschillende beroepen uit. Bijna $70 \%$ werkt in de beroepsgroep 'economen' of oefent het beroep van assistent-accountant uit.

Economen zijn vooral werkzaam in de bedrijfstak industrie $(21 \%)$ en in de bedrijfsklassen 'zakelijke dienstverlening' (39\%) en 'onderwijs' (24\%). Binnen de zakelijke dienstverlening 
overheerst de bedrijfssubgroep accountantsbureaus en binnen het onderwijs de bedrijfssubgroep universiteiten (de RL).

\subsection{Niveau van de functie}

In deze paragraaf wordt nader ingegaan op een drietal indicatoren die iets zeggen over het niveau van de functie. Eerst wordt nagegaan of er al dan niet sprake is van een leidinggevende functie en vervolgens wordt het genoten inkomen beschouwd. Daarna komt het niveau van de werkzaamheden aan de orde. Indicaties voor het laatste worden verkregen door het voor de functie vereiste opleidingsniveau te beschouwen.

\section{Leidinggeven}

De meeste respondenten oefenen nog geen leidinggevende functie uit. Van degenen die wel een leidinggevende functie uitoefenen, geven de meesten leiding aan maximaal vier personen. Hiervan geeft tabel 15 in bijlage 1 een beeld. Deze resultaten zijn niet verwonderlijk aangezien het gaat om academici die pas één tot vier jaar geleden zijn afgestudeerd en bijgevolg aan het begin van hun beroepscarrière staan.

Van alle oud-studenten hebben basisartsen nog het meest vaak een leidinggevende functie. Ten aanzien van het al dan niet leidinggeven doen zich geen verschillen voor tussen de drie nader beschouwde afstudeervarianten van de FdGW.

Naarmate men langer op de arbeidsmarkt verblijft, neemt de kans toe dat men een leidinggevende functie uitoefent. Van jaargang ' 89 oefent nog slechts $17 \%$ een leidinggevende functie uit; bij jaargang ' 88 bedraagt het percentage 26, bij jaargang ' 8731 en bij jaargang ' 86 is het percentage al opgelopen tot 45 .

Mannen blijken significant vaker dan vrouwen in leidinggevende functies werkzaam te zijn. Van de mannen heeft $36 \%$ een leidinggevende functie; van de vrouwen 'slechts' $22 \%$. Bij dit verschil kan discriminatie van vrouwen op de arbeidsmarkt of zelfselectie een rol spelen. De bevinding in paragraaf 8.2 . dat vrouwen significant vaker in deeltijd werken kan wijzen in de richting van zelfselectie. 
Aan degenen die een betaalde functie uitoefenen is gevraagd naar de hoogte van het brutoinkomen per maand bij een volledige werkweek (exclusief toeslagen voor overwerk, dertiende maand, vakantiegeld en dergelijke). In de vragenlijst zijn 9 inkomensklassen onderscheiden, waarvan de laagste en de hoogste 'open' zijn (zie bijlage 4) ${ }^{22}$. Tabel 16 in bijlage 1 geeft een beeld van het bruto maandinkomen in de huidige functie. Hieruit komt naar voren dat $38 \%$ een bruto maandinkomen (bij een normale werkweek) verwerft dat ligt binnen de modale inkomensklasse van $f 3.750,---f 5.000,--$. De inkomensspreiding is dus groot.

Met behulp van regressie-analyse is gepoogd om variabelen te identificeren die een verklaring vormen voor de hoogte van het bruto inkomen per maand bij een volledige werkweek. Ten behoeve van de regressie-analyse is aan de waarnemingen die vallen binnen de zeven 'gesloten' inkomensklassen de waarde toegekend van het desbetreffende klassenmidden. Hierbij zijn de waarnemingen die vallen in de hoogste ('open') inkomensklasse toegerekend tot de hoogste gesloten klasse. Bij de laagste ('open') inkomensklasse is de hoogste waarde gebruikt, die $f$ $1.500,--$ bruto per maand bedraagt. Dit komt ongeveer neer op het wettelijk minimumloon. Het voorgaande betekent dat het bruto maandinkomen in de analyse de volgende waarden kan aannemen:

$f 1.500,--f 1.750,--f 2.250,--f 2.750,--f 3.375,--f 4.375,--f 6.250,--f 10.000,--{ }^{23}$.

In de regressie-vergelijking zijn als verklarende variabelen voor de hoogte van het bruto maandinkomen drie achtergrondkenmerken en acht baan-gerelateerde kenmerken opgenomen. De achtergrondkenmerken betreffen het geslacht, de gevolgde opleidingsrichting en het aantal jaren geleden dat men is afgestudeerd. De baan-gerelateerde kenmerken hebben betrekking op eventuele baanmobiliteit, het niveau van de functie (het niveau van de vereiste opleiding en het al dan niet leidinggeven), de zekerheid van de baan en de lengte van de werkweek, de werkorganisatie (grootte en branche) en het al dan niet combineren werken en leren tijdens de functie-uitoefening. Voor deze verklarende variabelen zijn dummies geconstrueerd, behoudens voor het aantal jaren geleden dat men is afgestudeerd. De dummy-variabelen hebben betrekking op de gevolgde studierichting (geneeskunde, economie en rechten) of de afstudeerrichting binnen gezondheidswetenschappen (BB, GVO en VW), het veranderd zijn van werkgever (baanmobiliteit), mannelijk geslacht (geslacht), werken in een grote arbeidsorganisatie

22. In het vervolg zal ook worden gevraagd naar de exacte hoogte van het inkomen.

23. Dezelfde analyse, verricht na een logaritmische transformatie van de inkomenswaarden, leidde niet tot andere analyseresultaten. 
(bedrijfsomvang), werken in de profit-sector (branche), een aanstelling voor onbepaalde tijd (baanzekerheid), een full-time baan (werktijdfactor), het uitoefenen van een leidinggevende functie (leiding), het uitoefenen van een functie waarvoor een academische opleiding is vereist (niveau-eis) en het combineren van werken en leren binnen de functie (combi). Voor een precieze omschrijving en codering van deze dummy-variabelen wordt verwezen naar bijlage 3.

Wat de achtergrondkenmerken betreft, wordt verondersteld dat het inkomen verschilt naar opleidingsrichting, dat vrouwen in verband met mogelijke discriminatie op de arbeidsmarkt een lager inkomen zullen hebben en dat het inkomen zal toenemen naarmate men langer geleden is afgestudeerd. Wat de baankenmerken betreft, wordt verwacht dat:

- $\quad$ van baanverandering een positief effect zal uitgaan op het inkomen;

- een hoger functieniveau (het uitoefenen van een functie op academisch niveau en het werken in een leidinggevende functie) zal leiden tot een hoger inkomen;

- een stabiele baan, tot uiting komend in een aanstelling voor onbepaalde tijd en een fulltime functie een positief effect heeft op het maandinkomen bij een volledige werkweek;

- het particuliere bedrijfsleven beter betaalt dan de overheid en grote bedrijven beter betalen dan het midden- en kleinbedrijf;

- 'on the job' leren moet worden gezien als een investering in menselijk kapitaal waar nu weliswaar een lager inkomen tegenover staat, maar die later zal leiden tot een hoger inkomen.

$\mathrm{Er}$ is een regressievergelijking geschat met alle hiervoor genoemde (dummy) variabelen. Hierbij fungeren de andere afstudeerrichtingen binnen gezondheidswetenschappen dan BB, GVO en VW als referentiecategorie voor de gevolgde opleidingsrichting. De schattingsresultaten van deze regressievergelijking zijn vermeld in tabel 17. De regressiecoëfficiënten geven aan met hoeveel gulden het bruto maandinkomen toeneemt als de betreffende verklarende (dummy)variabele 1 wordt. De desbetreffende t-waarden staan eveneens vermeld.

De in de regressievergelijking meegenomen variabelen verklaren gezamenlijk slechts $22 \%$ van de variantie in het inkomen. Afgestudeerden geneeskunde en oud-studenten BB verdienen een significant hoger inkomen dan de referentiecategorie. Voor basisartsen wordt het verschil geschat op bijna $f$ 1000,-- bruto per maand en voor afgestudeerden BB op ruim $f 400,--$ bruto per maand. Voor de andere afgestudeerden blijkt de gevolgde opleidingsrichting niet van invloed te zijn op de hoogte van het inkomen. In de analyse komt verder naar voren dat het aantal jaren dat men reeds is afgestudeerd van invloed is op de hoogte van het huidige inkomen. leder additioneel jaar op de arbeidsmarkt brengt bruto ruim $f 200$,-- extra per maand op. 
Uit tabel 16 in bijlage 1 komt naar voren dat mannen meer dan vrouwen in de hogere inkomensklassen terecht komen. Dit verschil is toe te schrijven aan de autonome invloed van de factor geslacht. In de regressievergelijking komt naar voren dat mannen bruto $f 260$,-- meer per maand verdienen dan vrouwen.

Tabel 17. Resultaten regressie-analyse bruto maandinkomen

\begin{tabular}{lcc}
\hline & regressiecoëfficiënt & t-waarde \\
\hline Constante & $2318,89^{* *}$ & 11,23 \\
Geneeskunde & $984,57^{* *}$ & 5,49 \\
BB & $417,45^{*}$ & 2,06 \\
GVO & 24,47 & 0,11 \\
VW & 140,48 & 0,62 \\
Rechten & 65,14 & 0,37 \\
Economie & 18,64 & 0,07 \\
Cohort & $216,69^{* *}$ & 4,92 \\
Baanmobiliteit & 77,55 & 0,86 \\
Geslacht & $266,05^{* *}$ & 2,89 \\
Bedrijfsomvang & $229,83^{* *}$ & 2,61 \\
Branche & 10,29 & 0,09 \\
Baanzekerheid & $454,19^{* *}$ & 4,16 \\
Werktijdfactor & 85,04 & 0,77 \\
Leiding & $498,14^{* *}$ & 5,04 \\
Niveau-eis & $304,38^{*}$ & 2,56 \\
Combi & $-828,86^{* *}$ & $-6,49$ \\
\hline Gecorrigeerde R kwadraat & 1151,62 & \\
Standaard fout & $14,31^{* *}$ & \\
F waarde & & \\
\hline
\end{tabular}

* significant op $5 \%$ niveau

* * significant op $1 \%$ niveau

Pas afgestudeerde academici die een hoog inkomen willen verwerven kunnen beter niet in middelgrote en kleine organisaties gaan werken. De wijdverbreide mening dat het particuliere bedrijfsleven beter betaalt dan de overheid wordt niet bevestigd door de analyse. Deze conclusie laat onverlet dat het bedrijfsleven wellicht in de secundaire inkomenssfeer meer faciliteiten biedt dan de overheid. Bijvoorbeeld in de vorm van een 'auto van de zaak'.

Wat betreft de kenmerken van de arbeidsovereenkomst blijkt de werktijdfactor niet en de lengte van het dienstverband wel van invloed te zijn op het inkomen. Voor de hoogte van het inkomen, 
gemeten bij een volledige werkweek, maakt het namelijk geen verschil of men in deeltijd werkt of dat men een voltijdfunctie uitoefent. Wel blijkt men in een vaste aanstelling een significant hoger inkomen te verwerven dan in een tijdelijke baan. Het verschil wordt geschat op ruim $f 450$,-- bruto per maand.

Het inkomenseffect van de beide functieniveau-indicatoren blijkt significant te zijn. Zoals mag worden verwacht, heeft het werken in een leidinggevende functie en het uitoefenen van een functie die qua niveau aansluit bij de gevolgde opleiding een positief effect op het inkomen. Mensen die een leidinggevende functie uitoefenen, verdienen bruto bijna $f$ 500,-- meer per maand dan degenen die niet leidinggevend werken. Academici die een functie uitoefenen waarvoor een wetenschappelijke opleiding is vereist verdienen bruto ruim $f 300,--$ meer per maand dan wetenschappelijk opgeleiden die onder hun niveau werken.

De invloed van de baanmobiliteit blijkt niet significant te zijn. Dit lijkt tegenstrijdig met de in paragraaf 6.5. gevonden samenhang tussen inkomensstijging en mobiliteit. De verklaring voor deze schijnbare tegenstrijdigheid kan zijn dat men via mobiliteit in banen terechtkomt met kenmerken die tot een hogere beloning aanleiding geven.

Tenslotte blijkt dat betaald werken in een vervolgopleiding, doorgaans als assistent in opleiding of als assistent-geneeskundige in opleiding, fors minder wordt betaald. Het verschil bedraagt ruim $f 800$,- bruto per maand. Degenen die werken combineren met verder studeren zullen deze lage betaling wellicht beschouwen als een investering in human capital die later in de beroepscarrière haar vruchten kan afwerpen.

\section{Vereiste opleiding}

Hieronder wordt nader ingegaan op de aansluiting van de uitgeoefende functie op de gevolgde studie. Eerst komt het niveau van de vereiste opleiding aan bod. Vervolgens wordt de vereiste opleidingsrichting besproken.

In de vragenlijst is een vraag opgenomen naar de voor de uitoefening van de functie minimaal vereiste opleiding. Het antwoord op deze vraag geeft een indicatie voor het al dan niet overeenkomen van het functieniveau met het niveau van de genoten opleiding. Wanneer de vereiste opleiding onder het universitaire niveau ligt is er niet alleen sprake van concurrentie tussen universitair opgeleiden en op andere niveaus opgeleiden, maar ook van onderbenutting van capaciteiten. 
Bijna éénvijfde deel van de betaald werkenden oefent een functie uit die onder het academische niveau ligt. Hun capaciteiten worden bijgevolg onderbenut. Een grote meerderheid oefent echter functies uit die voor academici zijn bestemd. Dit geldt met name voor basisartsen, die vrijwel uitsluitend in functies op academisch niveau werkzaam zijn. Hiervan geeft tabel 19 een beeld. Van de drie nader beschouwde groepen gezondheidswetenschappers zijn het vooral de oudstudenten VW $(34 \%)$ en de oud-studenten GVO $(33 \%)$ die een functie onder het academische niveau uitoefenen. Bij afgestudeerden BB bedraagt het percentage dat onder het academische niveau werkt 21.

Met betrekking tot het niveau van de vereiste opleiding is getracht na te gaan welke variabelen van invloed zijn op de kans dat men op of onder het WO-niveau werkzaam is. De hypothese wordt getoetst dat de kans op onderbenutting verschilt per opleidingsrichting en dat deze kans groter is:

- in tijdelijke deeltijdbanen dan in vaste voltijdbanen;

- in de profit-sector dan bij de overheid;

- voor vrouwen dan voor mannen;

- in functies waar werken niet wordt gecombineerd met verder leren;

- naarmate men korter geleden is afgestudeerd.

De achterliggende gedachten bij de selectie van deze variabelen zijn respectievelijk als volgt:

- een tijdelijke baan die bovendien in deeltijd wordt uitgeoefend, wijst in de richting van een weinig stabiel arbeidsmarktsegment;

- bij opleidingsrichtingen met een relatief slechte arbeidsmarktpositie is de kans groter dat men gedwongen is om uit te wijken naar beroepen die onder het opleidingsniveau liggen;

- een particuliere werkgever heeft meer mogelijkheden om een 'overgeschoolde' aan te nemen dan de overheid met haar nauw omschreven selectiecriteria;

- discriminatie op basis van geslacht kan ertoe leiden dat vrouwen eerder dan mannen worden gedwongen om uit te wijken naar functies beneden het behaalde opleidingsniveau;

- de combinatie van 'overscholing' en verder 'on the job' leren ligt niet voor de hand;

- naarmate men langer op de arbeidsmarkt verblijft heeft men ook meer tijd gehad om een qua niveau passende functie te vinden.

Op basis van deze hypothesen zijn de verklarende variabelen gedefinieerd. Als regressoren voor het vereiste opleidingsniveau van de huidige functie is een aantal dummies opgenomen, namelijk voor werken in de profit-sector (branche), mannelijk geslacht (geslacht), het combineren van werken en leren binnen de functie (combi), het uitoefenen van een tijdelijke part-time functie (baanstabiliteit) en de gevolgde opleidingsrichting. Voor de laatstgenoemde variabele zijn zes 
dummies opgenomen, namelijk geneeskunde, rechten, economie, BB, GVO en VW. De laatste 3 betreffen afstudeerrichtingen binnen gezondheidswetenschappen. De andere afstudeerrichtingen binnen gezondheidswetenschappen fungeren als referentiecategorie voor de gevolgde opleidingsrichting. Voor de precieze omschrijving van de dummy-codes wordt verwezen naar bijlage 3. Als laatste is een variabele opgenomen die het verschil aangeeft tussen 1990 (het jaar van de enquête) en het jaar van afstuderen. Deze variabele (cohort) kan de waarden 1,2,3 of 4 aannemen, afhankelijk van het aantal jaren geleden dat men is afgestudeerd.

Het al dan niet sprake zijn van 'onderbenutting' is geoperationaliseerd door een variabele die de opleidingseisen in de huidige functie weergeeft. De endogene variabele heeft de waarde 1 indien een wetenschappelijke opleiding is vereist. $\mathrm{Er}$ is dan geen sprake van onderbenutting. De endogene heeft de waarde 0 indien de opleidingseisen beneden het WO-niveau liggen. $\mathrm{Er}$ is dan sprake van onderbenutting.

Op basis van deze definities en de geformuleerde hypothesen worden de volgende tekens voor de parameters verwacht:

rechten

andere richtingen dan rechten

branche

geslacht

cohort

baanstabiliteit

combi

Met betrekking tot de verwachte tekens voor de opleidingsrichtingen dient te worden opgemerkt dat het aandeel werkloze afgestudeerden alleen bij de studierichting rechten hoger is dan bij de referentiegroep 'overige afstudeerrichtingen binnen gezondheidswetenschappen'.

Aangezien de endogene variabele slechts twee waarden kan aannemen is gekozen voor een probit-model, waarbij de parameters worden geschat met behulp van de Maximum Likelihood methode. De schattingsresultaten van de analyse worden in tabel 18 weergegeven. Uit deze tabel komt naar voren dat de kans op onderbenutting in het particuliere bedrijfsleven significant groter is dan bij de overheid. Verder blijkt dat wanneer academici 'on the job' verder leren, zij dit significant vaker doen in banen waarvoor een academische opleiding is vereist. De kans op onderbenutting is dus -overeenkomstig de gestelde hypothese- groter in banen waar werken niet wordt gecombineerd met leren. 
Het veronderstelde effect van de verschillen tussen de studierichtingen blijft uit. Bij de studierichting rechten, die het hoogste aandeel werkloze afgestudeerden heeft (zie tabel 15 in paragraaf 7.3.2), wordt geen significant negatief effect gevonden. Dit zou betekenen dat de hoogte van de werkloosheid in een bepaalde studierichting een onvoldoende verklaring biedt voor het uitwijken van afgestudeerden in die studierichting naar banen die onder het opleidingsniveau liggen. Dit zou overigens nog nader kunnen worden onderzocht, bijvoorbeeld door de individuele werkloosheidsduur voorafgaande aan de vervulde functie in de analyse te betrekken. Verder kan hier de veronderstelde causaliteitsrichting parten spelen. Het niet langer zoeken naar een geschikte functie, maar accepteren van een baan beneden het eigen niveau, zal immers de werkloosheid direct ontlasten. Het niet vinden van een negatieve invloed van werkloosheid op het vinden van een baan op WO-niveau, samen met de bevinding dat alleen geneeskunde een significant effect heeft, dat bovendien positief is, zou er ook op kunnen duiden dat niet de hoogte van de werkloosheid maar de mate van exclusiviteit van de relatie tussen opleiding en beroep (getuige de zeer lage Gini-Hirschmancoëfficiënt voor geneeskunde in tabel 15) bepalend is voor de kans dat wordt uitgeweken naar banen die onder het opleidingsniveau liggen.

Tabel 18. Schattingsresultaten van de probit-vergelijking met betrekking tot de kans dat een wetenschappelijke opleiding vereist is in de huidige functie

\begin{tabular}{lcc}
\hline Variabele & $\begin{array}{c}\text { Geschatte } \\
\text { parameter }\end{array}$ & t-waarde \\
\hline Constante & $0.62^{*}$ & 2.49 \\
Geneeskunde & $1.22^{* *}$ & 3.60 \\
Economie & 0.20 & 0.50 \\
Rechten & 0.38 & 1.43 \\
BB & 0.23 & 0.81 \\
GVO & -0.22 & -0.72 \\
VW & -0.31 & -1.02 \\
Cohort & 0.02 & 0.27 \\
Geslacht & -0.01 & -0.10 \\
Branche & $-0.41^{* *}$ & -2.73 \\
Combi & $1.28^{* *}$ & 3.05 \\
Baanstabiliteit & 0.31 & 1.58 \\
\hline
\end{tabular}

* Significant op $5 \%$ niveau

* * Significant op $1 \%$ niveau

Uit de resultaten blijkt verder dat ook geen significante invloed op de onderbenutting kon worden vastgesteld van de variabelen cohort, geslacht en baanstabiliteit. 
$-68-$

Een overall-maatstaf voor de 'fit' van de geschatte vergelijking, zoals een R-kwadraat bij regressie, is niet voorhanden bij probit-modellen. Ten einde toch een indruk te geven van de 'fit' van het model is een maatstaf van de voorspelkracht van het model geconstrueerd. Op basis van de geschatte parameters kunnen ex-post voorspellingen worden gemaakt van de individuele waarnemingen. Gegeven de schattingsresultaten leidt dit tot een percentage van $84 \%$ voor de goed voorspelde waarnemingen. Indien een voorspelling gemaakt zou moeten worden, louter op grond van de waargenomen scores van de endogenen, zou gemiddeld al een percentage van $74 \%$ worden gescoord. Dit betekent dat met voorkennis van de regressoren $10 \%$ van de waarnemingen beter voorspeld kunnen worden.

Het antwoord op de vraag naar de voor de uitoefening van de functie vereiste opleiding biedt niet alleen een indicatie voor het niveau van de functie, maar ook voor de mate waarin de functie aansluit op de gevolgde studierichting en daarmee voor de mate waarin afgestudeerden op de arbeidsmarkt concurrentie ondervinden van afgestudeerden in andere opleidingsrichtingen. Hiervan geeft tabel 19 een beeld.

Tabel 19. Voor de huidige functie vereiste opleiding, naar faculteit (in \%)

\begin{tabular}{lccccc}
\hline & \multicolumn{5}{c}{ Afgestudeerden van de } \\
Opleidingsvereiste & FdG & FdGW & FdR & FdEW & Totaal \\
\hline Ten hoogste HBO & 1 & 27 & 21 & 24 & 17 \\
Elke academische opleiding & -- & 4 & 3 & -- & 2 \\
Eigen of een verwante opleiding & 7 & 41 & 11 & 33 & 21 \\
$\begin{array}{l}\text { Eigen academische opleiding ongeacht } \\
\text { specialisatie * }\end{array}$ & -- & 3 & 35 & 5 & 11 \\
$\begin{array}{l}\text { Uitsluitend de eigen academische opleiding * } \\
\text { Eigen academische opleiding met eigen }\end{array}$ & 92 & -- & -- & -- & 30 \\
specialisatie* & -- & 25 & 30 & 38 & 19 \\
Totaal $n(=100 \%)$ & 251 & 274 & 220 & 21 & 766 \\
\hline
\end{tabular}

* Alleen aan basisartsen voorgelegd.

* Alleen aan gezondheidswetenschappers, juristen en economen voorgelegd.

Zoals eerder is opgemerkt, oefenen de meeste betaald werkende afgestudeerden van de RL (83\%) functies uit die inderdaad voor academici zijn bestemd. Bijna een kwart werkt echter in functies die weliswaar qua niveau aansluiten bij de gevolgde studie maar niet qua richting. Zij werken namelijk in functies die ook door in andere studierichtingen opgeleide academici kunnen 
$-69-$

worden vervuld. Dit is vooral bij gezondheidswetenschappers en economen het geval. Meer dan de helft $(60 \%)$ van de academici werkt echter in functies die op het niveau van studierichtingen aansluiten bij de gevolgde opleiding. Circa ééntiende werkt in functies waarvoor wel de gevolgde studierichting is vereist maar niet de gekozen afstudeerrichting. Dit is met name bij juristen het geval.

Met betrekking tot de vereiste opleidingsrichting kan de mate waarin de studie en het werk op elkaar aansluiten bij de verschillende studierichtingen als volgt worden getypeerd. Basisartsen werken vrijwel allen in exclusief aansluitende functies waarvoor uitsluitend een opleiding in de geneeskunde toegang verschaft. Gezondheidswetenschappers en economen werken relatief vaak in functies waarvoor hun studierichting niet specifiek is vereist. Juristen werken vooral in functies waarvoor een rechtenopleiding specifiek is vereist. Resumerend wijken basisartsen het minst vaak uit naar niet-aansluitende functies. Economen en gezondheidswetenschappers doen dit het meest vaak en juristen nemen hierbij een tussenpositie in.

Hierboven werd opgemerkt dat zowel economen als gezondheidswetenschappers vaak in functies werken die ook door in andere studierichtingen opgeleiden academici kunnen worden vervuld. Wordt binnen de studierichting gezondheidswetenschappen gekeken naar de positie van de economisch gerichte variant $\mathrm{BB}$, dan blijkt inderdaad dat de afgestudeerden van deze variant relatief vaak werken in functies die ook door in andere studierichtingen opgeleide academici kunnen worden vervuld. Het zijn dan ook vooral de afgestudeerden VW $(31 \%)$ en de oud-studenten GVO (32\%) die een functie uitoefenen waarvoor hun specifieke afstudeerrichting is vereist. Bij afgestudeerden in BB bedraagt het percentage slechts 18 .

Uit de enquêteresultaten blijkt tenslotte dat vrouwen meer concurrentie op de arbeidsmarkt ondervinden dan mannen. Vrouwen werken weliswaar niet significant vaker dan mannen beneden hun niveau (zie tabel 18), maar oefenen wel vaker (26\%) dan mannen (20\%) functies uit waarvoor de gevolgde studierichting niet specifiek is vereist.

\subsection{Later gevolgd onderwijs}

Aan de respondenten is gevraagd of zij na het behalen van het doctoraal/basisartsexamen nog verder onderwijs volgen of hebben gevolgd. Indien men meerdere opleidingen of cursussen volgt of heeft gevolgd werd men verzocht om het niveau, de richting en de naam aan te geven van de opleiding of cursus met het grootste aantal lesuren. Tabel 17 in bijlage 1 geeft een beeld van het niveau van de opleidingen die door de respondenten na het afstuderen worden of zijn gevolgd. 
De meeste oud-studenten volgen verder onderwijs na te zijn afgestudeerd. Het betreft hoofdzakelijk opleidingen die onder de noemer post initieel hoger onderwijs (PIHO) vallen. Bij de meeste PIHO-opleidingen gaat het om een vervolg op de eerste fase opleiding, namelijk tweede fase opleidingen en post doctorale beroepsopleidingen. De andere opleidingen worden gevolgd als aanvulling op het aan de RL gevolgde eerste fase curriculum. Deze aanvullende opleidingen zijn vrij gelijk verdeeld over post academisch niveau, eerste fase niveau en HBO- of lager niveau. In cijfers uitgedrukt volgt $32 \%$ van de oud-studenten geen verder onderwijs, $27 \%$ een vervolgopleiding en $36 \%$ een aanvullende opleiding.

Met betrekking tot het later volgen van onderwijs doen zich duidelijke verschillen voor tussen de oud-studenten van de vier faculteiten. Basisartsen en vooral economen volgen vaak vervolgonderwijs, dit wil zeggen tweede fase opleidingen of post doctorale beroepsopleidingen. Gezondheidswetenschappers en juristen volgen vaak aanvullend onderwijs. Het niveau van de aanvullende opleidingen ligt bij juristen iets hoger dan bij gezondheidswetenschappers. Juristen volgen ook vaker post doctorale beroepsopleidingen. Mannen en vrouwen verschillen nauwelijks met betrekking tot het later volgen van onderwijs.

Oud-studenten gaan na afstuderen doorgaans onderwijs volgen dat wat de richting betreft aansluit op het aan de RL gevolgde curriculum. Hiervan geeft tabel 18 in bijlage 1 een beeld.

$\mathrm{Er}$ is nagegaan of het later volgen van onderwijs varieert naar gelang de voor de huidige functie vereiste opleiding. Hiervan geeft tabel 20 een beeld, waarbij de volgende kanttekeningen dienen te worden gemaakt. Men kan eerst een opleiding hebben afgerond en daarna in de huidige functie zijn gestart. Het is echter ook mogelijk dat men aan een opleiding is begonnen nadat men in de huidige functie is gestart. De vraagstelling laat niet toe hiervoor te corrigeren.

Tabel 20. Voor de huidige functie vereiste opleiding en na afstuderen gevolgd onderwijs (in \%)

Vereiste opleiding
Later gevolgd onderwijs $\quad$ HBO of lager Ook andere WO-richtingen Alleen de gevolgde richting

$\begin{array}{lrrr}\text { Geen later onderwijs } & 40 & 31 & 29 \\ \text { Vervolgopleiding } & 15 & 28 & 39 \\ \text { Aanvullend onderwijs } & 45 & 40 & 33 \\ & & & 455\end{array}$

Uit tabel 20 komt naar voren dat academici die een functie beneden hun niveau uitoefenen 
minder vaak later onderwijs volgen of hebben gevolgd dan academici die wel in een functie op hun niveau werkzaam zijn. Dit bevestigt de eerder gemaakte constatering dat onderbenutting van capaciteiten vaker voorkomt in banen waar werken niet wordt gecombineerd met verder leren. Bij de analyse van de potentiële baanmobiliteit in paragraaf 8.4 blijkt bovendien dat academici die onder hun niveau werken vaker op zoek zijn naar een andere baan dan academici die wel in een functie op hun niveau werken. Het lijkt er op dat degenen die onder hun niveau werken minder vaak aanvullend onderwijs of een vervolgopleiding volgen, aangezien zij toch op zoek zijn naar een andere baan. Een en ander lijkt er op te duiden dat men na afstuderen verder onderwijs volgt om de functie die men uitoefent beter te kunnen vervullen. Dit zou een verklaring kunnen vormen voor de bevinding uit tabel 20 dat (de noodzaak voor) het volgen van aanvullend onderwijs afneemt naarmate de functie beter aansluit bij de gevolgde studie.

\subsection{Samenvatting}

In dit hoofdstuk zijn de betaalde functies die men op het moment van enquêteren vervult, getypeerd aan de hand van de werkorganisaties waarin men terecht is gekomen, het beroep dat men uitoefent, het functieniveau en de aansluiting met de genoten opleiding. Ook is ingegaan op het eventueel gevolgde onderwijs na het afstuderen.

\section{Werkorganisaties}

De meeste afgestudeerden zijn voor een baan aangewezen op grote bedrijven/instellingen. Dit geldt met name voor economen. Basisartsen en juristen werken iets vaker dan anderen ook in kleine organisaties.

Ruim de helft van de afgestudeerden komt terecht op de Limburgse arbeidsmarkt. Van alle oudstudenten komen juristen nog het meest terecht op de Limburgse arbeidsmarkt, gezondheidswetenschappers en economen op de landelijke arbeidsmarkt en basisartsen in het buitenland. Limburgse afgestudeerden zijn per studierichting niet mér werkzaam binnen de provincie dan niet-Limburgse afgestudeerden.

De afgestudeerde basisartsen en gezondheidswetenschappers zijn voor een baan vrijwel uitsluitend aangewezen op de niet-zakelijke dienstverlening, met name gezondheidsdiensten. De belangrijkste bron van werkgelegenheid voor de onderzochte economen bestaat uit de zakelijke dienstverlening, met name accountantsbureaus. Juristen nemen een tussenpositie in. Zij zijn in vrijwel gelijke mate aangewezen op de niet-zakelijke dienstverlening (met name openbaar bestuur en universiteiten) als op de zakelijke dienstverlening (met name rechtskundige diensten). 
De analyse van de bedrijfsgroepenspreiding laat zien dat afgestudeerden van de vier studierichtingen van deze universiteit veel uitwijkmogelijkheden naar andere bedrijfsgroepen hebben. De werkgelegenheid(sontwikkeling) van deze studierichtingen hangt bijgevolg niet af van het wel en wee van enkele bedrijfsgroepen. De verschillen in branchegevoeligheid tussen de studierichtingen zijn overigens gering.

\section{Beroep}

De meeste oud-studenten oefenen een wetenschappelijke of andere vakspecialistische functie uit. Basisartsen werken vrijwel uitsluitend in dit soort functies. Gezondheidswetenschappers komen daarnaast in met name beleidvoerende functies terecht. Juristen en vooral economen oefenen ook administratieve functies uit.

Uit de analyse van de beroepsgroepenspreiding komt naar voren dat basisartsen over een relatief klein aantal beroepen zijn verspreid. In de opleidingsrichtingen BB en VW treedt daarentegen een grote beroepenspreiding op. Economie, Nederlands recht en GVO nemen hierbij een tussenpositie in. De lage beroepenspreiding en het lage percentage werkloze basisartsen wijst op voldoende vraag naar afgestudeerden van de studierichting geneeskunde in hun 'eigen' beroependomein. Basisartsen hoeven derhalve niet zo vaak uit te wijken naar andere beroepen. De grote beroepenspreiding in combinatie met het lage percentage werklozen van de opleidingsrichtingen BB en VW wijst op veel uitwijkmogelijkheden zowel binnen als buiten het 'eigen' domein, waardoor de werkloosheidsgevoeligheid van de betreffende opleidingsrichtingen laag is. Ondanks de verspreiding over vrij veel beroepen binnen het 'eigen' beroependomein, is de werkloosheid onder de onderzochte juristen het hoogste. Mogelijk slagen zij er in onvoldoende mate in om buiten het 'eigen' beroependomein werk te vinden.

\section{Functie-niveau}

De meeste respondenten oefenen nog geen leidinggevende functie uit. Basisartsen zijn wel al vaak leidinggevend werkzaam. Naarmate men langer geleden is afgestudeerd neemt de kans toe dat men een leidinggevende functie heeft verworven. Mannen zijn vaker dan vrouwen in leidinggevende functies werkzaam.

Naast het al dan niet leidinggeven vormt ook het inkomen een indicator voor het niveau van de functie. In de uitgevoerde regressie-analyse komt naar voren dat de hoogte van het bruto maandinkomen bij een volledige werkweek hoger is wanneer men geneeskunde of BB heeft gestudeerd, meer jaren arbeidsmarktervaring heeft, wanneer men man is, in een grote arbeidsor- 
ganisatie werkt, een vaste aanstelling heeft, wanneer men werkt in een functie op academisch niveau, een leidinggevende functie uitoefent en wanneer men niet werken en leren binnen de functie combineert.

Bij éénvijfde deel van de betaald werkende oud-studenten is sprake van 'onderbenutting' doordat zij een functie uitoefenen waarvoor een opleiding op academisch niveau niet is vereist. De kans op onderbenutting is in het particuliere bedrijfsleven groter dan bij de overheid met haar nauw omschreven selectiecriteria. Deze kans is ook groter in banen waar werken niet wordt gecombineerd met verder leren. Daarentegen lopen basisartsen een kleinere kans om onder hun niveau terecht te komen. Zij wijken ook het minst vaak uit naar niet bij hun studierichting aansluitende functies. Economen en gezondheidswetenschappers doen dit het meest vaak en juristen nemen hierbij een tussenpositie in.

\section{Later onderwijs}

De meeste oud-studenten volgen verder onderwijs na te zijn afgestudeerd. Het betreft voornamelijk opleidingen die onder de noemer post initieel hoger onderwijs vallen. Bij de meeste van deze opleidingen gaat het om een direct vervolg op de eerste-fase, namelijk tweede-fase opleidingen en andere post doctorale opleidingen. De overige opleidingen worden slechts gevolgd als aanvulling op de aan de RL gevolgde eerste-fase opleiding. Naarmate de functie beter aansluit bij de gevolgde studierichting neemt het volgen van vervolgonderwijs toe en (de noodzaak voor) het volgen van aanvullende opleidingen af. 


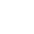




\section{HUIDIGE ARBEIDSSITUATIE}

\subsection{Inleiding}

In hoofdstuk 5 is een beeld geschetst van de verschuivingen in de participatie aan het arbeidsproces tijdens het eerste jaar na de intrede op de arbeidsmarkt. In dit hoofdstuk komt de huidige participatie aan bod. Eerst wordt ingegaan op de arbeidssituatie die men op het moment van enquêteren inneemt. Met nadruk wordt er op gewezen dat het hierbij gaat om de arbeidssituatie die volgens de respondenten hun dagelijkse situatie het beste weergeeft. Aansluitend op de bespreking van de arbeidssituatie wordt nagegaan hoeveel oud-studenten werkloos zijn overeenkomstig de definitie van het CBS en hoeveel overeenkomstig de definitie van het Ministerie van Sociale Zaken en Werkgelegenheid (SZW). Vervolgens wordt de stabiliteit besproken van de baan die men thans heeft. Tenslotte wordt de kans geschat dat men van baan gaat veranderen.

\subsection{Participatie aan het arbeidsproces}

In paragraaf 5.2 is ingegaan op de verschuivingen in de arbeidssituatie die zich in de loop van het eerste jaar na afstuderen hebben voorgedaan. In deze paragraaf wordt ingegaan op de huidige arbeidssituatie, dit wil zeggen de arbeidssituatie die door de respondenten naar eigen zeggen wordt ingenomen in de maand waarin men de vragenlijst heeft ingevuld. Gevraagd is naar de situatie welke het beste past bij de dagelijkse bezigheden op het moment van enquêteren. De respondenten konden hierbij kiezen uit de volgende mogelijkheden:

- betaald werk (inclusief in combinatie met opleiding);

- militaire dienstplicht (inclusief vervangende dienstplicht);

- full-time onderwijs;

- huishouden verzorgend;

- arbeidsongeschikt, geheel of gedeeltelijk;

- onbetaald werk met behoud van uitkering;

- werkloos, zonder onbetaald werk;

- andere situatie.

De resultaten zijn vermeld in tabel 21 . Hieruit komt naar voren dat $82 \%$ van de oud-studenten momenteel een betaalde functie uitoefent. Met betrekking tot het al dan hebben van een betaalde baan zijn de verschillen tussen de studierichtingen significant, waarbij juristen beduidend minder vaak dan basisartsen, gezondheidswetenschappers en economen betaald werk verrichten. 
Tabel 21. Huidige arbeidssituatie, naar faculteit (in \%)

\begin{tabular}{lrrrrr}
\hline & \multicolumn{5}{c}{ Afgestudeerden van de } \\
& FdG & FdGW & FdR & FdEW & Totaal \\
\hline & & & & & \\
Betaald werk (incl. in combinatie met opleiding) & 89 & 83 & 71 & 93 & 82 \\
In militaire dienst & 5 & 2 & 3 & 2 & 3 \\
Studerend & 0 & 6 & 10 & -- & 5 \\
Huishouden verzorgend & 0 & 2 & 1 & -- & 1 \\
Onbetaald werk met behoud van uitkering & 0 & 3 & 3 & -- & 2 \\
Werkloos, zonder onbetaald werk & 4 & 4 & 10 & 5 & 1 \\
Andere situatie & 1 & 1 & 2 & -- & 1100 \\
Totaal $n$ (=100\%) & 330 & 385 & 343 & 42 & \\
\hline
\end{tabular}

Binnen de studierichting gezondheidswetenschappen doen zich significante verschillen voor tussen de drie nader beschouwde afstudeerrichtingen. Oud-studenten BB hebben vaker betaald werk $(91 \%)$ dan oud-studenten VW $(82 \%)$ en oud-studenten GVO $(78 \%)$. Er is ook nagegaan of mannen en vrouwen significant verschillen met betrekking tot het al dan niet verrichten van betaald werk. Dit blijkt niet het geval te zijn.

In paragraaf 1.1.1. is er reeds op gewezen dat een inventarisatie door het ROA van verricht 'follow-up' onderzoek onder afgestudeerden van Nederlandse universiteiten heeft aangetoond dat vergelijkbare gegevens over afgestudeerden van andere universiteiten (met uitzondering van de LUW) vooralsnog helaas ontbreken.

\section{Kans op betaald werk}

Met behulp van een probit-model is de kans geschat dat men thans een betaalde baan heeft. De schattingsresultaten worden in tabel 22 weergegeven. Bij de operationalisatie van de variabele 'huidige arbeidssituatie' is een binaire endogene geconstrueerd, die de waarde 0 heeft indien de respondent geen betaalde baan heeft en 1 indien dit wel het geval is. Als verklarende variabelen voor de huidige arbeidssituatie zijn twee persoonskenmerken en vier achtergrondkenmerken in de schattingsvergelijking opgenomen. De persoonskenmerken betreffen het geslacht en de leeftijd. De achtergrondkenmerken betreffen arbeidsmarktrelevante ervaring vóor afstuderen (betaalde werkervaring en bestuurlijke ervaring), de gevolgde opleidingsrichting en het aantal jaren dat men reeds is afgestudeerd. 
Er wordt verondersteld dat de kans om een betaalde baan te verwerven per opleidingsrichting verschilt. Verder wordt verwacht dat vrouwen een kleinere kans dan mannen hebben om betaald werkzaam te zijn; dit als gevolg van eventuele discriminatie van vrouwen op de arbeidsmarkt of omdat vrouwen zich in mindere mate dan mannen op de arbeidsmarkt aanbieden. Jongeren hebben een grotere kans op een betaalde baan dan ouderen omdat het voor een werkgever aantrekkelijker is om een jongere in dienst te nemen. Immers, eventuele investeringen in bedrijfsspecifieke opleidingen kunnen bij jongeren over een groter aantal arbeidsjaren worden terugverdiend dan bij ouderen het geval is. Extra kwalificaties in de vorm van betaalde werkervaring of bestuurlijke ervaring, opgedaan vóór afstuderen, maken iemand voor een werkgever aantrekkelijker en vergroten bijgevolg de kans om een betaalde baan te verwerven. Deze kans is ook groter naarmate men meer tijd heeft gehad om een baan te zoeken.

Een aantal regressoren voor de kans op betaald werk is gedefinieerd als dummy-variabelen, namelijk mannelijk geslacht (geslacht), het beschikken over betaalde werkervaring vóor afstuderen (werk 1), vóór afstuderen opgedane bestuurlijke ervaring (bestuur) en opleidingsrichting (geneeskunde, rechten, economie, BB, GVO en VW). De andere afstudeerrichtingen binnen gezondheidswetenschappen dan $B B, G V O$ en $V W$ fungeren als referentiecategorie voor de gevolgde opleidingsrichting. De leeftijd op het moment van bevraging is gedefinieerd in jaren. Het verschil tussen het jaar waarin de enquête plaatsvond en het jaar van afstuderen (de variabele 'cohort') kan de waarden 1,2,3 en 4 aannemen, afhankelijk van het aantal jaren geleden dat men is afgestudeerd.

Op basis van de hiervoor genoemde veronderstellingen en de wijze waarop de variabelen zijn geoperationaliseerd, worden positieve parameter-tekens verwacht voor geslacht, betaalde werkervaring opgedaan vóór afstuderen (werk 1), bestuurlijke ervaring opgedaan vóór afstuderen (bestuur) en het aantal jaren geleden dat men is afgestudeerd (cohort). Voor de leeftijd wordt een negatief teken verwacht.

Uit de schattingsresultaten blijkt dat de kans op een betaalde baan significant wordt beïnvloed door de reeds vóor afstuderen opgedane betaalde werkervaring, de gevolgde studierichting en de tijd die men heeft gehad om werk te zoeken. De multivariate analyse bevestigt het beeld dat reeds in kruistabel 20 bij de gevolgde studierichting naar voren kwam, namelijk dat juristen het minder goed doen op de arbeidsmarkt en economen een grotere kans hebben om betaald werk te vinden. Het beschikken over extra kwalificaties in de vorm van betaalde werkervaring vóór afstuderen vergroot de kans op een baan. Deze kans neemt ook toe naarmate men meer tijd heeft gehad om werk te zoeken. Het geslacht en de leeftijd zijn niet van invloed op de kans om 
betaald werk te verwerven. Ook de invloed van bestuurlijke ervaring, opgedaan vóór afstuderen, is niet significant.

Tabel 22. Schattingsresultaten van de probit-vergelijking met betrekking tot de kans op betaald werk

\begin{tabular}{lcc}
\hline Variabele & $\begin{array}{c}\text { Geschatte } \\
\text { parameter }\end{array}$ & t-waarde \\
\hline Constante & 0.46 & 1.69 \\
Geneeskunde & 0.25 & 1.35 \\
BB & 0.25 & 1.13 \\
GVO & -0.43 & -1.93 \\
VW & -0.29 & -1.22 \\
Rechten & $-0.42^{*}$ & -2.41 \\
Economie & $0.75^{*}$ & 2.15 \\
& & -1.91 \\
Geslacht & -0.19 & -0.90 \\
Leeftijd & -0.01 & 2.87 \\
Werk 1 & $0.29^{* *}$ & -0.61 \\
Bestuur & -0.06 & 6.81 \\
Cohort & $0.37^{* *}$ & \\
\hline
\end{tabular}

* Significant op $5 \%$ niveau

* * Significant op $1 \%$ niveau

\section{Werklozen volgens CBS-definitie}

Uit tabel 21 komt naar voren dat $8 \%$ van de oud-studenten zich als werkloos beschouwt. Het percentage werklozen volgens CBS-definitie ligt echter iets hoger. Volgens deze definitie zijn als werkloos te beschouwen de oud-studenten die geen betaald werk hebben, op zoek zijn naar betaald werk en direct beschikbaar zijn voor de arbeidsmarkt. Het volgens deze definitie berekende werkloosheidspercentage onder afgestudeerden bedraagt in totaal $10 \%$, onder basisartsen $4 \%$ onder gezondheidswetenschappers $8 \%$, en onder economen $5 \%$. Het werkloosheidspercentage onder juristen is met $18 \%$ significant hoger dan onder de afgestudeerden van de andere faculteiten. Tot de juristen die zich beschouwen als full-time student behoort een aantal verborgen werklozen dat op zoek is naar betaald werk en direct beschikbaar is voor de arbeidsmarkt. Zij vallen bijgevolg onder de CBS-definitie van werkloosheid. Dit verklaart het grote verschil tussen de werkloosheid, gemeten volgens CBS-definitie, en de werkloosheid volgens eigen opgave van de juristen.

Van de nader beschouwde gezondheidswetenschappers is het percentage werklozen volgens CBS-definitie onder oud-studenten GVO met $9 \%$ hoger, dan onder oud-studenten VW en oudstudenten BB met elk $5 \%$. Het aandeel van werklozen, gemeten volgens de definitie van het 
CBS, bedraagt bij zowel mannen als vrouwen $10 \%$.

\section{Werklozen volgens SZW-definitie}

Van de oud-studenten die geen betaald werk hebben is een aantal op zoek naar betaald werk, bij een arbeidsbureau ingeschreven en direct beschikbaar voor de arbeidsmarkt. Aldus gedefinieerd (SZW-definitie) bedraagt het percentage werklozen in de totale populatie $7 \%$. Volgens de SZW-definitie bestaat 3\% van de basisartsen uit werklozen, $6 \%$ van de gezondheidswetenschappers en $5 \%$ van de economen. Het percentage werklozen onder juristen is met $11 \%$ significant hoger dan onder de afgestudeerden van de andere faculteiten.

Van de nader beschouwde gezondheidswetenschappers is het percentage werklozen volgens SZW-definitie onder oud-studenten GVO met $7 \%$ hoger, hoewel niet significant, dan onder oudstudenten VW $(5 \%)$ en oud-studenten BB $(4 \%)$. Het aandeel van werklozen, gemeten volgens de definitie van SZW, bedraagt bij mannen $6 \%$ en bij vrouwen $7 \%$.

Ook uit de landelijke cijfers die zijn opgenomen in de bijlage met cijfers en feiten van het Ontwerp Hoger Onderwijs en Onderzoekplan (HOOP) ${ }^{24}$ komt naar voren dat het aandeel van werklozen bij economie en geneeskunde lager is dan bij rechten. De cijfers met betrekking tot gezondheidswetenschappen kunnen niet aan het HOOP worden ontleend, aangezien in de bijlage van dit plan onder het deelgebied 'gezondheid' naast geneeskunde, tandheelkunde en diergeneeskunde een rubriek 'overige medische wetenschappen' is opgenomen, die is opgebouwd uit 'sociale gezondheidszorg' en 'overige medische wetenschappen'. Overigens gaan de in het HOOP opgenomen werkloosheidscijfers behept met een aantal manco's. In de eerste plaats zijn de gegevens over werkloze WO-opgeleiden afkomstig van de regionale arbeidsbureaus. Deze gegevens zijn onvolledig omdat hierin niet begrepen zijn de werklozen die zich niet bij een arbeidsbureau hebben laten inschrijven. Bovendien zijn de cijfers vervuild, aangezien degenen die inmiddels werk hebben gevonden, maar zich nog niet hebben laten uitschrijven, wel worden meegenomen. Ook personen die wel werk hebben en via inschrijving bij een arbeidsbureau ander werk zoeken, kunnen in de cijfers zijn meegerekend. In de tweede plaats worden de aantallen aldus geregistreerde 'werklozen' niet uitgedrukt als percentage van het werkelijke aantal tot de beroepsbevolking behorende WO-opgeleiden, maar als percentage van het via de zogenaamde 'reconstructiemethode' geraamde aantal tot de beroepsbevolking behorende WO-opgeleiden, waarbij academici met dubbele doctoraaldiploma's dubbel worden

24. Ministerie van Onderwijs en Wetenschappen (1991). 
geteld $^{25}$. Gezien deze onvolkomenheden wordt afgezien van het vergelijken van de hoogte van het aandeel werkloze afgestudeerden van de RL met de in het HOOP gepresenteerde landelijke aandelen van werkloze academici. Het vergelijken van de hoogte van aandelen werklozen heeft ook weinig zin omdat het in dit onderzoek gaat om recent afgestudeerden en in de HOOP-cijfers ook om academici die al langer geleden zijn afgestudeerd.

\subsection{Zekerheid van de huidige baan en werktijdfactor}

In hoofdstuk 7 is een aantal kenmerken aan bod gekomen van het werk dat wordt verricht door degenen die thans een betaalde baan hebben. In deze paragraaf wordt eerst nader ingegaan op een aspect van de arbeidsovereenkomst met een werkgever dat indicatief is voor de stabiliteit van de baan. Dit aspect is het vaste of tijdelijke karakter van de arbeidsovereenkomst (baanzekerheid). Een stabiele baan kan worden getypeerd door een aanstelling voor onbepaalde tijd. Een tijdelijke aanstelling wijst daarentegen op een instabiele baan. Vervolgens komt de lengte van de werkweek aan bod.

\section{Baanzekerheid}

Bijna alle academici zijn in loondienst werkzaam. Slechts $5 \%$ werkt als zelfstandige voor eigen rekening of risico, dus in een eigen bedrijf of praktijk. Werken voor eigen rekening of risico komt bij juristen $(8 \%)$ en basisartsen $(7 \%)$ iets vaker voor dan bij economen $(3 \%)$ en gezondheidswetenschappers (1\%). Mannen (7\%) zijn vaker dan vrouwen (3\%) als zelfstandige werkzaam.

Bij degenen die in loondienst werken kan worden nagegaan hoe zeker hun baan is. De variabele baanzekerheid verwijst naar het aantal maanden waarop de formele aanstelling in loondienst betrekking heeft. Hiervan geeft tabel 19 in bijlage 1 een beeld. Een aanstelling voor meer dan vijf jaar wordt hierbij geacht een vast dienstverband te zijn.

Uit tabel 19 in bijlage $1 \mathrm{komt}$ naar voren dat de meeste afgestudeerden een tijdelijke aanstelling hebben. Aanstellingen voor maximaal 12 maanden komen het meest frequent voor. Met name basisartsen werken relatief vaak in korte aanstellingen (maximaal 2 jaar) en relatief weinig in vaste dienst. Dit kan verband houden met het gegeven dat een aantal basisartsen betaald werkt in een (tijdelijke) opleidingsplaats tot medisch specialist, of in afwachting van een dergelijke opleidingsplaats tijdelijk ander werk accepteert. Van alle afgestudeerden zijn vooral de 
$-80-$

economen er in geslaagd om een vaste aanstelling te verwerven. Binnen de studie gezondheidswetenschappen zijn vooral de afgestudeerden in de economisch gerichte variant BB er vaak in geslaagd om een vaste baan te vinden ( $33 \%$ vast dienstverband). Bij oud-studenten VW en oud-studenten GVO bedragen de percentages respectievelijk 26 en 13.

Wat de baanzekerheid betreft zijn er geen significante verschillen tussen mannen en vrouwen.

Bij de populatie die thans betaald werk heeft, is onderzocht in hoeverre de gevolgde opleidingsrichting van invloed is geweest op het al dan niet verwerven van een vaste baan. De endogene variabele 'baanzekerheid' heeft de waarde 0 indien men thans een aanstelling in tijdelijke dienst heeft en de waarde 1 bij een vaste baan (aanstelling voor onbepaalde tijd). Aangezien de endogene variabele binair is, zijn de parameters geschat met behulp van een probit-model. Tabel 23 geeft de schattingsresultaten weer.

Tabel 23. Schattingsresultaten van de probit-vergelijking met betrekking tot de kans op een vaste baan

\begin{tabular}{lcc}
\hline Variabele & $\begin{array}{c}\text { Geschatte } \\
\text { parameter }\end{array}$ & t-waarde \\
\hline Constante & $-1.16^{* *}$ & -3.41 \\
Geneeskunde & -0.35 & -1.67 \\
BB & $0.44^{*}$ & 1.98 \\
GVO & -0.29 & -1.04 \\
VW & 0.34 & 1.33 \\
Rechten & 0.22 & 1.08 \\
Economie & $1.06^{* *}$ & 3.78 \\
& & \\
Geslacht & 0.14 & 1.27 \\
Leeftijd & 0.01 & 0.73 \\
Werk 1 & -0.20 & -1.85 \\
Bestuur & 0.06 & 0.59 \\
Cohort & 0.03 & 0.62 \\
\hline
\end{tabular}

* Significant op $5 \%$ niveau

* : Significant op $1 \%$ niveau

In de analyse zijn dezelfde verklarende variabelen opgenomen die ook zijn gebruikt bij het schatten van de kans op betaald werk, namelijk de opleidingsrichting, de twee persoonskenmerken geslacht en leeftijd, de twee vormen van arbeidsmarktrelevante ervaring vóor afstuderen (betaalde werkervaring en bestuurlijke ervaring), alsmede het aantal jaren dat men reeds is afgestudeerd. $\mathrm{Er}$ wordt verondersteld dat de verklarende variabelen een overeenkomstige invloed zullen hebben op de kans om een vaste baan te verwerven als reeds in paragraaf 8.2 is beschreven bij de analyse van de kans om betaald werk te vinden. Dit wil 
zeggen dat positieve parameter-tekens worden verwacht met betrekking tot geslacht, betaalde werkervaring opgedaan vóór afstuderen (werk 1), bestuurlijke ervaring opgedaan vóór afstuderen (bestuur) en het aantal jaren geleden dat men is afgestudeerd (cohort). Voor de leeftijd wordt ook bij deze analyse een negatief teken verwacht.

De reeds in de bivariate analyse geconstateerde verschillen tussen studie/afstudeerrichtingen worden door de multivariate analyse bevestigd. Uit de analyseresultaten komt naar voren dat economen niet alleen een grotere kans hebben om betaald werk te vinden maar ook een grotere kans op een vaste baan hebben. Afgestudeerden van de economisch gerichte variant binnen gezondheidswetenschappen BB hebben weliswaar geen grotere kans op een betaalde baan, maar als ze betaald werk krijgen hebben zij wel een significant grotere kans op een vaste baan. Juristen hebben weliswaar een kleinere kans om een betaalde baan te verwerven, maar hun kans op een vaste baan is niet kleiner als zij betaald werk vinden.

De reeds vóor afstuderen opgedane werkervaring, alsmede de tijd die men heeft gehad om werk te zoeken, vergroten weliswaar de kans op betaald werk maar zijn niet van invloed op de kans om een vast dienstverband te krijgen.

De twee persoonskenmerken in de analyse, leeftijd en geslacht, zijn noch van invloed op de kans om betaald werk te krijgen noch van invloed op de kans om een aanstelling voor onbepaalde tijd te verwerven. Hetzelfde geldt voor de invloed van bestuurlijke ervaring die men vò̀r afstuderen heeft opgedaan.

\section{Werktijdfactor}

Naast het vaste of tijdelijke karakter is de lengte van de werkweek een aspect van de aanstelling dat indicatief kan zijn voor de stabiliteit van de baan. Tabel 20 in bijlage 1 geeft een overzicht van het gemiddelde aantal arbeidsuren per week in de huidige functie.

Bijna éénvijfde deel van de afgestudeerden werkt in deeltijd (minder dan 35 uur per week). De rest heeft een volledige baan, waarin de meesten veertig uur per week werken. Basisartsen draaien de meeste uren per week. Gezondheidswetenschappers komen meer dan anderen in deeltijdfuncties terecht. Het gemiddelde aantal arbeidsuren per week is bij hen dan ook het laagst. Het grote aandeel van vrouwen bij gezondheidswetenschappers kan hiervoor de verklaring vormen. Vrouwen werken over het geheel genomen gemiddeld korter dan mannen. Dit is bij iedere faculteit het geval. Van de werkende mannen heeft $12 \%$ een deeltijdbaan. Bij de werkende vrouwen is het percentage twee keer zo hoog (25\%). 
Binnen de groep gezondheidswetenschappers werken de afgestudeerden in de economisch gerichte variant BB minder vaak in deeltijd (slechts $18 \%$ werkt in een part-time functie) dan oud-studenten VW $(37 \%)$ en oud-studenten GVO $(35 \%)$.

\section{Baanstabiliteit}

De combinatie van baanzekerheid én werktijdfactor kan indicaties verschaffen over de stabiliteit van de baan. Hierbij kunnen als uitersten worden onderscheiden, aan de ene kant tijdelijke parttime banen en aan de andere kant vaste full-time banen. De verdeling naar baanstabiliteit is als volgt:

tijdelijk, part-time werk $18 \%$ tijdelijk, full-time werk $61 \%$ vast, part-time werk $\quad 3 \%$ vast, full-time werk $18 \%$ (hiertoe behoren onder meer de AIO's, OIO's en AGIO's)

$$
100 \% \quad(n=910)
$$

\subsection{Potentiële baanmobiliteit}

In paragraaf $8.2 \mathrm{kwam}$ naar voren dat de meeste oud-studenten thans een betaalde baan hebben. Onder de betaald werkenden bevindt zich evenwel een aantal oud-studenten met een baan die om welke reden dan ook niet bevalt, aangezien zij op zoek zijn naar een andere baan. In de onderhavige paragraaf wordt eerst de omvang van deze potentiële baanmobiliteit geschetst. Vervolgens wordt ingegaan op kenmerken van de baan die hierbij een rol spelen.

Onder deze populatie van nog recent afgestudeerden is de potentiële baanmobiliteit vrij omvangrijk. Bijna éénderde (29\%) van de betaald werkenden is op zoek naar een andere baan. Er doen zich significante verschillen tussen de studierichtingen voor, waarbij basisartsen het meest vaak een andere baan zoeken ( $40 \%$ van de betaald werkenden) en economen het minst vaak (8\%). Gezondheidswetenschappers en juristen nemen een tussenpositie in met respectievelijk $27 \%$ en $23 \%$. Economen zijn het minst vaak van plan om van baan te veranderen. Hetzelfde kan worden geconstateerd binnen de studie gezondheidswetenschappen. Ook hier zijn de afgestudeerden in de economisch gerichte variant BB minder vaak voornemens om van baan te veranderen ( $20 \%$ is op zoek naar een andere baan) dan oud studenten (VW) $(28 \%)$ en oud-studenten GVO $(29 \%)$.

Met behulp van een probit-model is de kans geschat dat men al dan niet op zoek gaat naar een andere baan. Als verklarende variabelen voor de potentiële baanmobiliteit zijn drie achtergrondkenmerken in de schattingsvergelijking opgenomen en zeven baan-gerelateerde 
kenmerken. De achtergrondkenmerken betreffen het geslacht, de gevolgde opleidingsrichting en het aantal jaren dat men reeds is afgestudeerd. De baangerelateerde kenmerken hebben betrekking op het niveau van de functie (de mate waarin de baan aansluit bij de gevolgde studie, het genoten inkomen en het al dan niet leidinggeven), de stabiliteit van de baan (lengte van de werkweek en duur van de aanstelling), de branche waarbinnen de baan wordt uitgeoefend en het al dan niet combineren van werken en opleiding volgen tijdens de functieuitoefening.

Er wordt verondersteld dat men eerder op zoek zal gaan naar een andere baan wanneer men werkt in een laag functieniveau (laag inkomen, niet-leidinggevende en minder goed aansluitende functie) en een weinig stabiele baan (deeltijdwerk en tijdelijke baan) dan in een hogere functie (hoog inkomen, leidinggevende en goed aansluitende functie) en een stabiele arbeidsovereenkomst (voltijdbaan en aanstelling in vaste dienst). Verder wordt verondersteld dat de kans dat men van baan wil veranderen groter is:

- bij vrouwen, omdat vrouwen als gevolg van kansongelijkheid wel eens gedwongen kunnen zijn om banen te accepteren die niet hun eerste keus zijn en daarom vaker dan mannen op zoek zijn naar een andere baan.

- wanneer men recenter is afgestudeerd, omdat naarmate men langer op de arbeidsmarkt verblijft men ook meer tijd heeft gehad om een baan te vinden die bevalt. Men zal dan minder snel zijn geneigd om een andere baan te zoeken.

- wanneer men bij de overheid werkt, omdat een particuliere werkgever meer mogelijkheden heeft om een baan, in de sfeer van secundaire arbeidsvoorwaarden, aantrekkelijk te maken dan de overheid met haar nauw omschreven arbeidsvoorwaarden. Via dit mechanisme kan van het werken bij de overheid een mobiliteitsbevorderend effect uitgaan.

- wanneer werken niet wordt gecombineerd met 'on the job' leren, omdat pas afgestudeerde academici die 'on the job' leren, gemotiveerd zullen zijn om de opleidingsbaan te voltooien, teneinde hiermee hun toekomstige arbeidsmarktpositie te versterken. Zij zullen bijgevolg niet zo vaak op zoek zijn naar een andere baan zo lang zij de opleiding nog niet hebben afgerond.

Alle variabelen zijn gedefinieerd als dummy-variabelen (zie hiervoor bijlage 3 en de onderbenuttingsanalyse uit paragraaf 7.5.), behoudens het inkomen, de vereiste opleiding en het aantal jaren dat men is afgestudeerd, die als volgt zijn geoperationaliseerd. Het inkomen is geoperationaliseerd door de negen klassen oplopend te nummeren van 1 tot en met 9 . De voor de functie vereiste opleiding is geoperationaliseerd in oplopende mate van aansluiting, waarbij de waarde 1 betekent dat zelfs geen opleiding op WO-niveau is vereist, de waarde 2 dat slechts een opleiding op WO-niveau is vereist en de waarde 3 dat de gevolgde studierichting specifiek is vereist. Het verschil tussen het jaar van de enquête en het jaar van afstuderen (de variabele 
'cohort') kan de waarden 1,2,3 en 4 aannemen, afhankelijk van het aantal jaren geleden dat men is afgestudeerd.

De endogene variabele 'potentiële baanmobiliteit' heeft de waarde 0 indien men niet op zoek is naar een andere baan en de waarde 1 indien men dat wel is. Aangezien de endogene variabele slechts twee waarden kan aannemen is gekozen voor een probit-model, waarbij de parameters worden geschat met behulp van de Maximum Likelihood methode. De schattingsresultaten van de analyse worden in tabel 24 weergegeven.

Op basis van de genoemde veronderstellingen en de wijze waarop de variabelen zijn gedefinieerd, worden voor alle parameters, die niet betrekking hebben op de gevolgde opleidingsrichting, negatieve tekens verwacht. Overigens fungeren de andere afstudeerrichtingen binnen gezondheidswetenschappen dan BB, GVO en VW als referentiecategorie voor de gevolgde opleidingsrichting.

Tabel 24. Schattingsresultaten van de probit-vergelijking met betrekking tot de potentiële baanmobiliteit.

\begin{tabular}{lll}
\hline Variabele & $\begin{array}{l}\text { Geschatte } \\
\text { parameter }\end{array}$ & t-waarde \\
\hline Constante & 0.55 & 1.64 \\
Geneeskunde & & \\
Economie & $0.76^{* *}$ & 2.99 \\
Rechten & & \\
BB & -0.06 & -0.23 \\
GVO & -0.29 & -1.06 \\
VW & -0.16 & -0.55 \\
& -0.28 & -0.93 \\
Cohort & & -0.22 \\
Geslacht & -0.01 & -0.14 \\
Branche & -0.02 & -1.73 \\
Combi & & -5.20 \\
Baanzekerheid & -0.27 & -2.09 \\
Werktijdfactor & $-0.87^{*}$ & -1.63 \\
Leiding & $-0.30^{*}$ & 1.91 \\
Aansluiting & -0.24 & -2.92 \\
Inkomen & 0.23 & -1.64 \\
\hline
\end{tabular}

* Significant op $5 \%$ niveau

* * Significant op $1 \%$ niveau.

Uit de schattingsresultaten blijkt dat werkgevers die academici een tijdelijke aanstelling geven of een functie laten uitoefenen die minder goed aansluit bij de gevolgde opleiding een significant verhoogd risico lopen dat deze medewerkers zullen opstappen. Daarentegen zullen academici 
die 'on the job' een vervolgopleiding doorlopen deze ook willen afmaken, aangezien bij de combinatie van werken en leren de kans dat men op zoek is naar ander werk significant kleiner blijkt te zijn.

Verder blijken basisartsen significant vaker dan andere afgestudeerden op zoek te zijn naar een andere baan. Waarschijnlijk is de achterliggende verklaring voor dit resultaat dat zij een opleidingsplaats voor medisch specialist (waaronder huisarts of sociaal-geneeskundige) zoeken, vanuit een baan die zij in afwachting daarvan hebben geaccepteerd. Tenslotte blijkt uit de schattingsresultaten dat overeenkomstig de gestelde hypothese men significant minder vaak op zoek is naar een andere baan als de aansluiting tussen de gevolgde studie en de vervulde functie beter is. Er kon geen significante invloed op de neiging van baan te veranderen worden vastgesteld van de tijd dat men is afgestudeerd, het geslacht, of men in de profit-sector werkt, de werktijdfactor, of men leiding geeft en de hoogte van het inkomen.

\subsection{Samenvatting}

Ruim $80 \%$ van de oud-studenten heeft op het moment van enquêtering een betaalde baan. Het betreft meestal aanstellingen in tijdelijke dienst. Juristen zijn minder vaak dan anderen betaald werkzaam en volgen na afstuderen vaker full-time onderwijs. Tot de juristen die een voltijd opleiding volgen behoort echter een aantal verborgen werklozen dat op zoek is naar betaald werk en direct beschikbaar is voor de arbeidsmarkt.

Uit de analyse van de kans op werk en de kans op een vaste baan komt naar voren dat economen niet alleen een grotere kans hebben om betaald werk te vinden, maar ook een grotere kans om een vaste aanstelling te krijgen. Afgestudeerden van de economisch gerichte variant binnen gezondheidswetenschappen BB hebben geen grotere kans op een betaalde baan, maar als ze betaald werk krijgen hebben zij wel een significant grotere kans op een vaste baan. Juristen hebben een kleinere kans om een betaalde baan te verwerven, maar de kans dat deze baan vast is, is niet kleiner. De reeds vóór afstuderen opgedane werkervaring alsmede de tijd die men heeft gehad om werk te zoeken vergroten weliswaar de kans op betaald werk, maar zijn niet van invloed op de kans om een vast dienstverband te krijgen.

Ruim $80 \%$ van de thans betaald werkende oud-studenten werkt in voltijd. Basisartsen draaien de langste werkweken. Voor alle studierichtingen geldt overigens dat vrouwen vaker dan mannen in deeltijd werken.

Bijna éénderde van de betaald werkenden is op zoek naar een andere baan. De neiging van baan 
$-86-$

te veranderen is groter wanneer men een tijdelijke baan heeft, onder zijn of haar niveau werkt of wanneer men geneeskunde heeft gestudeerd. In het laatste geval zal men waarschijnlijk op zoek zijn naar een opleidingsplaats voor medisch specialist, waartoe ook huisartsen en sociaalgeneeskundigen worden gerekend. Degenen die 'on the job' een vervolgopleiding doorlopen willen deze ook afmaken. Zij zijn daarom minder vaak op zoek naar een andere baan. 


\section{SAMENVATTING EN CONCLUSIES}

\subsection{Inleiding}

In dit rapport zijn de resultaten gepresenteerd van de eerste toepassing van de arbeidsmarktscanner aan de Rijksuniversiteit Limburg (RL). Met behulp van deze scanner kunnen de arbeidsmarktpositie en loopbanen van de afgestudeerden periodiek in kaart worden gebracht. Een ander belangrijk facet van dit onderzoek heeft betrekking op de aansluiting tussen de aan de RL genoten opleiding en de werkzaamheden die men thans verricht. De systematiek van de arbeidsmarktscanner bestaat hieruit dat oud-studenten circa éen jaar na hun afstuderen met behulp van een basisvragenlijst worden bevraagd en vervolgens jaarlijks met een beperkte jaarkaart waarmee zij mutaties kunnen doorgeven.

In 1990 zijn vier jaargangen oud-studenten van de Rijksuniversiteit Limburg met behulp van de scanner voor de eerste maal geënquêteerd. Het betrof een integrale schriftelijke enquête onder degenen die in de kalenderjaren 1986 tot en met 1989 zijn afgestudeerd. Hierbij werden de jaargangen 1986 tot en met de eerste helft van 1988 benaderd met een eenmalig aangepaste basisvragenlijst, waarbij de loopbaan retrospectief in kaart werd gebracht. Degenen die in de tweede helft van 1988 zijn afgestudeerd alsmede de lichting 1989 werden met behulp van de reguliere basisvragenlijst benaderd.

Met ingang van 1991 zullen deze vier jaargangen afgestudeerden jaarlijks integraal worden geënquêteerd met behulp van de jaarkaart. Door koppeling aan de voorgaande datafiles zal een longitudinaal databestand beschikbaar komen. Hierdoor wordt het mogelijk om, naast dwarsdoorsneden van de arbeidsmarktpositie, ook ontwikkelingen in de loopbaan te traceren. Bovendien kan de intrede op de arbeidsmarkt van nieuwe lichtingen afgestudeerden worden vergeleken met die van de oudere lichtingen. Immers elk jaar worden degenen die in het voorgaande kalenderjaar zijn afgestudeerd, met behulp van de basisvragenlijst voor de eerste keer geënquêteerd. Op deze wijze zal ieder jaar een geactualiseerd databestand beschikbaar komen.

In het rapport is beschreven in hoeverre de in 1986 tot en met 1989 afgestudeerde basisartsen, gezondheidswetenschappers, juristen en economen van de RL verschillend scoren op een aantal dimensies van de arbeidsmarktpositie. Binnen de groep gezondheidswetenschappers is onderscheid gemaakt tussen oud-studenten beleid en beheer van gezondheidszorgvoorzieningen (BB), oud-studenten gezondheidsvoorlichting en -opvoeding (GVO) en oud-studenten verplegingswetenschap (VW). Bij de beschrijving van de onderzochte dimensies van de arbeidsmarktpositie is daarnaast steeds onderscheid gemaakt naar geslacht. Met betrekking tot 
de retrospectief bevraagde deelpopulatie is tevens een aantal ontwikkelingen in de loopbaan getraceerd die het gevolg zijn van functiemobiliteit.

De in dit rapport beschreven dimensies van de arbeidsmarktpositie hebben betrekking op de intrede op de arbeidsmarkt, een aantal kenmerken van de betaalde functie die men thans vervult en de huidige participatie aan het arbeidsproces. De functies zijn getypeerd aan de hand van de werkorganisaties waarin men terecht is gekomen, het beroep dat men uitoefent, het niveau van de werkzaamheden en de aansluiting met de genoten opleiding. Tevens zijn flexibiliteitsindicatoren gepresenteerd die een indruk geven van de uitwijkmogelijkheden naar andere bedrijfssectoren en beroepen. Bij de participatie aan het arbeidsproces is gekeken naar de positie die men op de arbeidsmarkt inneemt, de zekerheid van de baan, de lengte van de werkweek en de potentiële baanmobiliteit. Naast een beschrijving van deze dimensies van de arbeidsmarktpositie, waarbij zoals gezegd steeds onderscheid is gemaakt naar studierichting en naar geslacht, is een aantal kerndimensies van de arbeidsmarktpositie met behulp van multivariate analyses nader onderzocht.

Met nadruk wordt er op gewezen dat waar in dit rapport een invloed van de gevolgde studierichting op de arbeidsmarktpositie wordt vastgesteld, dit betrekking heeft op verschillen in arbeidsmarktpositie tussen de studierichtingen binnen de RL. Het landelijke beeld met betrekking tot de desbetreffende studierichtingen kan hier in meerdere of mindere mate van afwijken. Zo lang de arbeidsmarktscanner nog niet landelijk is toegepast en vergelijkbare gegevens over afgestudeerden van andere universiteiten bijgevolg ontbreken, kan niet worden vastgesteld in hoeverre het hier gepresenteerde beeld van de arbeidsmarktpositie van een studierichting afwijkt van de situatie elders.

In dit afsluitende hoofdstuk worden eerst de belangrijkste bevindingen samengevat met betrekking tot de RL als geheel. In de daaropvolgende paragrafen komen de respectievelijke faculteiten aan bod. Hoewel dit rapport primair het karakter van een onderzoekrapport draagt, worden tot slot enkele terreinen aangegeven, waarop in aansluiting op de onderzoekbevindingen doelgericht beleid zou kunnen worden ontwikkeld en gevoerd.

\subsection{Rijksuniversiteit Limburg}

Intrede op de arbeidsmarkt

De jaren waarin de onderzochte jaargangen afgestudeerden van de $\mathrm{RL}$ op de arbeidsmarkt zijn gekomen, namelijk 1986 tot en met 1989, worden getypeerd door een ongunstige situatie voor 
intredende academici. Aan de aanbodkant van de arbeidsmarkt deed zich in deze jaren een versnelde groei van het aantal universitair geschoolde instromers voor. Aan de vraagzijde manifesteerden zich omvangrijke bezuinigingen in de niet-zakelijke dienstverlening, een belangrijke bron van werkgelegenheid voor afgestudeerden van de RL.

De onderzochte afgestudeerden die in deze jaren de arbeidsmarkt hebben betreden, bestaan voor iets meer dan de helft uit vrouwen. Eenzevende van de afgestudeerden had reeds een HBO of WO opleiding voltooid voordat men aan de RL ging studeren. lets meer dan de helft van de afstudeerders beschikt over extra kwalificaties in de vorm van betaalde werkervaring, meestal als studentassistent opgedaan tijdens de studie aan de RL. Ruim eenderde van de afstudeerders beschikt over extra kwalificaties in de vorm van bestuurlijke ervaring.

Dat de onderzochte jaargangen afgestudeerden zijn geconfronteerd met een voor hen ongunstige situatie op de arbeidsmarkt blijkt uit het verloop van hun intrede gedurende het eerste jaar na afstuderen. Drie maanden na afstuderen verricht $49 \%$ betaald werk. Na een half jaar is het percentage tot 60 opgelopen. Daarna stijgt het aandeel van betaald werkenden tot $71 \%$ én jaar na verlaten van de RL. De tijd die men nodig heeft om de eerste betaalde baan te vinden, geoperationaliseerd door de duur van de intredewerkloosheid, blijkt langer te zijn wanneer men rechten of gezondheidswetenschappen (m.u.v. VW) heeft gestudeerd en wanneer men op oudere leeftijd afstudeert. Afgestudeerden met extra kwalificaties in de vorm van een voltooide vooropleiding op HBO of WO niveau of in de vorm van bestuurlijke ervaring blijken na afstuderen minder lang werkloos te zijn.

\section{Mobiliteit en loopbaan}

In schema 3 komt naar voren dat $37 \%$ van de respondenten na afstuderen nooit -in arbeidsmarkttermen gesproken- mobiel is geweest, omdat men slechts bij én werkgever in éen functie heeft gewerkt. Gebleken is dat $12 \%$ van de respondenten na afstuderen nog geen betaalde baan heeft gehad. Dit impliceert overigens niet dat zij de hele tijd werkloos zijn geweest, omdat zij bijvoorbeeld full time onderwijs kunnen hebben gevolgd. Slechts $2 \%$ van de totale populatie is steeds werkloos geweest.

Degenen die wel mobiel zijn geweest, zijn vaker veranderd van werkgever (baanmobiliteit) dan van functie bij dezelfde werkgever (functiemobiliteit). Bij de retrospectief bevraagde oudstudenten is gebleken dat een aantal van hen via mobiliteit in de loop van hun nog korte beroepscarrière in vaste aanstellingen, in voltijdbanen, in hogere functies en in functies die beter aansluiten met de gevolgde studie terecht is gekomen. 
Schema 3. Resultaten verloop arbeidsmarktpositie afgestudeerden RL

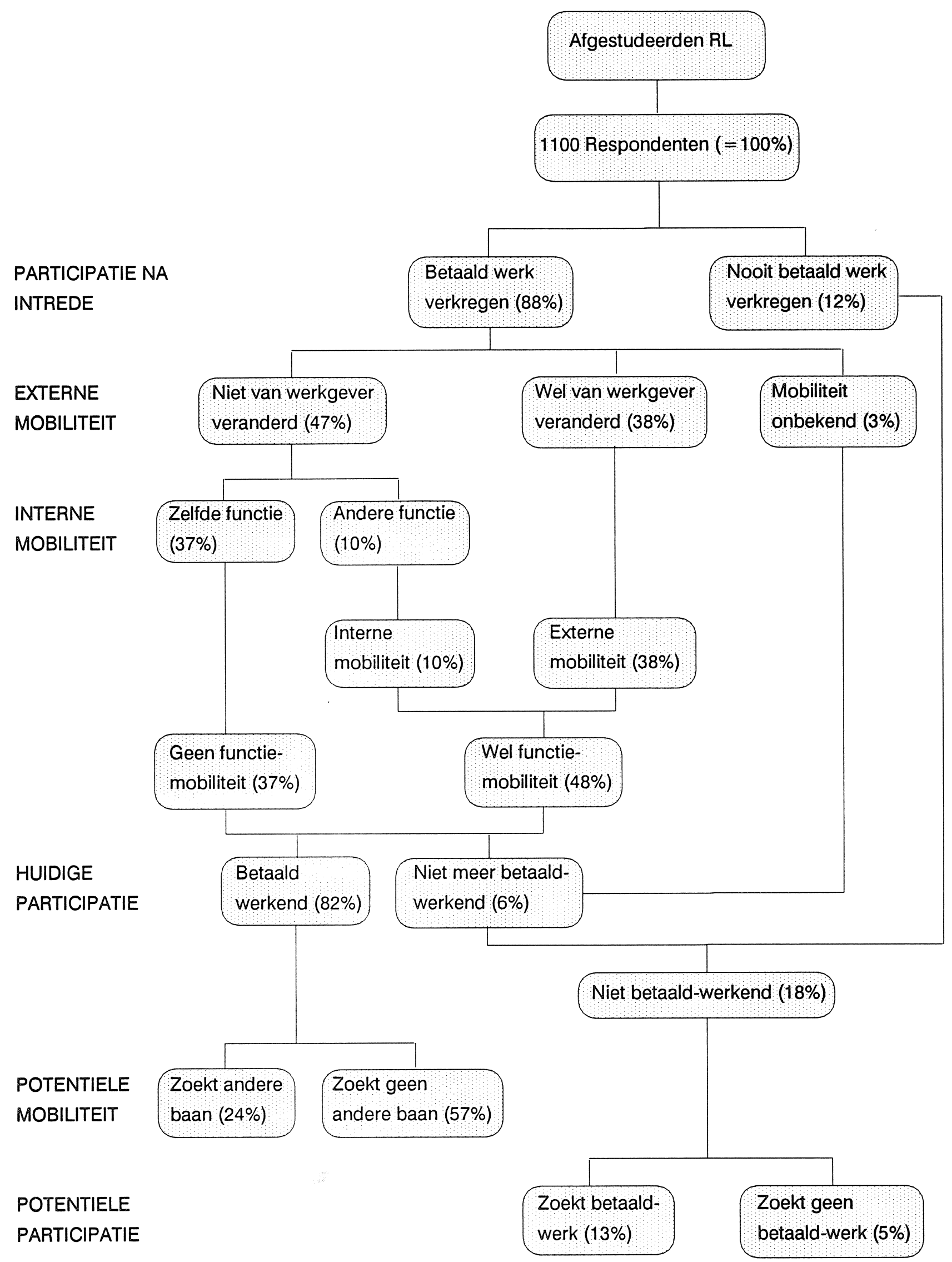




\section{Huidige arbeidsmarktparticipatie}

In schema 3 komt naar voren dat ruim $80 \%$ van de oud-studenten op het moment van enquêtering een betaalde baan heeft. De meeste betaald werkenden $(78 \%)$ hebben vooralsnog een tijdelijke aanstelling. Uit de analyse komt naar voren dat de kans van oud-studenten op het krijgen van betaald werk en het verwerven van een vaste baan mede afhangt van de opleidingsrichting die men heeft gevolgd. Juristen hebben een minder grote kans op een betaalde baan, maar geen kleinere kans dat deze vast is. Economen hebben een grotere kans op een betaalde baan en ook een grotere kans dat deze vast is. Afgestudeerden van de economische variant binnen gezondheidswetenschappen (BB) hebben weliswaar geen grotere kans op een betaalde baan, maar wel een grote kans dat deze baan vast is. Verder blijkt dat de reeds vóór afstuderen opgedane werkervaring, alsmede het aantal jaren dat men reeds is afgestudeerd, de kans op betaald werk vergroten, maar niet van invloed zijn op de kans om een vast dienstverband te krijgen.

Ook uit de beschikbare landelijke gegevens, hoe onvolledig en vervuild deze ook mogen zijn, komt naar voren dat de deelname aan het arbeidsproces bij rechten lager is dan bij geneeskunde en economie.

\section{Huidige functie}

De betaalde functies waarin men op het moment van enquêteren werkt, zijn in dit onderzoek getypeerd aan de hand van de werkorganisaties waarin men terecht is gekomen, het beroep dat men uitoefent, het functieniveau en de aansluiting met de genoten opleiding. Ook is ingegaan op het eventueel gevolgde onderwijs na het afstuderen.

De afgestudeerde basisartsen en gezondheidswetenschappers zijn voor een baan vrijwel uitsluitend aangewezen op de niet-zakelijke dienstverlening, met name gezondheidsdiensten. De onderzochte economen werken vooral in de zakelijke dienstverlening, met name accountantsbureaus. Juristen nemen een tussenpositie in. Zij zijn in vrijwel gelijke mate aangewezen op de niet-zakelijke dienstverlening (met name openbaar bestuur en universiteiten) als op de zakelijke dienstverlening (met name rechtskundige diensten). De analyse van de bedrijfsgroepenspreiding laat zien dat afgestudeerden van de $R L$ veel uitwijkmogelijkheden naar andere bedrijfsgroepen hebben. De werkgelegenheid(sontwikkeling) van de opleidingsrichtingen van de RL hangt bijgevolg niet af van het wel en wee van slechts enkele bedrijfsgroepen. De meerderheid werkt bij grote bedrijven/instellingen. Ruim de helft van de afgestudeerden $(55 \%)$ komt terecht op de Limburgse arbeidsmarkt. Hierbij dient te worden bedacht dat $70 \%$ van de 
betaald werkende respondenten uit Limburg afkomstig is.

De meeste oud-studenten oefenen een wetenschappelijke of andere vakspecialistische functie uit. Basisartsen werken vrijwel uitsluitend in dit soort functies. Gezondheidswetenschappers komen daarnaast ook wel in beleidvoerende functies terecht. Juristen en vooral economen oefenen ook administratieve functies uit. Aangezien de afgestudeerden over het geheel genomen vrij veel uitwijkmogelijkheden naar andere beroepen hebben, kunnen zij vrij flexibel reageren op kleinere verschuivingen in de vraag. Deze flexibiliteit verschilt overigens naar studierichting. Basisartsen wijken het minst vaak uit naar niet bij hun studierichting aansluitende functies; economen en gezondheidswetenschappers doen dit het meest vaak en juristen nemen hierbij een tussenpositie in.

Bij eenvijfde deel van de betaald werkende oud-studenten is sprake van onderbenutting van capaciteiten. Zij oefenen een functie uit waarvoor een opleiding op academisch niveau niet is vereist. In het particuliere bedrijfsleven loopt men een grotere kans op onderbenutting dan bij de overheid met haar wellicht nauwer omschreven selectiecriteria. Deze kans is ook groter in banen waar werken niet wordt gecombineerd met verder leren. De mate waarin men op of onder het opleidingsniveau terecht komt hangt overigens ook af van de opleidingsrichting die men heeft gevolgd. Basisartsen lopen een kleinere kans om onder hun niveau terecht te komen.

Gezien hun nog korte beroepscarrière is het niet verwonderlijk dat nog slechts $29 \%$ van de betaald werkende respondenten een leidinggevende functie uitoefent. Basisartsen zijn wel al vaak leidinggevend werkzaam. Naarmate men langer geleden is afgestudeerd neemt de kans toe dat men een leidinggevende functie heeft verworven. Mannen zijn vaker dan vrouwen in leidinggevende functies werkzaam. Naast het al dan niet leidinggeven vormt ook het inkomen een indicator voor het niveau van de functie. Van de betaald werkenden heeft $38 \%$ een inkomen dat ligt binnen de modale inkomensklasse van $f 3.750,---f 5.000,--$ bruto per maand bij een volledige werkweek. In de uitgevoerde regressie-analyse komt naar voren dat de hoogte van het inkomen mede afhankelijk is van de gevolgde opleidingsrichting. Het inkomen is hoger als men geneeskunde of BB heeft gestudeerd. Het inkomen is ook hoger als men meer jaren arbeidsmarktervaring heeft, wanneer men man is, werkt in een grote arbeidsorganisatie, een vaste aanstelling heeft, wanneer men werkt in een functie op academisch niveau, een leidinggevende functie uitoefent en wanneer men de functie niet combineert met verder leren.

Tweederde volgt verder onderwijs na te zijn afgestudeerd. Het betreft voornamelijk opleidingen die onder de noemer post initieel hoger onderwijs vallen. Bij de meeste van deze opleidingen gaat het om een direct vervolg op de eerste-fase opleiding, namelijk tweede-fase opleidingen 
(exclusief de opleiding tot basisarts) en andere post doctorale opleidingen. De overige opleidingen worden gevolgd als aanvulling op de aan de RL gevolgde eerste-fase opleiding. Naarmate de functie beter aansluit bij de gevolgde studierichting neemt het volgen van vervolgonderwijs toe en (de noodzaak voor) het volgen van aanvullende opleidingen af.

\section{Potentiële mobiliteit}

Uit schema 3 kan worden afgeleid dat bijna eenderde van de betaald werkenden op zoek is naar een andere baan. De neiging van baan te veranderen is groter wanneer men geneeskunde heeft gestudeerd, wanneer men een tijdelijke baan heeft of wanneer men onder zijn of haar niveau werkt. Degenen die 'on the job' een vervolgopleiding doorlopen willen deze ook afmaken. Zij zijn daarom minder vaak op zoek naar een andere baan.

\subsection{Faculteit der Geneeskunde}

Van alle basisartsen die in de periode 1986-1989 zijn afgestudeerd hebben er 330 aan het onderzoek meegewerkt, hetgeen neerkomt op een respons van $85 \%$.

De nominale studieduur bedraagt voor basisartsen niet vier jaar, zoals bij de andere studierichtingen, maar zes jaar. Bij de bevinding dat basisartsen bij afstuderen gemiddeld maar 0,7 jaar ouder zijn dan andere afgestudeerden van de $R L$, dient te worden opgemerkt dat de afgestudeerden van de andere faculteiten vaker reeds een HBO of WO opleiding hadden voltooid voordat zij aan de RL gingen studeren.

Vergeleken met afgestudeerden van de andere studierichtingen blijken basisartsen slechts weinig tijd nodig te hebben om de eerste betaalde baan na afstuderen te vinden. Meer dan de helft van de basisartsen ( $55 \%$ ) heeft binnen drie maanden na afstuderen een betaalde baan gevonden; éen jaar na verlaten van de RL is het percentage al opgelopen tot $80 \%$. Zij verwerven de eerste baan relatief vaak via open sollicitaties.

In schema 4 komt naar voren dat $89 \%$ van de basisartsen thans een betaalde baan heeft. Van de betaald werkende basisartsen heeft $12 \%$ een vaste baan. Basisartsen hebben geen grotere of kleinere kans op betaald werk of op een vaste baan dan de andere afgestudeerden. Basisartsen maken overigens lange werkweken. Bijna de helft $(47 \%)$ werkt meer dan veertig uur per week. 
Schema 4. Resultaten verloop arbeidsmarktpositie afgestudeerden FdG

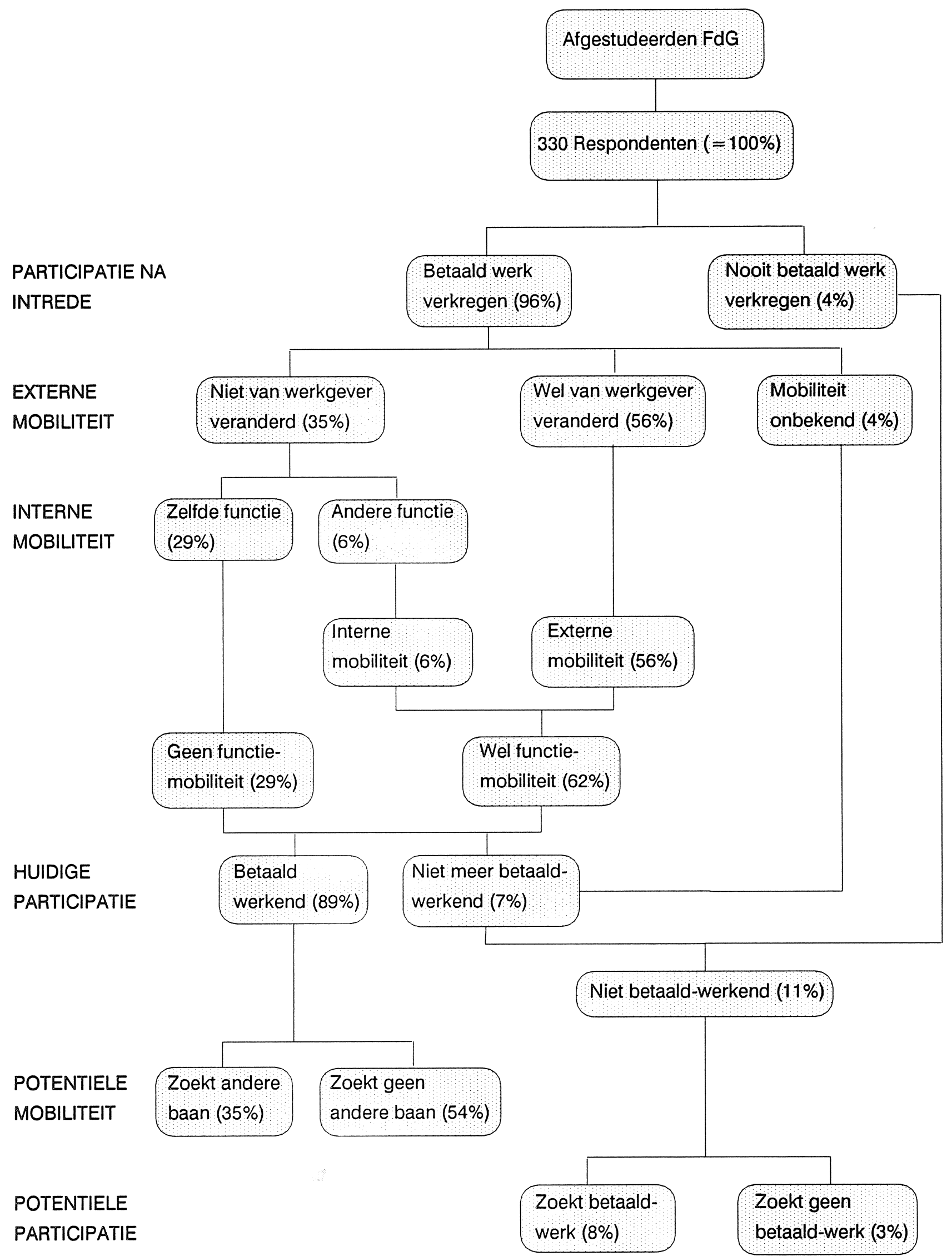


$-95-$

Het merendeel $(60 \%)$ van de betaald werkende basisartsen komt terecht in grote werkorganisaties met meer dan 99 personeelsleden (met name ziekenhuizen); eenvijfde werkt in organisaties met minder dan tien personeelsleden (met name huisartsenpraktijken). Voor een baan zijn de meesten (78\%) aangewezen op de bedrijfsklasse gezondheidsdiensten. Elf procent werkt in het buitenland, meestal in het kader van ontwikkelingssamenwerking.

Basisartsen oefenen vrijwel uitsluitend wetenschappelijke of andere vakspecialistische functies op medisch terrein uit. Zij zijn dan ook over een relatief klein aantal beroepen verspreid. De lage beroepenspreiding en het lage percentage werkloze basisartsen wijst op voldoende vraag naar afgestudeerden van de studierichting geneeskunde in hun 'eigen' beroependomein. Basisartsen hoeven derhalve niet zo vaak uit te wijken naar niet bij hun studierichting aansluitende beroepen. Vormt het vinden van een (medische) baan voor basisartsen over het geheel genomen dus geen probleem, het vinden van een opleidingsplaats voor medisch specialist is wel degelijk problematisch: slechts $17 \%$ van alle onderzochte basisartsen volgt thans een specialistenopleiding en $40 \%$ van de betaalde werkende basisartsen zoekt een andere baan, waarschijnlijk een opleidingsplaats voor medisch specialist (zie schema 4).

Met betrekking tot het niveau van de functie komt naar voren dat van de betaald werkende basisartsen $99 \%$ een functie uitoefent waarvoor een academische opleiding is vereist, $34 \%$ een leidinggevende functie uitoefent en $52 \%$ een bruto maandinkomen (op basis van een volledige werkweek) verwerft dat ligt binnen de voor de onderzochte basisartsen modale inkomensklasse van $f 3.750,---f 5.000,--$. De inkomensspreiding is dus groot.

\subsection{Faculteit der Gezondheidswetenschappen}

Van alle gezondheidswetenschappers die in de periode 1986-1989 zijn afgestudeerd, hebben er 385 aan het onderzoek meegewerkt. Dit komt neer op een respons van $85 \%$. Gezien de nog recente start van het onderwijs in gezondheidswetenschappen aan de RL zijn de aantallen afgestudeerden in de andere afstudeerrichtingen dan BB, GVO en VW nog te gering om uitsplitsingen naar deze varianten te maken. Van de geënquêteerde gezondheidswetenschappers is $34 \%$ afgestudeerd in BB, $23 \%$ in GVO en $20 \%$ in VW. Karakteristiek voor de populatie van afgestudeerde gezondheidswetenschappers is het hoge aandeel van vrouwen (75\%). 
Schema 5. Resultaten verloop arbeidsmarktpositie afgestudeerden FdGW

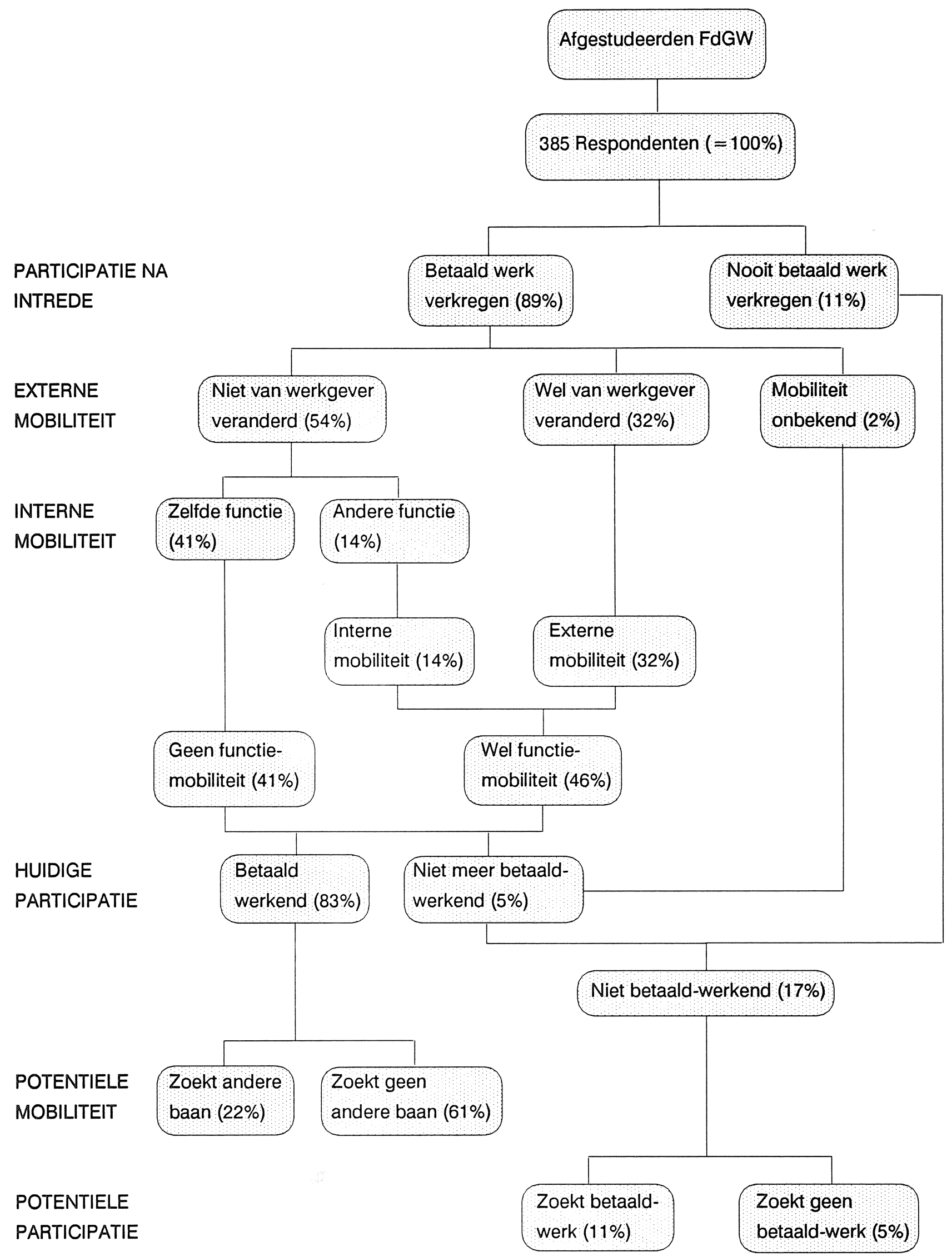


De intrede van gezondheidswetenschappers op de arbeidsmarkt verloopt gedurende het eerste jaar als volgt. Drie maanden na afstuderen heeft $49 \%$ betaald werk gevonden. Na zes maanden is het percentage opgelopen tot 58 om daarna te stijgen tot $70 \%$ één jaar na verlaten van de RL. De duur van de intredewerkloosheid blijkt relatief lang te zijn wanneer men gezondheidswetenschappen (met uitzondering van VW) heeft gestudeerd. Gezondheidswetenschappers verwerven overigens de eerste baan relatief vaak door op vacature-advertenties te solliciteren en relatief zelden via open sollicitaties, zoals medici en economen.

Uit schema 5 komt naar voren dat $41 \%$ na afstuderen nog niet van functie is veranderd, omdat men nog slechts bij één werkgever in één functie heeft gewerkt; $11 \%$ heeft nog niet betaald gewerkt.

$\mathrm{Na}$ een aanvankelijk tamelijk moeizaam verlopende intrede op de arbeidsmarkt, weten gezondheidswetenschappers hun arbeidsmarktpositie sterk te verbeteren. In schema 5 staat aangegeven dat $83 \%$ van de gezondheidswetenschappers thans een betaalde baan heeft, waarvan $24 \%$ een vaste baan betreft. Maakt het voor de kans op een betaalde baan niet uit welke afstudeerrichting men binnen gezondheidswetenschappen heeft gevolgd, de kans op een vaste baan blijkt groter te zijn wanneer men BB heeft gestudeerd. Van de betaald werkende oudstudenten BB heeft $33 \%$ een vaste baan.

Van de betaald werkende gezondheidswetenschappers werkt de meerderheid $(61 \%)$ in grote organisaties met meer dan 99 personeelsleden en komen de meesten (55\%) in provincies buiten Limburg terecht. De meeste gezondheidswetenschappers (83\%) zijn voor een baan aangewezen op de niet-zakelijke dienstverlenende sector. Afgestudeerden BB zijn met $76 \%$ het minst sterk op de niet-zakelijke dienstverlening aangewezen en over het grootste aantal bedrijfssectoren verspreid. Hun werkgelegenheid is geconcentreerd in sectoren die behoren tot de bedrijfsklassen 'gezondheidsdiensten' (49\%), 'onderwijs' (13\%), 'verzekeringswezen' (10\%) en 'zakelijke dienstverlening' (eveneens 10\%). Afgestudeerden GVO en VW komen vrijwel uitsluitend (respectievelijk met $90 \%$ en $89 \%$ ) in de niet-zakelijke dienstverlening terecht, met name in de bedrijfsklassen 'gezondheidsdiensten' (respectievelijk $45 \%$ en $49 \%$ ) en 'onderwijs' (beiden met $27 \%)$

De meerderheid $(63 \%)$ van de betaald werkende oud-studenten BB werkt als beleidsmedewerker, bedrijfsorganisatiedeskundige, administratieve automatiseringsdeskundige, econoom of als sociaal-wetenschappelijk onderzoeker. Afgestudeerden GVO werken het meest vaak als medisch-maatschappelijk werker $(41 \%)$ of sociaal-wetenschappelijk onderzoeker (18\%). De meeste betaald werkende oud-studenten VW $(64 \%)$ oefenen een van de volgende vijf beroepen 
uit: staffunctionaris verpleging, medisch-beleidsmedewerker, docent (para)medische vakken, (para)medisch-wetenschappelijk onderzoeker en sociaal-wetenschappelijk onderzoeker.

Een substantieel deel $(41 \%)$ van de betaald werkende gezondheidswetenschappers heeft een functie waarvoor hun studierichting niet specifiek is vereist. Dit is met name bij oud-studenten BB het geval. Dit kan wijzen op zowel uitwijkmogelijkheden naar andere beroepen als gevoeligheid voor concurrentie door afgestudeerden van verwante studierichtingen. De grotere beroepenspreiding van met name de opleidingsrichtingen BB en VW wijst, in combinatie met het lage percentage werklozen, op veel uitwijkmogelijkheden zowel binnen als buiten het 'eigen' beroependomein, waardoor de werkloosheidsgevoeligheid van de betreffende opleidingsrichtingen vermoedelijk laag is.

Met betrekking tot het niveau van de functie komt naar voren dat van de betaald werkende gezondheidswetenschappers $73 \%$ een functie uitoefent waarvoor een academische opleiding is vereist (waarbij dus geen sprake is van onderbenutting van capaciteiten), $23 \%$ een leidinggevende functie uitoefent en $38 \%$ een bruto maandinkomen verwerft dat ligt binnen de voor gezondheidswetenschappers modale inkomensklasse van $f 3.000,---f 3.750,--$ lop basis van een volledige werkweek).

Maakt het voor de kans op onderbenutting en leidinggeven niet uit welke afstudeerrichting men binnen gezondheidswetenschappen heeft gevolgd, het inkomen blijkt hoger te zijn wanneer men BB heeft gestudeerd. Ondanks hun hogere inkomen zijn oud-studenten BB echter niet minder dan andere gezondheidswetenschappers genegen van baan te veranderen. Uit het schema komt naar voren dat $27 \%$ van de betaald werkende gezondheidswetenschappers een andere baan aan het zoeken is.

\subsection{Faculteit der Rechtsgeleerdheid}

Van de juristen die in de periode 1986-1989 aan de RL afstudeerden, hebben er 343 aan het onderzoek meegewerkt hetgeen neerkomt op een respons van $72 \%$. 
Schema 6. Resultaten verloop arbeidsmarktpositie afgestudeerden FdR

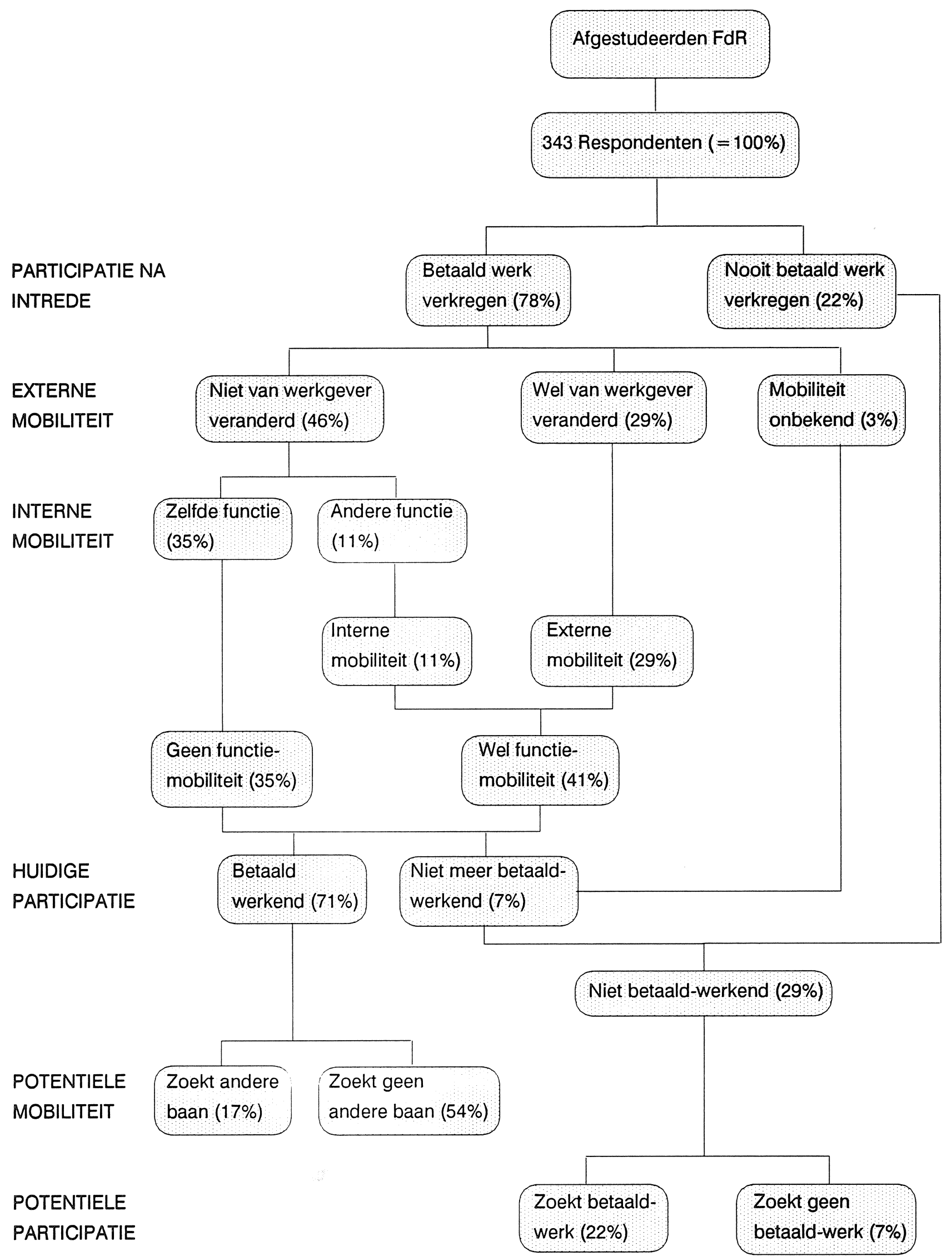


De intrede van juristen op de arbeidsmarkt verloopt als volgt. Drie maanden na afstuderen heeft $39 \%$ een betaalde baan gevonden. Na zes maanden bedraagt het percentage 48 , om daarna te stijgen tot $60 \%$ éen jaar na verlaten van de RL. Uit schema 6 blijkt dat op het moment van enquêteren $71 \%$ betaald werk heeft gevonden. Uit de analyse komt naar voren dat de duur van de intredewerkloosheid relatief lang is, en de kans op een betaalde baan relatief klein is, wanneer men rechten heeft gestudeerd. Overigens hebben juristen weliswaar een kleinere kans op een betaalde baan, maar de kans dat deze baan vast is, is niet kleiner. Ruim een kwart $(27 \%)$ van de betaald werkende juristen heeft een vaste baan gevonden. Gebleken is dat juristen hun eerste baan relatief zelden via open sollicitaties verwerven, zoals medici en economen, maar vaak door, evenals gezondheidswetenschappers, op vacature-advertenties te solliciteren.

Uit schema 6 komt naar voren dat ruim eenderde (35\%) na afstuderen nog niet van functie is veranderd, omdat men nog slechts bij én werkgever in één functie heeft gewerkt; $22 \%$ heeft nog niet betaald gewerkt.

Voor een baan zijn juristen in vrijwel gelijke mate aangewezen op de niet-zakelijke dienstverlening $(48 \%)$ - met name openbaar bestuur en onderwijs - als op de bedrijfstak 'banken verzekeringswezen en zakelijke dienstverlening' (42\%), met name rechtskundige diensten. De helft van de betaald werkende juristen $(51 \%)$ werkt in grote organisaties met meer dan 99 werknemers. Eenvijfde werkt in kleine organisaties met minder dan 10 personeelsleden, met name advocatenkantoren. De meerderheid $(70 \%)$ van de betaald werkenden komt terecht op de Limburgse arbeidsmarkt.

Meer dan de helft (59\%) van de betaald werkende juristen oefent het beroep van jurist uit. De rest komt vooral in administratieve functies terecht. lets meer dan eenderde (35\%) geeft te kennen dat hun functie ook door juristen met een andere afstudeerrichting dan Nederlands recht kan worden vervuld. Dit maakt hen gevoelig voor concurrentie van elders opgeleide juristen. Ondanks de bevinding dat zij al over vrij veel beroepen binnen het 'eigen' beroependomein zijn verspreid, is de werkloosheid onder de onderzochte juristen relatief hoog. Mogelijk slagen zij er in onvoldoende mate in om buiten het 'eigen' beroependomein werk te vinden. De meerderheid (73\%) werkt immers in functies waarvoor een rechtenopleiding specifiek is vereist.

Met betrekking tot het niveau van de functie komt naar voren dat $79 \%$ van de betaald werkende juristen een functie uitoefent waarvoor een academische opleiding is vereist, $27 \%$ een leidinggevende functie uitoefent en $37 \%$ een bruto maandinkomen verwerft dat ligt binnen de voor de onderzochte juristen modale inkomensklasse van $f 3.000,--f 3.750,--$, bij een 
$-101-$

volledige werkweek. Uit het schema blijkt dat $23 \%$ van de betaald werkende juristen een andere baan aan het zoeken is.

\subsection{Faculteit der Economische Wetenschappen}

Gezien de nog recente start van het economie-onderwijs aan de RL in 1984, gaat het bij de tot nu onderzochte jaargangen om de eerste lichtingen afgestudeerden van deze faculteit. Dit heeft tot gevolg dat er nog slechts 42 economen zijn geënquêteerd, hetgeen neerkomt op een respons van $91 \%$. Karakteristiek voor de populatie van afgestudeerde economen is het lage aandeel van vrouwen $(21 \%)$ en het hoge aandeel dat als student-assistent betaalde werkervaring vóór afstuderen heeft opgedaan ('eerste lichting' effect).

Wanneer men economie heeft gestudeerd, heeft men slechts weinig tijd nodig om de eerste betaalde baan na afstuderen te vinden: driekwart van de economen (76\%) heeft na én maand een betaalde baan. Drie maanden na afstuderen bedraagt het percentage 83 en één jaar na verlaten van de RL heeft $95 \%$ betaald werk. De helft van de onderzochte economen verwerft de eerste baan, evenals de basisartsen, via open sollicitaties.

Uit schema 7 komt naar voren dat de overgrote meerderheid (76\%) na afstuderen nog niet van baan is veranderd, omdat men nog slechts bij én werkgever in één functie heeft gewerkt; $7 \%$ heeft nog niet betaald gewerkt.

Economen hebben niet alleen een grote kans op betaald werk maar ook een grote kans op een vaste aanstelling. In het schema staat aangegeven dat vrijwel alle economen (93\%) thans een betaalde baan hebben; ruim de helft $(58 \%)$ van de betaald werkende economen heeft een vaste baan. Met betrekking tot de korte duur van de intredewerkloosheid en de grote kans op werk dient er wel op te worden gewezen dat het gaat om de eerste lichtingen afgestudeerde economen, waarvan $21 \%$ een betaalde baan als $\mathrm{AlO}$ aan deze faculteit heeft gekregen en $39 \%$ als (assistent) accountant werkt.

Voor een baan zijn de onderzochte economen in hoge mate aangewezen op de bedrijfsklassen zakelijke dienstverlening ( $39 \%$ werkt in accountantsbureaus) en onderwijs (24\%), alsmede op de bedrijfstak industrie $(21 \%)$. De overgrote meerderheid van de betaald werkende economen $(79 \%)$ werkt in grote organisaties met meer dan 99 werknemers; $57 \%$ komt terecht op de Limburgse arbeidsmarkt. Hiertoe behoort ook een aantal van de eerste lichtingen economen dat als $\mathrm{AIO}$ aan de $\mathrm{RL}$ is gaan werken. 
Schema 7. Resultaten verloop arbeidsmarktpositie afgestudeerden FdEW

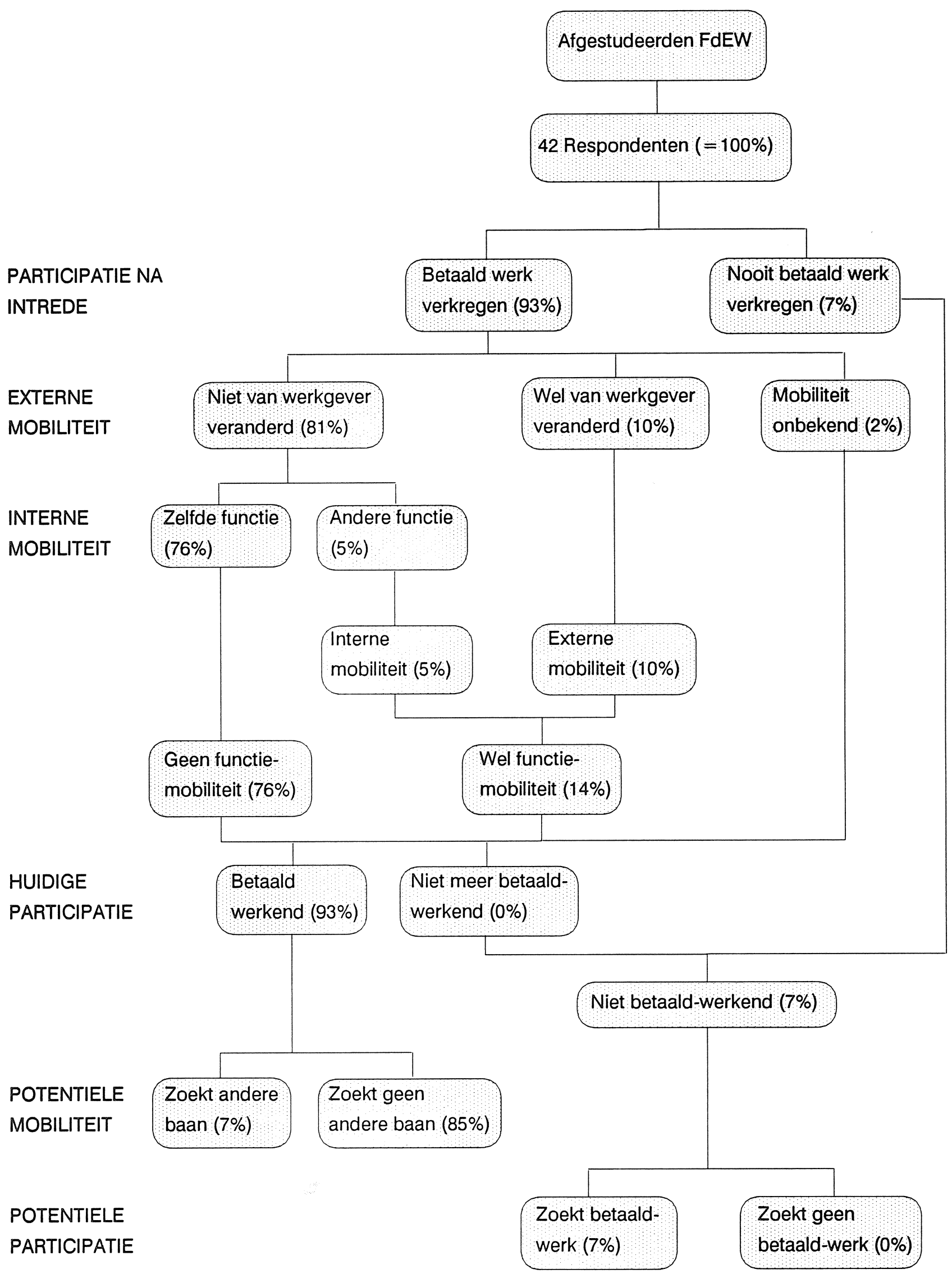


De meerderheid van de betaald werkende economen oefent het beroep van econoom uit $135 \%$, waarvan $21 \%$ als $\mathrm{AlO}$ ) of werkt als (assistent) accountant en volgt daarnaast de postdoctorale beroepsopleiding accountancy $(39 \%)$. Slechts eenderde oefent een functie uit waarvoor economie of een daaraan verwante studierichting is vereist. Dit maakt vervanging en concurrentie mogelijk door afgestudeerden van verwante studierichtingen.

Met betrekking tot het niveau van de functie komt naar voren dat $76 \%$ van de betaald werkende economen een functie uitoefent waarvoor een academische opleiding is vereist, $27 \%$ een leidinggevende functie uitoefent en $42 \%$ een bruto maandinkomen verwerft dat ligt binnen de voor de onderzochte economen modale inkomensklasse van $f 3.000,--f 3.750,--$ bij een volledige werkweek. Uit het schema blijkt dat $8 \%$ van de betaald werkende economen een andere baan aan het zoeken is. Dit lage percentage wordt verklaard door het grote aantal economen dat als accountant of AIO verder leert en deze opleiding eerst wil voltooien voordat men een andere baan gaat zoeken.

\subsection{Implicaties voor beleid}

De in dit onderzoekrapport gepresenteerde resultaten hebben betrekking op de arbeidsmarktpositie van vooralsnog vier jaargangen afgestudeerden van de RL. In het rapport is een aanzet gegeven tot het in kaart brengen van de loopbaanontwikkeling van de opeenvolgende cohorten afgestudeerden. Een longitudinale onderzoekbenadering is echter pas goed mogelijk wanneer de arbeidsmarktscanner over een groter aantal jaren zal zijn toegepast. Hierdoor kunnen de arbeidsmarktpositie van een groter aantal cohorten en de loopbanen over een groter aantal jaren in kaart worden gebracht. Het zal dan bovendien mogelijk zijn om in overleg met de desbetreffende faculteit geselecteerde thema's betreffende de aansluiting van de functie met de gevolgde studie diepgaander te onderzoeken. Voor dit doel kan de standaardbevraging vijfjaarlijks worden uitgebreid.

Desalnietemin is het nu reeds mogelijk enkele terreinen te noemen waarop, mede naar aanleiding van de onderzoekbevindingen, doelgericht beleid zou kunnen worden gevoerd. De onderzoekers doen hierbij slechts suggesties voor eventuele terreinen waarop beleidsmatige keuzen mogelijk zijn. De verantwoordelijkheden voor de beleidskeuzen liggen uiteraard elders. De te noemen beleidsterreinen kunnen zich direct richten op studenten of op facultaire beleidsmakers. Op studenten gerichte beleidsmaatregelen liggen op het terrein van voorlichting en stages en voor aspirant-afstudeerders op het terrein van arbeidsmarktoriëntatie, solliciteerstrategie en loopbaanadvisering. Ten behoeve van deze doelgroepen kan aan de hand van de verkregen onderzoekresultaten bijvoorbeeld worden gewezen op de belangrijkste 
beroepen en bronnen van werkgelegenheid en daarmee van stageplaatsen voor de desbetreffende opleidingsrichting, op het belang van het opdoen van bestuurlijke ervaring en open sollicitaties voor een succesvolle intrede op de arbeidsmarkt en op de bevinding dat een aantal oudstudenten in de loop van hun nog korte beroepscarrière terecht is gekomen in vaste aanstellingen, in voltijdbanen, in hogere functies en in functies die beter aansluiten bij de gevolgde studie. Diepgaander inzicht in de loopbaanontwikkeling kan uiteraard pas worden verkregen wanneer de arbeidsmarktscanner, zoals gezegd, over een groter aantal jaren zal zijn toegepast. Aan bovengenoemde beleidsterreinen zou, gebaseerd op een gezamenlijk plan van aanpak, in een daarvoor in het leven geroepen voorziening vorm kunnen worden gegeven. In dit verband kan bijvoorbeeld worden gewezen op het Loopbaan Advies Centrum (LAC) dat dit jaar aan de Universiteit van Amsterdam van start is gegaan. In het LAC vindt loopbaanadvisering op een gecoördineerde en gestructureerde wijze plaats.

Gezien de onderzoekbevinding dat slechts weinig afgestudeerden in het buitenland terecht komen, zouden maatregelen kunnen worden overwogen om sterker in te spelen op de Euregionale lokatie van de RL. In opdracht van de Europese Commissie heeft het ROA onderzocht op welke wijze universitaire afgestudeerden kunnen worden geholpen bij het vinden van een baan in het buitenland. Naar voren kwam dat de meeste suggesties van Nederlandse universiteiten onder twee noemers vallen: het scheppen van meer werkervaringsplaatsen in het buitenland (met name internationale stage-uitwisselingsprogramma's, bijvoorbeeld door bestaande studentenuitwisselingsprogramma's als ERASMUS uit te breiden met stages) en het stimuleren van afstudeerders om in het buitenland te solliciteren (bijvoorbeeld door hen te trainen in de wijze waarop men naar een buitenlandse baan solliciteert ${ }^{26}$. Men zou door middel van stages in andere Nederlandse provincies en stimuleren om buiten Limburg te solliciteren eveneens kunnen bevorderen dat afgestudeerden, in het bijzonder juristen, zich meer op de landelijke arbeidsmarkt gaan oriënteren en minder op Limburg.

Met betrekking tot de eerste lichtingen economen hebben zich weinig of geen problemen voorgedaan. Hierbij moet wel worden bedacht dat het nog om zeer weinig economen gaat, waarvan een aantal bovendien een baan aan de RL heeft gekregen. Of de arbeidsmarktintrede van economen zo probleemloos blijft verlopen wanneer straks grotere aantallen afstuderen, is nog maar de vraag. Hierbij komt dat uit het onderzoek is gebleken dat eenderde deel van de bevraagde economen een functie uitoefent die ook door afgestudeerden van concurrerende studierichtingen kan worden vervuld. Ook gezondheidswetenschappers (met name oudstudenten BB) werken vaak in functies die ook door afgestudeerden van concurrerende

26. Ramaekers (1990-II). 
studierichtingen kunnen worden vervuld $157 \%$ van de betaald werkende oud-studenten BB heeft een functie waarvoor de gevolgde studierichting niet specifiek is vereist).

Gezien het voorgaande zou aan facultaire beleidsmakers in overweging kunnen worden gegeven of men zich het beeld van beroepen en sectoren, zoals dit naar voren is gekomen, ook had voorgesteld bij het ontwikkelen van het studieprogramma en zo ja of men dit wil handhaven of niet. Met betrekking tot juristen is bijvoorbeeld naar voren gekomen dat men weinig uitwijkmogelijkheden buiten het 'eigen' beroependomein heeft, terwijl men binnen het 'eigen' domein concurrentie ondervindt van elders opgeleide juristen.

De bevinding dat bij de hierboven genoemde studierichtingen kennelijk in veel gevallen substitutie mogelijk is door andere studie- of afstudeerrichtingen, zou aanleiding kunnen zijn tot een discussie over de vraag of een verdieping van het kwalificatieprofiel is gewenst, teneinde concurrentie door anders opgeleiden te verminderen londer verkleining van het 'eigen' beroependomein), of dat juist het beroependomein moet worden vergroot door combinaties met aanpalende disciplines aan te gaan.

Voor basisartsen vormt het vinden van een post-basisarts opleidingsplaats het grootste knelpunt. De moeilijkheid bij beleidsmaatregelen die er op zijn gericht om het aantal opleidingsplaatsen te vergroten (indien men dat gewenst acht), is evenwel dat hierbij veel partijen met uiteenlopende belangen betrokken zijn (beroepsverenigingen van medisch specialisten, ziekenhuizen, Ministerie van Welzijn, Volksgezondheid en Cultuur).

Eerder is er reeds op gewezen dat de in dit rapport gepresenteerde studierichtingspecifieke onderzoekresultaten alleen betrekking hebben op de verschillen in arbeidsmarktpositie tussen de studierichtingen binnen de RL. Het verdient dan ook aanbeveling om de arbeidsmarktscanner landelijk toe te passen. Dit maakt het mogelijk om landelijke, al dan niet studiecluster-specifieke rapportages op te stellen, waarin een onderscheid naar studierichting wordt gemaakt en waarmee de resultaten met betrekking tot de eigen instelling kunnen worden vergeleken. Door deze aanpak wordt het mogelijk een scherper beeld te krijgen van de vraag in hoeverre de arbeidsmarktpositie van de afgestudeerden instellingsspecifiek is, dan wel gedomineerd wordt door de landelijk situatie met betrekking tot de desbetreffende studierichtingen. Een dergelijke landelijke aanpak wordt momenteel door het HBO gevolgd. 


$$
\ldots
$$




\section{LITERATUUR}

Bruyn-Hundt, M (1988), Vrouwen op de arbeidsmarkt, Utrecht.

Cox, D.R., D. Oakes (1984), Analysis of Survival Data, Londen.

Dam, J.W. van, A. de Grip, J.A.M. Heijke (1988), Op zoek naar informatiebronnen over de arbeidsmarktpositie van academici, ROA-W-1988/3, Maastricht.

Dam, J.W. van, J.A.M. Heijke, G.W.M. Ramaekers (1989), Ontwerp van een arbeidsmarktscanner voor academici, ROA-R-1989/3, Maastricht.

Dam, J.W. van, A. de Grip, J.A.M. Heijke (1990), Huidig follow-up onderzoek levert dikwijls beperkte resultaten, in: Universiteit en Hogeschool, jrg. 36, nr. 4, p. 260-266.

Dam, J.W. van, J.A.M. Heijke, G.W.M. Ramaekers (1990), Gecoördineerd arbeidsmarktonderzoek onder hoger opgeleiden: methodiek en resultaat. Naar vergelijkbaarheid door standaardisatie, in: Universiteit en Hogeschool, jrg. 37, nr. 2, p. 82-91.

Grip, A. de (1987), Onderwijs en Arbeidsmarkt: Scholingsdiscrepanties, VU-uitgeverij, Amsterdam.

Grip, A. de, R.K.W. van der Velden, M.H. Wieling (1991), Indicatoren aans/uiting onderwijsarbeidsmarkt MDGO. Enkele arbeidsmarktindicatoren op basis van de RUBS-data, ROA-R1991/2, Maastricht.

Kalbfleisch, J.D., R.L. Prentice (1980), The statistical analysis of failure time data, John Wiley and sons, New York.

Lancaster, T (1979), Econometric models for the duration of unemployment, in: Econometrica, jrg. 47, pp. 939-979.

Meesters, M.J., J.M. Huson (1990), Schoolloopbanen en arbeidsmarktpositie, Leiden.

Ministerie van Onderwijs en Wetenschappen (1991), Feiten en cijfers 1991, Den Haag.

Nieuwenhuysen, W. van, R. Wielers (1990), De arbeidsmarktpositie van intredende academici, RION, Groningen.

Ours, J. van (1990), An international comparative study on job mobility, in: Labour. Review of labour economics and industrial relations, volume 4, nr.3, pp. 33-57.

Ramaekers, G.W.M., J.A.M. Heijke (1990-I), Proefonderzoek arbeidsmarktscanner afgestudeerden Rijksuniversiteit Limburg, ROA-W-1990/3, Maastricht.

Ramaekers, G.W.M., J.A.M. Heijke (1990-II), Arbeidsmarktscanner afgestudeerden Rijksuniversiteit Limburg. Presentatie van het onderzoekinstrument en verslag van de eerste integrale meting, ROA, Maastricht. Intern verslag.

Ramaekers, G.W.M. (1990-I), Arbeidsmarktscanner Rijksuniversiteit Limburg. Afgestudeerden januari 1986 - juni 1988. Verslag ten behoeve van het College van Bestuur, ROA, Maastricht. Intern verslag. 
Ramaekers, G.W.M. (1991), Arbeidsmarktscanner Rijksuniversiteit Limburg. Afgestudeerden 1989. Verslag ten behoeve van het College van Bestuur, ROA, Maastricht. Intern verslag.

Ramaekers, G.W.M. (1990-II), Entry of Dutch graduates to the European Community Labour Market, ROA-R-1990/7E, Maastricht.

Rijksuniversiteit Limburg (1988), Ontwikkelingsplan 1989-1992 Rijksuniversiteit Limburg, Maastricht.

Schut, W.W., F.Y. Dijkstra, Arbeidsmarkt en academici 1947-1985, Ministerie van Onderwijs en Wetenschappen, Directie Toekomstverkenningen. 


\section{BIJLAGE 1. TABELLEN}

Tabel 1. Belangstelling voor mogelijke activiteiten met betrekking tot afgestudeerden, naar faculteit (in $\%$ van de totale populaties); meer antwoorden mogelijk

\begin{tabular}{|c|c|c|c|c|c|}
\hline \multirow[b]{2}{*}{ Activiteiten } & \multirow[b]{2}{*}{ FdG } & \multicolumn{3}{|c|}{$\%$ dat belangstelling heeft } & \multirow{2}{*}{ Totaal } \\
\hline & & FdGW & FdR & FdEW & \\
\hline Reünie van jaar- en/of studiegenoten & 63 & 58 & 57 & 67 & 60 \\
\hline Tijdschrift voor afgestudeerden & 51 & 64 & 63 & 79 & 60 \\
\hline $\begin{array}{l}\text { Notatie in jaarlijkse adressenlijst voor } \\
\text { afgestudeerden van de desbetreffende } \\
\text { faculteit }\end{array}$ & 40 & 50 & 50 & 71 & 48 \\
\hline $\begin{array}{l}\text { Themadag voor afgestudeerden van de } \\
\text { desbetreffende faculteit }\end{array}$ & 22 & 46 & 35 & 62 & 36 \\
\hline $\begin{array}{l}\text { Post academisch onderwijs voor afgestu- } \\
\text { deerden van de desbetreffende faculteit }\end{array}$ & 21 & 39 & 23 & 17 & 28 \\
\hline Opname in sollicitantenbank & 19 & 26 & 23 & 10 & 22 \\
\hline $\begin{array}{l}\text { Voorlichting geven aan studenten in de } \\
\text { desbetreffende faculteit over praktijk } \\
\text { na afstuderen }\end{array}$ & 22 & 22 & 17 & 26 & 21 \\
\hline Geen activiteit & 11 & 7 & 10 & 12 & 10 \\
\hline
\end{tabular}

In tabel 1 komt naar voren dat de overgrote meerderheid van de oud-studenten belangstelling heeft voor activiteiten die worden georganiseerd door de universiteit waar men heeft gestudeerd. De grootste belangstelling blijkt te bestaan voor zaken die de binding met de universiteit versterken, zoals reünies, een magazine voor afgestudeerden en een adressenlijst van oud-studenten. De twee genoemde vakinhoudelijke activiteiten, een themadag en postacademisch onderwijs, scoren lager in de belangstelling. Dit is met name bij oud-studenten van de Faculteit der Geneeskunde het geval. Het gegeven dat basisartsen doorgaans buiten de eigen universiteit een specifieke vervolgopleiding voor medisch specialist kiezen zal hier wellicht niet vreemd aan zijn. Voor de maatregel ter bevordering van plaatsing op de arbeidsmarkt bestaat duidelijk minder belangstelling. Dit houdt verband met het feit dat de meeste respondenten op het moment van de bevraging een betaalde baan hebben gevonden waardoor de behoefte aan een dergelijke maatregel is komen te vervallen. 
Tabel 2. Representativiteit van de facultaire deelpopulaties naar afstudeerjaar (stand van de respons op 15-3-1991)

\begin{tabular}{|c|c|c|c|c|c|}
\hline & \multicolumn{2}{|c|}{ Afgestudeerden } & \multicolumn{2}{|c|}{ Respondenten } & $\begin{array}{r}\text { Respons } \\
\%\end{array}$ \\
\hline \multicolumn{6}{|l|}{$F d G$} \\
\hline 1986 & 75 & 19 & 63 & 19 & 84 \\
\hline 1987 & 83 & 21 & 69 & 21 & 83 \\
\hline 1988 & 115 & 30 & 104 & 32 & 90 \\
\hline 1989 & 116 & 30 & 94 & 29 & 81 \\
\hline Totaal & 389 & 100 & 330 & 101 & 85 \\
\hline \multicolumn{6}{|l|}{$F d G W$} \\
\hline 1986 & 92 & 20 & 68 & 18 & 74 \\
\hline 1987 & 92 & 20 & 79 & 21 & 86 \\
\hline 1988 & 127 & 28 & 114 & 30 & 90 \\
\hline 1989 & 141 & 31 & 123 & 32 & 87 \\
\hline Totaal & 452 & 99 & 385 & 101 & 85 \\
\hline \multicolumn{6}{|l|}{$F d R$} \\
\hline 1986 & 61 & 13 & 41 & 12 & 67 \\
\hline 1987 & 122 & 26 & 80 & 23 & 66 \\
\hline 1988 & 165 & 35 & 118 & 34 & 72 \\
\hline 1989 & 127 & 27 & 104 & 30 & 82 \\
\hline Totaal & 475 & 101 & 343 & 99 & 72 \\
\hline \multicolumn{6}{|l|}{ FdEW* } \\
\hline 1988 & 17 & 37 & 17 & 41 & 100 \\
\hline 1989 & 29 & 63 & 25 & 60 & 86 \\
\hline Totaal & 46 & 100 & 42 & 101 & 91 \\
\hline
\end{tabular}

* Aan deze faculteit studeerden voor het eerst in 1988 studenten af.

Tabel 3. Hoogste voltooide vooropleiding (in \%)

\begin{tabular}{|c|c|c|c|c|c|}
\hline \multirow[b]{2}{*}{ Vooropleiding } & \multirow[b]{2}{*}{ FdG } & \multicolumn{3}{|c|}{ Afgestudeerden van de } & \multirow[b]{2}{*}{ Totaal } \\
\hline & & FdGW & FdR & FdEW & \\
\hline VWO & 90 & 81 & 83 & 79 & 84 \\
\hline HBO & 9 & 16 & 12 & 21 & 13 \\
\hline wo & -- & 2 & 2 & -- & 1 \\
\hline Andere* & 1 & 2 & 2 & -- & 2 \\
\hline Totaal n (=100\%) & 330 & 385 & 343 & 42 & 1100 \\
\hline
\end{tabular}

* Bijvoorbeeld colloquium doctum, buitenlandse vooropleiding. 
Tabel 4. Betaalde werkervaring voór of tijdens de studie aan de RL (in\%); meerdere antwoorden mogelijk.

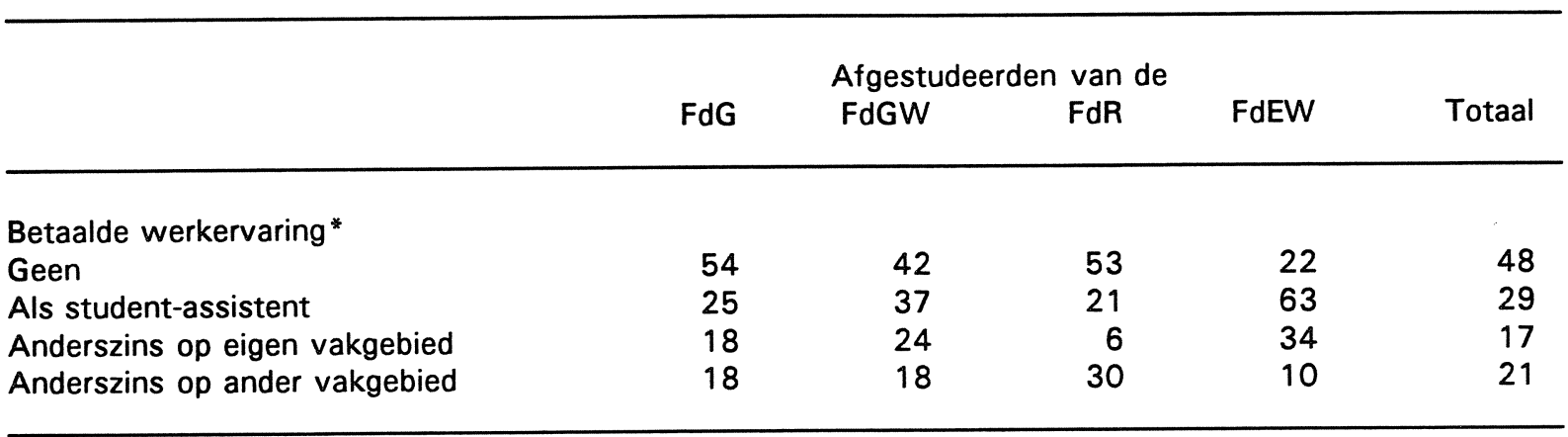

* Vakantie-/weekendwerk niet inbegrepen

Tabel 5. Verschuivingen in het aandeel van betaald werkenden tijdens het eerste jaar na afstuderen, naar jaar van afstuderen (in \%)

\begin{tabular}{lccccc}
\hline & \multicolumn{7}{c}{$\begin{array}{l}\text { Jaar van afstuderen } \\
\text { Periode na afstuderen }\end{array}$} & 1986 & 1987 & 1988 & 1989 & Totaal \\
\hline $\begin{array}{l}\text { Eerste maand na afstuderen/ } \\
\text { kwartaal van afstuderen }\end{array}$ & 46 & 40 & 33 & 36 & 38 \\
$\begin{array}{l}\text { Derde maand na afstuderen/ } \\
\text { eerste kwartaal na afstuderen }\end{array}$ & 62 & 55 & 41 & 47 & 49 \\
$\begin{array}{l}\text { Zesde maand na afstuderen/ } \\
\text { tweede kwartaal na afstuderen }\end{array}$ & 69 & 61 & 58 & 56 & 60 \\
$\begin{array}{l}\text { Twaalfde maand na afstuderen/ } \\
\text { vierde kwartaal na afstuderen }\end{array}$ & 77 & 73 & 66 & 70 & 71 \\
\hline
\end{tabular}

\section{Toelichting}

Bij degenen die vóór juli 1988 afstudeerden zijn de belangrijkste bezigheden in de periode tussen het moment van afstuderen en dat van enquêteren met behulp van een in kwartalen verdeelde tijdbalk gemeten. Bij degenen die nadien zijn afgestudeerd is met behulp van een in maanden verdeelde tijdbalk gemeten. De verschillen tussen de afstudeerjaren zijn bij iedere maand/kwartaal significant. 
$-111-$

Tabel 6. Grootte van de werkorganisatie, naar faculteit (in \%)

\begin{tabular}{|c|c|c|c|c|c|}
\hline \multirow[b]{2}{*}{ Aantal personeelsleden } & \multirow[b]{2}{*}{ FdG } & \multicolumn{3}{|c|}{ Afgestudeerden van de } & \multirow[b]{2}{*}{ Totaal } \\
\hline & & FdGW & $\mathrm{FdR}$ & FdEW & \\
\hline$<10$ & 20 & 6 & 20 & -- & 14 \\
\hline $10-49$ & 15 & 23 & 18 & 8 & 18 \\
\hline $50-99$ & 6 & 11 & 11 & 13 & 9 \\
\hline$>99$ & 60 & 61 & 51 & 79 & 59 \\
\hline Totaal $n(=100 \%)$ & 298 & 329 & 256 & 38 & 921 \\
\hline
\end{tabular}

Tabel 7. Regio waarbinnen de huidige functie wordt uitgeoefend (in \%)

\begin{tabular}{|c|c|c|c|c|c|}
\hline \multirow[b]{2}{*}{ Regio } & \multirow[b]{2}{*}{ FdG } & \multicolumn{2}{|c|}{ Afgestudeerden van de } & \multirow[b]{2}{*}{ FdEW } & \multirow[b]{2}{*}{ Totaal } \\
\hline & & FdGW & FdR & & \\
\hline Maastricht & 25 & 22 & 32 & 35 & 26 \\
\hline Overig Zuid-Limburg & 21 & 14 & 29 & 19 & 21 \\
\hline Overig Limburg & 9 & 5 & 9 & 3 & 8 \\
\hline Andere provincies & 34 & 55 & 29 & 43 & 41 \\
\hline Buitenland & 11 & 3 & 2 & & 5 \\
\hline Totaal n (=100\%) & 293 & 327 & 245 & 37 & 902 \\
\hline
\end{tabular}

Tabel 8. De beroepsgroepen- en branchespreiding van RL-studie/afstudeerrichtingen, verdeeld naar geslacht

\begin{tabular}{lcccc}
\hline \multicolumn{2}{c}{ SOB } & \multicolumn{2}{c}{ SOBR } \\
Richting & man & vrouw & man & vrouw \\
\hline \multirow{2}{*}{ Geneeskunde } & 0,27 & 0,26 & 0,75 & 0,80 \\
BB & 0,91 & 0,88 & 0,86 & 0,88 \\
GVO & 0,78 & 0,68 & 0,76 & 0,78 \\
VW & 0,84 & 0,89 & 0,80 & 0,86 \\
Nederlands recht & 0,80 & 0,76 & 0,89 & 0,87 \\
\hline
\end{tabular}


Tabel 9A. Basisartsen naar huidig beroep (in \%)

Huidig beroep

Huisarts 14

Arts-specialist

Arts-assistent

School-, bedrijfs-, verzekerings-, consultatiebureau-arts e.d. (geen specialist)

Sociaal-geneeskundige (bijv. medisch adviseur)

Medisch-wetenschappelijk onderzoeker

Andere beroepen*

Totaal $\mathrm{n}(=100 \%)$

* Bijvoorbeeld docent, biochemicus, medisch-beleidsmedewerker.

Tabel 9B. Bedrijfssubgroepen waarbinnen tenminste $5 \%$ van de betaald werkende basisartsen werken (in \%)

Bedrijfssubgroep

Algemene, niet-academische ziekenhuizen

Academische algemene ziekenhuizen

Gespecialiseerde ziekenhuizen (excl. psychiatrische)

Wettelijke sociale verzekeringsorganen 
Tabel 10A. Oud-studenten BB naar huidig beroep (in \%)

Huidig beroep

Beleidsmedewerker 32

Bedrijfsorganisatiedeskundige

Administratieve automatiseringsdeskundige

Econoom

Sociaal-wetenschappelijk onderzoeker

Beroepsgroep 'hogere leidinggevende functies'

Beroepssector 'administratieve functies'

Beroepsklasse 'docenten'

Andere beroepen*

Totaal $n(=100 \%)$

* Bijvoorbeeld staffunctionaris verpleging, personeelsfunctionaris.

Tabel 10B. Bedrijfssubgroepen waarbinnen tenminste $5 \%$ van de betaald werkende oud-studenten BB werken (in \%)

Bedrijfssubgroep

Samenwerkings- en adviesorganen op het gebied van de gezondheidszorg $\quad 15$

Algemene, niet-academische ziekenhuizen 
Tabel 11A. Oud-studenten GVO naar huidig beroep (in\%)

Huidig beroep

Medisch-maatschappelijk werker 41

Sociaal-wetenschappelijk onderzoeker

Beleidsmedewerker

Beroepsklasse 'docenten'

Gemeentelijk maatschappelijk werker

Andere beroepen*

Totaal $\mathrm{n}(=100 \%)$

* Bijvoorbeeld (para)medisch-wetenschappelijk onderzoeker, artsenbezoeker.

Tabel 11B. Bedrijfssubgroepen waarbinnen tenminste $5 \%$ van de betaald werkende oud-studenten GVO werken (in \%)

Bedrijfssubgroep

Universiteiten

Medische en verpleegkundige diensten, zoals GGD's

22

Samenwerkings- en adviesorganen op het gebied van de gezondheidszorg

Algemene, niet-academische ziekenhuizen 
Tabel 12A. Oud-studenten VW naar huidig beroep (in \%)

Huidig beroep

Staffunctionaris verpleging 20

Docent (para)medische vakken

Sociaal-wetenschappelijk onderzoeker

(Para)medisch-wetenschappelijk onderzoeker

Medisch-beleidsmedewerker

Artsenbezoeker

Hoofdverpleegkundige

Verpleegkundige

Medisch-maatschappelijk werker

Andere beroepen*

Totaal $\mathrm{n}(=100 \%)$

* Bijvoorbeeld arbeidskundige, personeelsfunctionaris.

Tabel 12B. Bedrijfssubgroepen waarbinnen tenminste $5 \%$ van de betaald werkende oud-studenten VW werken (in \%)

Bedrijfssubgroep

Algemene, niet-academische ziekenhuizen

Universiteiten

HBO-instellingen 
Tabel 13A. Juristen naar huidig beroep (in \%)

Huidig beroep

Advocaat 18

Juridisch (beleids)medewerker

Juridisch adviseur

Bedrijfsjurist

Juridisch wetenschappelijk onderzoeker, bijv. AIO

Juridisch wetenschappelijk medewerker

Jurist, niet eerder genoemd

Hoofd afdeling juridische zaken

Beroepsklasse 'docenten'

Beroepssector 'administratieve functies'

$\begin{array}{lr}\text { Andere beroepen* } & 13\end{array}$

Totaal n (=100\%) 256

* Bijvoorbeeld bedrijfsorganisatiedeskundige, belastingconsulent, bankemployé.

Tabel 13B. Bedrijfssubgroepen waarbinnen tenminste $5 \%$ van de betaald werkende juristen werken (in \%) 
Tabel 14A. Economen naar huidig beroep (in \%)

Huidig beroep

(Bedrijfs)econoom, economisch onderzoeker

Economisch adviseur

Marketing-specialist

Accountant

Assistent-accountant

Docent economie

Andere beroepen*

Totaal n (=100\%)

* Bijvoorbeeld bedrijfsorganisatiedeskundige, bankemployé

Tabel 14B. Bedrijfssectoren waarbinnen tenminste $5 \%$ van de betaald werkende economen werken (in \%)

Bedrijfssector 
Tabel 15. Mate van leidinggeven in huidige functie, naar faculteit (in \%)

Afgestudeerden van de

Aantal personen waaraan

FdG

FdGW

FdR

FdEW

Totaal

leiding wordt gegeven

\begin{tabular}{lrrrrr}
\hline Geen & 65 & 77 & 73 & 74 & 72 \\
$1-4$ & 22 & 14 & 20 & 13 & 19 \\
$5-9$ & 6 & 3 & 2 & 3 & 4 \\
$>9$ & 6 & 6 & 5 & 11 & 6 \\
Totaal $n(=100 \%)$ & 299 & 329 & 258 & 38 & 924 \\
\hline
\end{tabular}

Tabel 16. Bruto maandinkomen (bij een volledige werkweek) in de huidige betaalde functie, naar faculteit en naar geslacht (in \%)

\begin{tabular}{|c|c|c|c|c|c|c|c|}
\hline \multirow[b]{2}{*}{ Inkomen } & \multirow[b]{2}{*}{ FdG } & \multicolumn{3}{|c|}{ Afgestudeerden van de } & \multirow[b]{2}{*}{ totaal } & \multirow[b]{2}{*}{ man } & \multirow[b]{2}{*}{ vrouw } \\
\hline & & FdGW & FdR & FdEW & & & \\
\hline$<f 2.000$ & 5 & 6 & 5 & 14 & 6 & 5 & 7 \\
\hline$f 2.000-f 2.500$ & 7 & 9 & 9 & 3 & 8 & 9 & 8 \\
\hline$f 2.500-f 3.000$ & 8 & 8 & 16 & -- & 10 & 8 & 11 \\
\hline$f 3.000-f 3.750$ & 11 & 38 & 37 & 42 & 29 & 23 & 33 \\
\hline$f 3.750-f 5.000$ & 52 & 33 & 26 & 39 & 38 & 38 & 37 \\
\hline$>f 5.000$ & 18 & 6 & 7 & 3 & 10 & 16 & 5 \\
\hline Totaal $n(=100 \%)$ & 295 & 326 & 238 & 36 & 895 & 386 & 509 \\
\hline
\end{tabular}

Tabel 17. Niveau later gevolgd onderwijs, naar faculteit (in \%)

\begin{tabular}{|c|c|c|c|c|c|}
\hline \multirow[b]{2}{*}{ Niveau } & \multirow[b]{2}{*}{ FdG } & \multicolumn{3}{|c|}{ Afgestudeerden van de } & \multirow[b]{2}{*}{ Totaal } \\
\hline & & FdGW & FdR & FdEW & \\
\hline Geen later onderwijs & 31 & 36 & 30 & 17 & 32 \\
\hline Lager dan wo & 5 & 17 & 11 & 2 & 11 \\
\hline WO $1 \mathrm{e}$ fase & 3 & 14 & 18 & 5 & 12 \\
\hline WO 2 e fase & 18 & 7 & 4 & 21 & 10 \\
\hline Post-doctorale (beroeps)opleidingen & 21 & 9 & 19 & 45 & 17 \\
\hline Post-academische cursussen & 18 & 12 & 14 & 2 & 14 \\
\hline Niveau onbekend & 5 & 5 & 5 & 7 & 5 \\
\hline Totaal $n(=100 \%)$ & 325 & 382 & 339 & 42 & 1088 \\
\hline
\end{tabular}


Tabel 18. Later gevolgd onderwijs naar richting (in \%)

\begin{tabular}{|c|c|c|c|c|c|c|}
\hline \multirow[b]{2}{*}{ Richting later onderwijs } & \multirow[b]{2}{*}{ FdG } & \multirow[b]{2}{*}{ BB } & \multicolumn{2}{|c|}{ Oud-studenten } & \multirow[b]{2}{*}{ FdR } & \multirow[b]{2}{*}{ FdEW } \\
\hline & & & GVO & VW & & \\
\hline \multicolumn{7}{|l|}{ MEDISCH } \\
\hline Geneeskunde & 82 & 4 & 11 & 2 & 0 & 0 \\
\hline Verpleging & 1 & 1 & 4 & 32 & 0 & 0 \\
\hline Therapie & 1 & 0 & 2 & 4 & 0 & 0 \\
\hline Medisch-fysische techniek & 1 & 0 & 0 & 0 & 0 & 0 \\
\hline Beleid/management gezondheidszorg & 1 & 8 & 11 & 9 & 0 & 0 \\
\hline Gezondheidswetenschappen & 1 & 1 & 15 & 2 & 0 & 0 \\
\hline \multicolumn{7}{|l|}{$\begin{array}{l}\text { ECONOMISCH/ADMINISTRATIEF/ } \\
\text { COMMERCIEEL }\end{array}$} \\
\hline Economie & 0 & 11 & 0 & 2 & 3 & 40 \\
\hline Bedrijfskunde/-management & 0 & 19 & 11 & 17 & 8 & 11 \\
\hline Administratie & 2 & 23 & 2 & 9 & 1 & 29 \\
\hline Commercieel & 1 & 15 & 7 & 6 & 7 & 9 \\
\hline Bedrijfstechniek & 0 & 1 & 2 & 0 & 0 & 0 \\
\hline \multicolumn{7}{|l|}{ JURIDISCH } \\
\hline Recht & 0 & 8 & 4 & 2 & 58 & 0 \\
\hline Openbaar bestuur & 1 & 1 & 0 & 0 & 5 & 0 \\
\hline Belastingen & 0 & 0 & 0 & 0 & 4 & 0 \\
\hline SOCIAAL-CULTUREEL & 2 & 2 & 11 & 2 & 4 & 0 \\
\hline OVERIG* & 7 & 6 & 20 & 13 & 10 & 11 \\
\hline Totaal n (= $100 \%)$ & 210 & 84 & 55 & 47 & 238 & 35 \\
\hline
\end{tabular}

* Bijvoorbeeld opleidingen voor onderwijzend personeel, linguïstiek, wiskunde.

Tabel 19. Duur van de aanstelling in loondienst, naar faculteit (in \%)

\begin{tabular}{lccccr}
\hline & \multicolumn{5}{c}{ Afgestudeerden van de } \\
Tijdsduur aanstelling & FdG & FdGW & FdR & FdEW & Totaal \\
\hline \multirow{2}{*}{13 maanden } & 35 & 29 & 37 & 14 & 32 \\
$13-24$ maanden & 36 & 23 & 17 & 11 & 25 \\
$25-60$ maanden & 17 & 25 & 20 & 17 & 21 \\
vast dienstverband & 12 & 24 & 27 & 58 & 22 \\
Totaal $\mathrm{n}$ (=100\%) & 274 & 318 & 234 & 36 & 862 \\
\hline
\end{tabular}


$-120-$

Tabel 20. Aantal arbeidsuren per week in de huidige betaalde functie, naar faculteit (in \%) en geslacht (in gemiddelden)

\begin{tabular}{|c|c|c|c|c|c|}
\hline \multirow[b]{2}{*}{ Aantal uren } & \multirow[b]{2}{*}{ FdG } & \multicolumn{2}{|c|}{ Afgestudeerden van de } & \multirow[b]{2}{*}{ FdEW } & \multirow[b]{2}{*}{ Totaal } \\
\hline & & FdGW & FdR & & \\
\hline$<21$ & 6 & 8 & 9 & -- & 7 \\
\hline $21-35$ & 11 & 19 & 5 & 13 & 12 \\
\hline $36-39$ & 11 & 25 & 21 & 11 & 19 \\
\hline 40 & 26 & 44 & 52 & 68 & 41 \\
\hline$>40$ & 47 & 5 & 13 & 8 & 21 \\
\hline Totaal n (=100\%) & 299 & 331 & 254 & 38 & 922 \\
\hline \multicolumn{6}{|c|}{ Gemiddelde aantal uren: } \\
\hline totaal & 45,5 & 36,3 & 38,3 & 39,6 & 40,0 \\
\hline - man & 49,2 & 38,7 & 39,7 & 39,8 & 43,2 \\
\hline - vrouw & 41,3 & 35,6 & 36,8 & 39,0 & 37,5 \\
\hline
\end{tabular}




\section{BIJLAGE 2. SCHATTING VAN DE DUUR VAN DE INTREDEWERKLOOSHEID}

\section{Het gebruikte model}

In de afgelopen jaren is in ons land een aantal studies verricht waarin werd geprobeerd een schatting te maken van de werkloosheidsduren van schoolverlaters. Er zal een keuze worden gemaakt uit de modellen die in deze studies werden gebruikt.

Een eerste mogelijkheid is het schatten van een verklarend duurmodel. Hierin worden waargenomen werkloosheidsduren verklaard aan de hand van persoonlijke kenmerken van individuen en kenmerken van zijn of haar omgeving, zoals de toestand van de lokale arbeidsmarkt. Er wordt daarbij verondersteld dat deze kenmerken een verschuiving ten opzichte van een basisverdeling (de 'base-line') van de werkloosheidsduur bewerkstelligen. Daarbij dient men a priori een expliciete keuze te maken over de vorm van deze basisverdeling. Bij het gebruik van een dergelijk model is het noodzakelijk dat er voldoende verklarende variabelen worden opgenomen, vanwege mogelijke 'unobserved heterogenity' (zie Lancaster 1979), of dat deze niet-geobserveerde heterogeniteit expliciet wordt gemodelleerd. Niet-geobserveerde heterogeniteit betekent dat het gedeelte van de steekproef dat na verloop van tijd overblijft in het werklozenbestand relatief slechter is volgens een niet-waargenomen kenmerk. Aangezien dit kenmerk niet is opgenomen als verklarende variabele, zal het effect - ten onrechte - worden toegeschreven aan andere variabelen of aan het verloop in de tijd van de basisverdeling. Verwaarlozing van dit verschijnsel kan dus niet alleen leiden tot onjuiste waarden voor de parameters, maar ook en vooral tot een verkeerde inschatting van de tijdafhankelijkheid van de conditionele uittredekans uit de werkloosheid. Het lijkt dan alsof personen die langer werkloos zijn ceteris paribus een steeds kleinere conditionele kans hebben om uit de werkloosheid te ontsnappen, terwijl dit in feite is toe te schrijven aan een niet waargenomen persoonlijk kenmerk.

Een andere mogelijke aanpak is het schatten van de verwachte werkloosheidsduur van schoolverlaters met behulp van een semi-parametrische schattingsmethode. Hierbij wordt geen expliciete keuze wordt gemaakt voor de basisverdeling van conditionele ontsnappingskans, de 'hazard' ${ }^{1}$, maar wel voor de invloed van de verklarende variabelen op de basisverdeling. Kennis

1. De 'hazard' is de conditionele uittredekans. Dit wil zeggen de kans dat, gegeven het feit dat het individu tot tijdstip $t$ werkloos is geweest, het individu in de komende periode $(t+$ $\mathrm{dt}$ ) uit het werklozenbestand zal uitstromen. De term 'hazard' verwijst naar de oorspronkelijke formulering van de theorie uit de medische statistiek, waarin het gaat om de kans dat, gegeven het feit dat de patiënt tot tijdstip $t$ in leven is gebleven, de patiënt in de periode $t+d t z a l$ overlijden. 
over het precieze verloop in de tijd van de verdeling van de hazard is voor onze doeleinden ook minder relevant dan kennis over de invloed van de exogenen. Dit model wordt geschat op basis van een partiële likelihood, namelijk de likelihood ten opzichte van een willekeurige baseline hazard. Dit is het 'proportional hazards' model (Cox en Oakes 1984).

Een voorbeeld van een dergelijk proportional hazards model is de studie van Meesters en Huson (1990). Zij schatten een verklarend model voor de startwerkloosheid van schoolverlaters. Zij gebruikten hiervoor een CBS-dataset die uitgebreide informatie bevat over achtergrondkenmerken van schoolverlaters uit de periode 1977-1987. Deze data werden per schooltype gegroepeerd, zodat er per groep ruim voldoende waarnemingen waren om een uitgebreid model te specificeren. Voor de duur-analyse werd het proportional hazards model van Cox (zie Kalbfleisch en Prentice 1980) gebruikt.

\section{Schattingsresultaten}

\begin{tabular}{lrrrrr}
\hline Variable & Mean & Standard Deviation & Coefficient & Coeff./S.E. & Exp(coeff.) \\
\hline & & & & & \\
leeftijd & 29.3517 & 4.8415 & -0.1159 & -2.3657 & 0.8905 \\
leeft2 & 884.9371 & 346.4437 & 0.0015 & 2.2602 & 1.0015 \\
werk1 & 0.5334 & 0.4991 & 0.1464 & 1.0821 & 1.1576 \\
werk2 & 0.2986 & 0.4579 & 0.1569 & 1.4540 & 1.1698 \\
werk3 & 0.1758 & 0.3809 & 0.1337 & 1.1501 & 1.1430 \\
werk4 & 0.2210 & 0.4151 & 0.0658 & 0.5586 & 1.0680 \\
bestuur & 0.3527 & 0.4780 & 0.1485 & 2.1744 & 1.1601 \\
geslacht & 0.4126 & 0.4925 & -0.0435 & -0.6154 & 0.9574 \\
vooropl & 0.1493 & 0.3566 & 0.2271 & 2.2217 & 1.2550 \\
overig GW & 0.0884 & 0.2840 & -0.3013 & -2.2953 & 0.7399 \\
BB & 0.1228 & 0.3284 & -0.3320 & -2.9165 & 0.7175 \\
GVO & 0.0786 & 0.2692 & -0.5315 & -3.8498 & 0.5877 \\
VW & 0.0707 & 0.2565 & -0.0552 & -0.3970 & 0.9463 \\
economie & 0.0413 & 0.1990 & 0.0370 & 0.2077 & 1.0377 \\
rechten & 0.3094 & 0.4625 & -0.1700 & -1.9083 & 0.8437 \\
1987 & 0.2033 & 0.4027 & -0.0582 & -0.5388 & 0.9435 \\
1988 & 0.3143 & 0.4645 & -0.0619 & -0.5972 & 0.9400 \\
1989 & 0.3251 & 0.4687 & 0.1759 & 1.6068 & 1.1923 \\
\hline
\end{tabular}

LOG LIKELIHOOD $=-6131.3131$

GLOBAL CHI-SOUARE $=69.09$ D.F. $=18$ P-VALUE $=0.0000$

De schattingsresultaten zijn in bovenstaande tabel weergegeven. De onderscheiden variabelen zijn dummy variabelen, met uitzondering van leeftijd en leeftijd in het kwadraat (leeft 2). De dummies hebben achtereenvolgens betrekking op betaalde werkervaring (werk 1); studentassistentenschap (werk 2); werkervaring in eigen vakgebied (werk 3); werkervaring 
buiten eigen vakgebied (werk 4); bestuurlijke ervaring (bestuur); mannelijk geslacht (geslacht); vooropleiding op HBO- of WO niveau (vooropl); gezondheidswetenschappen richting BGK, GGK. BW of FT (overig GW); gezondheidswetenschappen richting BB (BB); gezondheidswetenschappen richting GVO (GVO); gezondheidswetenschappen richting VW (VW); studierichting economie (economie); studierichting rechten (rechten); afstudeerjaar (1987, 1988 of 1989). Voor een precieze omschrijving en codering van deze variabelen wordt verwezen naar bijlage 3.

De in de tabel weergegeven parameters geven de invloed van de desbetreffende variabele op de hazard weer. Een positief teken betekent dus een grotere ontsnappingskans en dus c.p. een kortere werkloosheidsduur. De getallen in de voorlaatste kolom zijn te interpreteren als $t$ waarden. Een waarde $>1.96$ duidt op een significant van nul verschillende parameterschatting. 


$$
\ldots
$$




\title{
BIJLAGE 3. DUMMY-VARIABELEN
}

\author{
Geslacht \\ 0 = vrouw \\ $1=\operatorname{man}$
}

\section{Vooropl}

0 = beschikt over ten hoogste VWO-diploma voor aanvang van RL-studie

1 = beschikt over HBO- of WO-diploma voor aanvang van RL-studie

\section{Werk1}

$0=$ geen betaalde werkervaring voor afstuderen

$1=$ wel betaalde werkervaring voor afstuderen

\section{Werk2}

0 = geen student-assistentschap verricht

$1=$ wel student-assistentschap verricht

\section{Werk3}

$0=$ geen betaalde werkervaring binnen 'eigen' vakgebied voor afstuderen

$1=$ wel betaalde werkervaring binnen 'eigen' vakgebied voor afstuderen

Werk4

$0=$ geen betaalde werkervaring buiten 'eigen' vakgebied voor afstuderen

$1=$ wel betaalde werkervaring buiten 'eigen' vakgebied voor afstuderen

Bestuur

$0=$ geen bestuurlijke ervaring voor afstuderen

1 = wel bestuurlijke ervaring voor afstuderen

\section{Geneeskunde}

$0=$ in andere studie dan geneeskunde afgestudeerd

$1=$ in geneeskunde afgestudeerd

Rechten

$0=$ in andere studie dan Nederlands recht afgestudeerd

$1=$ in Nederlands recht afgestudeerd 


\section{Economie}

$0=$ in andere studie dan economie afgestudeerd

$1=$ in economie afgestudeerd

BB

$0=$ in andere studie dan beleid en beheer afgestudeerd

$1=$ in beleid en beheer afgestudeerd

GVO

$0=$ in andere richting dan gezondheidsvoorlichting en -opvoeding afgestudeerd

$1=$ in gezondheidsvoorlichting en -opvoeding afgestudeerd

VW

$0=$ in andere richting dan verplegingswetenschap afgestudeerd

$1=$ in verplegingswetenschap afgestudeerd

Overig GW

$0=$ in andere richtingen dan BGK, GGK, BW of FT afgestudeerd

1 = wel in BGK, GGK, BW of FT afgestudeerd

1987

$0=$ in ander jaar dan 1987 afgestudeerd

$1=$ in 1987 afgestudeerd

\section{8}

$0=$ in ander jaar dan 1988 afgestudeerd

$1=$ in 1988 afgestudeerd

\section{9}

$0=$ in ander jaar dan 1989 afgestudeerd

$1=$ in 1989 afgestudeerd

Baanmobiliteit

$0=$ niet van werkgever veranderd

$1=$ wel van werkgever veranderd. 


\section{Branche}

$0=$ overheidssector

1 = profit sector

\section{Bedrijfsomvang}

$0=<100$ werknemers

$1=>99$ werknemers

\section{Niveau-eis}

0 = functie waarvoor een opleiding op WO-niveau niet is vereist

1 = functie waarvoor een opleiding op WO-niveau wel is vereist

\section{Leiding}

$0=$ geen leidinggevende functie

$1=$ wel leidinggevende functie

\section{Combi}

$0=$ niet 'on the job' leren

$1=$ wel 'on the job' leren

\section{Baanzekerheid}

$0=$ aanstelling in tijdelijke dienst $(<61$ maanden $)$

$1=$ aanstelling in vaste dienst ( $>60$ maanden)

\section{Werktijdfactor}

$0=$ part-time baan ( $<35$ uur per week)

1 = full-time baan ( $>34$ uur per week)

\section{Baanstabiliteit}

$0=$ geen tijdelijke part-time baan

$1=$ wel tijdelijke part-time baan

Potentiële baanmobiliteit

$0=$ betaald werkenden die niet op zoek zijn naar een andere baan

$1=$ betaald werkenden die wel op zoek zijn naar een andere baan 



\section{VRAGENLIJST}

De loopbaan van economen die in 1989 aan de RL zijn afgestudeerd november 1990

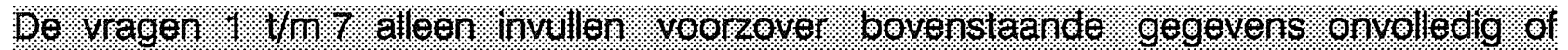
onust zill voorgedrikt.

1. Naam + voorletters

(gehuwde vrouwen dienen hier hun meisjesnaam te vermelden)

2. Straatnaam en huisnummer :

3. Postcode en woonplaats

4. Land

5. Telefoon

6. Geboortejaar

: 19

7. Geslacht 


\section{Instructies voor het invullen van de volgende vragen!}

$U$ wordt verzocht om het getal te omcirkelen dat hoort bij het antwoord dat voor $u$ van toepassing is. Er is steeds maar één antwoord mogelijk, tenzij anders is aangegeven. Fouten kunt $u$ corrigeren met een kruis door het foute getal en een cirkel om het juiste getal. 
8. Hoogste met diploma afgesloten opleiding vóór uw afstuderen aan de RL als econoom.

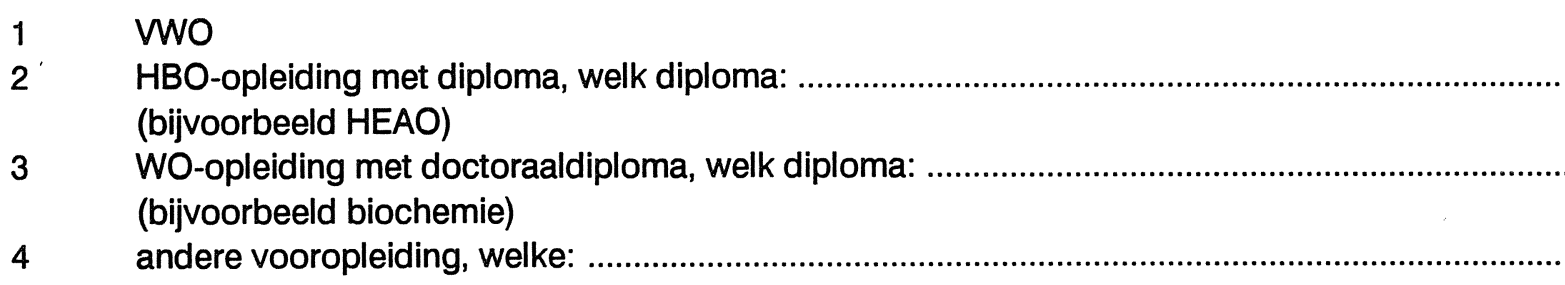

9. Studie-/afstudeerrichting(en) aan de RL waarvoor $\mathrm{u}$ uw doctoraaldiploma heeft behaald. (meerdere antwoorden zijn mogelijk)

\begin{tabular}{|c|c|c|c|}
\hline & Studie-/afstudeerrichting & wannee & doctoraaldiploma behaald? \\
\hline & & jaar & maand \\
\hline 1 & geneeskunde & $19 \ldots \ldots$. & 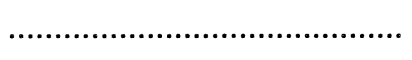 \\
\hline 2 & gezondheidswet. / BB & $19 \ldots \ldots$. & \\
\hline 3 & gezondheidswet. / BW & $19 \ldots \ldots .$. & 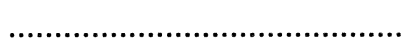 \\
\hline 4 & gezondheidswet. / BGK & $19 \ldots \ldots$. & 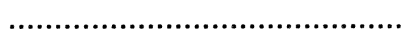 \\
\hline 5 & gezondheidswet. / FT & $19 \ldots \ldots$. & 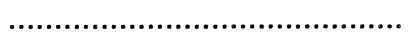 \\
\hline 6 & gezondheidswet. / GGK & $19 \ldots \ldots .$. & 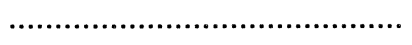 \\
\hline 7 & gezondheidswet. / GVO & $19 \ldots \ldots$. & 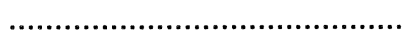 \\
\hline 8 & gezondheidswet. / WW & $19 \ldots \ldots$. & $\ldots$ \\
\hline 9 & nederlands recht & $19 \ldots \ldots$. & 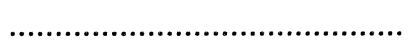 \\
\hline 10 & 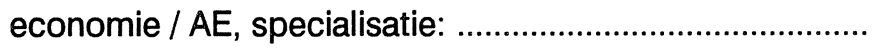 & $19 \ldots \ldots$. & \\
\hline 11 & 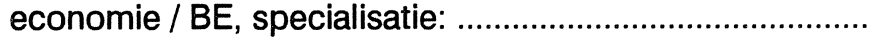 & $19 \ldots \ldots .$. & 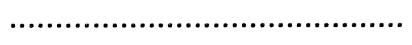 \\
\hline 12 & economie / KE, specialisatie: & $19 \ldots \ldots .$. & (1) \\
\hline 13 & 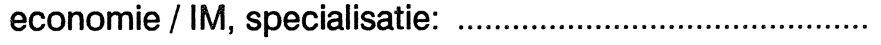 & $19 \ldots \ldots .$. & (1) \\
\hline 14 & economie / vrij doctoraal & $19 \ldots \ldots$. & (2) \\
\hline
\end{tabular}

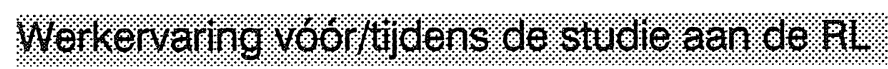

10. Werkervaring vóór/tijdens uw studie economie aan de RL. Het gaat hier om betaald werk. (meerdere antwoorden zijn mogelijk)

1 geen betaalde werkervaring of uitsluitend vakantiewerk c.q. weekendwerk

2 als student-assistent betaald werk verricht

3 anderszins betaald werk verricht (op economisch gebied)

$4 \quad$ anderszins betaald werk verricht (op niet-economisch gebied)

11. Heeft u vóór/tijdens uw studie economie aan de RL bestuurlijke ervaring opgedaan?

1 ja; in welk verband (bijv. faculteitsraad):

2 nee 
12. Omcirkel de maand van het jaar 1989 waarin $u$ het doctoraaldiploma economie heeft ontvangen én de maand waarin u de vragenlijst invult. Noteer vervolgens achter iedere tussenliggende maand het codenummer dat het beste past bij uw dagelijkse bezigheden in de desbetreffende maand. $U$ kunt de bezigheden met behulp van onderstaande codenummers aangeven.

1 = betaald werk; $\mathrm{u}$ heeft een werkkring, bedrijf of praktijk:

. werkt in loondienst

. werkt voor eigen rekening of risico

. werkt als gezinslid mee in het bedrijf van echtgenoot/ouders

. werkt op sociale werkplaats

. in opleiding bij een bedrijf of instelling maar met loon of salaris (bijv. AIO)

. stagiair met loon of salaris

2 = dienstplichtig militair (eerste oefening) of vervangende dienstplicht

$3=$ full-time onderwijs

$4=$ huisvrouw/huisman

$5=$ arbeidsongeschikt, geheel of gedeeltelijk

$6=$ onbetaald werk met behoud van uitkering

$7=$ werkloos, zonder onbetaald werk

$8=$ andere situatie, namelijk:

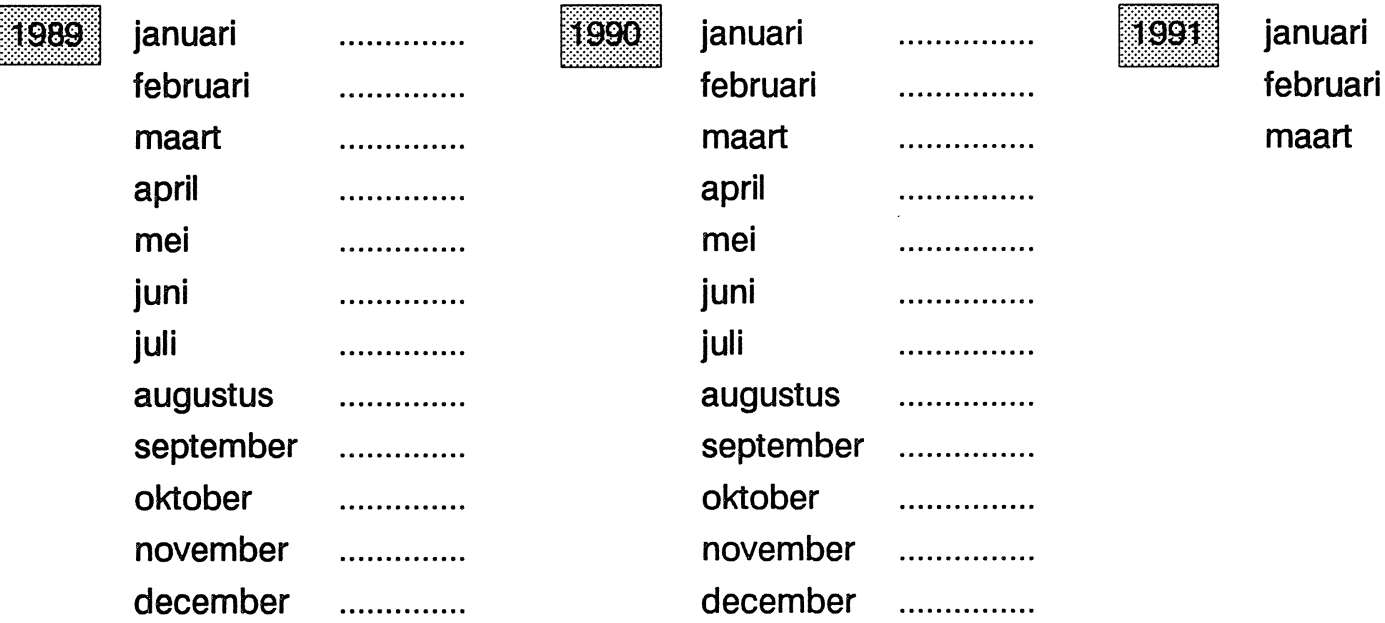

13. Deze vraag betreft uw huidige situatie. Als u onderstaande mogelijkheden bekijkt, waartoe rekent $u$ zich dan? Omcirkel het codenummer dat het beste past bij uw huidige situatie.

Er is slechts één antwoord mogelijk.

1 betaald werk; u heeft een werkkring, bedrijf of praktijk (zie vraag 12)

2 dienstplichtig militair (eerste oefening) of vervangende dienstplicht

3 full-time onderwijs

4 huisvrouw/huisman

5 arbeidsongeschikt, geheel of gedeeltelijk

$6 \quad$ onbetaald werk met behoud van uitkering

7 werkloos, zonder onbetaald werk

8 andere situatie, namelijk:

$\mathrm{Bij}$ codenummer 1 gaat $\mathrm{u}$ verder met vraag 15

Bij de overige codenummers gaat $u$ verder met vraag 14 
14. Vervult u naast uw huidige bezigheden, die u bij vraag 13 heeft omcirkeld, ook nog betaald werk?

$\begin{array}{lll}1 & \text { ja } & \text { ga verder met vraag } 15 \\ 2 & \text { nee } & \text { ga verder met vraag } 32\end{array}$

\section{Findige baan}

Indien u meer dan één baan heeft, hebben de vragen 16 tot en met 31 betrekking op de baan met de meeste arbeidsuren

15. Bent $\mathrm{u}$ na het afstuderen aan de $\mathrm{RL}$ al eens van werkgever veranderd?

$\begin{array}{ll}1 & \text { ja, hoe vaak } \\ 2 & \text { nee }\end{array}$

16. Bent $\mathrm{u}$ bij uw huidige werkgever al eens van functie veranderd?

(b.v. promotie, overplaatsing of substantiële verandering van de inhoud van de werkzaamheden)

1 ja

2 nee

17. Op welke wijze heeft $\mathrm{u} u$ w huidige functie verworven? Omcirkel het juiste codenummer. Er is maar één antwoord mogelijk.

1 sollicitatie op advertentie

2 via familie, vrienden

3 via medewerkers Faculteit der Economische Wetenschappen

4 via studentassistentschap

5 via stagecontacten

6 via het arbeidsbureau

7 via een uitzendbureau

8 via een wervingsorganisatie (head-hunting)

9 via vrijwilligerswerk

10 zelf gevraagd bij werkgever (open sollicitatie)

11 zelf advertentie geplaatst

12 werd benaderd door werkgever

13 zelf bedrijf/praktijk opgezet

14 andere wijze

18. In welk dienstverband bent $u$ thans werkzaam?

1 in loondienst

ga verder met vraag 19

2 als zelfstandige voor eigen rekening of risico

ga verder met vraag 20

19. Noteer het totaal aantal maanden waarop uw formele aanstelling in loondienst betrekking heeft. Diegenen die een aanstelling hebben voor meer dan 5 jaar noteren nummer 99.

totaal aantal maanden 
20. Combineert u betaald werken met verder studeren binnen uw huidige functie?

1 ja, als assistent in opleiding (AIO) of onderzoeker in opleiding (OIO)

2 ja, anderszins namelijk:

3 nee

21. Hoeveel uren per week werkt u gewoonlijk? Noteer het (gemiddelde) aantal arbeidsuren. Laat de uren door overwerk en voor nevenfuncties buiten beschouwing.

gemiddeld: uren per week

22. Wat is de naam van uw huidige functie? (eventueel nader omschrijven)

naam functie:

23. Op het inlegvel vindt $u$ een schema van beroepsgroepen, met de bijbehorende codenummers, zoals die door het CBS worden gehanteerd. Noteer hieronder het codenummer dat correspondeert met uw werkzaamheden in uw huidige functie.

codenummer beroepsgroep:

24. Bestond de functie al voordat $u$ deze zelf ging vervullen?

$\begin{array}{ll}1 & \text { ja } \\ 2 & \text { nee } \\ 3 & \text { weet niet }\end{array}$

25. Kunt $u$ aangeven wat de minimale opleidingsvereisten voor uw huidige functie zijn?

$\begin{array}{ll}1 & \text { geen opleidingsvereiste } \\ 2 & \text { lager dan HBO-opleiding } \\ 3 & \text { tenminste HBO-opleiding } \\ 4 & \text { elke academische opleiding } \\ 5 & \text { uw of een verwante academische opleiding } \\ 6 & \text { uw academische opleiding ongeacht specialistie } \\ 7 & \text { uw academische opleiding met uw specialisatie }\end{array}$

26. Heeft $u$ thans een leidinggevende functie? Zo ja, aan hoeveel mensen geeft u leiding?

1 geen leidinggevende functie

2 leiding aan $1-4$ personen

$3 \quad$ leiding aan 5 - 9 personen

$4 \quad$ leiding aan $10-19$ personen

$5 \quad$ leiding aan $20-49$ personen

6 leiding aan 50 of meer personen 
27. Hoeveel bedraagt uw bruto inkomen per maand in uw huidige functie bij een volledige werkweek? (exclusief toeslagen voor overwerk, 13e maand en vakantie)

$\begin{array}{ll}1 & \text { minder dan f } 1.500,-- \\ 2 & \text { f } 1.500,-- \text { tot } f 2.000,-- \\ 3 & \text { f } 2.000,-- \text { tot f } 2.500,-- \\ 4 & \text { f } 2.500,-- \text { tot f } 3.000,-- \\ 5 & \text { f } 3.000,-- \text { tot f } 3.750,-- \\ 6 & \text { f } 3.750,-- \text { tot } f 5.000,-- \\ 7 & \text { f } 5.000,-- \text { tot f } 7.500,-- \\ 8 & \text { f } 7.500,-- \text { tot } f 12.500,-- \\ 9 & \text { f } 12.500,-- \text { of meer }\end{array}$

28. Wat voor soort produkt of dienst wordt door de organisatie waar u werkt geleverd? (eventueel nader omschrijven)

naam dienst/produkt:

29. In wat voor een soort instelling, praktijk of bedrijf bent $u$ thans werkzaam? Op het inlegvel vindt $u$ een schema van branchegroepen, met de bijbehorende codenummers, zoals die door het CBS worden gehanteerd. Noteer hieronder het codenummer dat correspondeert met de diensten, c.q. produkten die door de instelling, de praktijk of het bedrijf waar u werkzaam bent worden geleverd.

codenummer branchegroep:

30. Hoeveel mensen werken er bij uw instelling, praktijk of bedrijf? Het gaat om de vestiging waar $u$ werkzaam bent.

$\begin{array}{ll}1 & \text { minder dan } 10 \text { personen } \\ 2 & 10 \text { tot en met } 49 \text { personen } \\ 3 & 50 \text { tot en met } 99 \text { personen } \\ 4 & 100 \text { personen of meer }\end{array}$

31. Wat is de naam, adres, postcode en plaats van de instelling, de praktijk of het bedrijf waar of van waaruit u werkt? Het gaat om de vestiging waar u op dit moment werkzaam bent.

naam

adres

postcode en plaats:

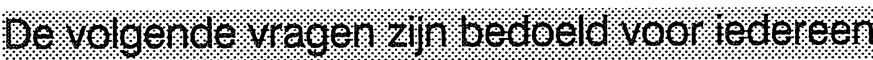

32. Bent u op dit moment op zoek naar een (andere) betaalde baan voor uzelf?

$\begin{array}{ll}1 & \text { ja } \\ 2 & \text { nee }\end{array}$

33. Bent $u$ als werkzoekende bij een arbeidsbureau ingeschreven?

$\begin{array}{ll}1 & \text { ja } \\ 2 & \text { nee }\end{array}$


De volgende vraag is uitsluitend bestemd voor degenen die betaald werk zoeken en op dit moment geen betaald werk verrichten

34. Als u nu een geschikte baan zou vinden, kunt $\mathrm{u}$ dan binnen 2 weken beginnen?

$\begin{array}{ll}1 & \text { ja } \\ 2 & \text { nee }\end{array}$

\section{Aanwulend onderwis}

35. Heeft u ná uw doctoraalexamen economie nog een opleiding of cursus gevolgd? Indien u meerdere opleidingen/cursussen volgt (heeft gevolgd), geeft $u$ het niveau, de richting en de naam aan van de opleiding/cursus met het grootste aantal lesuren. Het niveau en de richting kunt $u$ aangeven door de juiste codenummers te omcirkelen. Indien $u$ na het doctoraalexamen géén opleiding/cursus heeft gevolgd, omcirkel dan bij het niveau het cijfer 0 en bij de richting de cijfers 000 .

$$
\text { niveau: } \quad \begin{array}{ll}
0 & =\text { geen verder onderwijs } \\
1 & =\text { middelbaar beroepsonderwijs } \\
2 & =\text { hoger beroepsonderwijs } \\
3 & =\text { wetenschappelijk onderwijs, eerste fase } \\
4 & =\text { tweede fase onderwijs, bijv. AlO/OIO-opleiding } \\
5 & =\text { post-doctorale (beroeps)opleiding } \\
6 & =\text { post-academische cursussen } \\
7 & =\text { een ander soort opleiding of cursus }
\end{array}
$$

richting: $\quad 000=$ geen verder onderwijs

611 = economisch, namelijk:

612 = bedrijfskunde/ management, namelijk:

$613=$ administratief, namelijk:

$614=$ commercieel, namelijk:

999 = overig, richting:

naam van de opleiding/cursus:

(bijvoorbeeld: post-doctorale opleiding tot Controller)

\section{Tot sior}

36. Hieronder staan enkele activiteiten die voor afgestudeerden van de RL (mogelijk) worden georganiseerd. Omcirkel de aktiviteiten waarvoor u belangstelling heeft.

Meerdere antwoorden zijn mogelijk.

0 geen van onderstaande activiteiten

1 themadag voor afgestudeerde economen

2 voorlichting geven aan studenten economie over praktijk na afstuderen

3 reünie van jaar- en/of studiegenoten

4 post academisch onderwijs voor economen, namelijk:

5 opname in sollicitantenbestand

6 notatie in jaarlijkse adressenlijst voor afgestudeerde economen

7 tijdschrift voor afgestudeerden van de RL 
37. Wenst $u$ een samenvattend verslag van het onderzoek te ontvangen?

1 ja

2 nee

\section{Hartelijk dank voor uw medewerking!}

\section{Eventuele opmerkingen:}




\section{BEROEPSGROEPEN ECONOMEN}

codenummer beroepsgroep

0281

bedrijfsorganisatiedeskundige

0901

0902

0903

0904

0905

1101

1102

1103

1104

3314

1316

\section{ECONOMEN}

economist, (bedrijfs)econoom, sociaal-economisch onderzoeker economisch adviseur (nijverheidsconsulent, beleggingsadviseur e.d.) marketing-specialist assistent-econoom marketing-assistent

\section{ACCOUNTANTS}

accountant (accountantsbureau) accountant-administratieconsulent bedrijfs/rijksaccountant belastingconsulent assistent-accountant/controller

docent aan onderwijsinstelling

HOGERE LEIDINGGEVENDE FUNCTIES (NIET BIJ OPENBAAR BESTUUR, HANDEL, HORECA EN LANDBOUW)

hoofd afdeling interne administratie, financiële zaken e.d., bijv. administratief manager, economisch adjunct-directeur ziekenhuis, ziekenhuiseconoom hoofd afdeling verkoop, marketing, public relations e.d., bijv. brand-manager, commercieel manager, exportmanager, salesmanager

beleidsmedewerker

\section{ADMINISTRATIEVE FUNCTIES}

uitvoerend hoofdambtenaar belastingzaken, financiën e.d.

kostprijs/begrotingscalculator middelbare en hogere bankemployé, bijv. accountmanager, beleggings/ kredietadviseur, chef financiering/kredietverlening bijkantoorhouder bank lagere bankemployé, bijv. kredietadministrateur belastingambtenaar/assistent

\section{COMMERCIËLE FUNCTIES}

bedrijfsleider groothandel en tussenhandel, bijv. salesmanager, exportmanager bedrijfsleider detailhandel, bijv. rayonleider, verkoopleider makelaar/commissionair in roerende goederen makelaar in onroerend goed 


\section{BRANCHEGROEPEN ECONOMEN}

codenummer branchegroep

2000

INDUSTRIE

8100

BANK- EN VERZEKERINGSWEZEN

8200

bankwezen

verzekeringswezen (excl. wettelijke sociale verzekeringsorganen)

\section{ZAKELIJKE DIENSTVERLENING}

accountantsbureaus (academisch en nivra-niveau)

boekhoudbureaus en administratiekantoren

belastingadviesbureaus

marktanalyse- en opinie-onderzoekbureaus

statistische onderzoekbureaus t.b.v. het bedrijfsleven (excl. marktanalysebureaus)

public-relations adviesbureaus

bedrijfseconomische en bedrijfsorganisatorische adviesbureaus

OPENBAAR BESTUUR, WETTELIJKE SOCIALE VOORZIENING

algemeen overheidsbestuur bijv. gemeenten

belastingkantoren

wettelijke sociale verzekeringsorganen

ziekenfondsen

\section{ONDERWIJSINSTELLINGEN}

scholen voor algemeen voortgezet onderwijs scholen voor lager en middelbaar beroepsonderwijs instellingen voor hoger beroepsonderwijs universiteiten

\section{BEDRIJFS- EN WERKNEMERSORGANISATIES}

kamers van koophandel en fabrieken

werkgevers- en ondernemersorganisaties

werknemersorganisaties 